Conservation -

Division of Buildings and

Community Systems

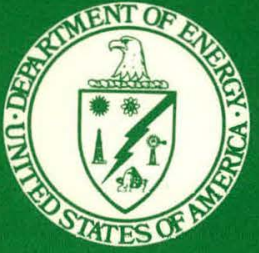

\section{Engineering-Economic Analysis of Single-Family Dwelling Thermal Performance}

\author{
Paul F. Hutchins, Jr.
}

Eric Hirst 


\section{DISCLAIMER}

This report was prepared as an account of work sponsored by an agency of the United States Government. Neither the United States Government nor any agency Thereof, nor any of their employees, makes any warranty, express or implied, or assumes any legal liability or responsibility for the accuracy, completeness, or usefulness of any information, apparatus, product, or process disclosed, or represents that its use would not infringe privately owned rights. Reference herein to any specific commercial product, process, or service by trade name, trademark, manufacturer, or otherwise does not necessarily constitute or imply its endorsement, recommendation, or favoring by the United States Government or any agency thereof. The views and opinions of authors expressed herein do not necessarily state or reflect those of the United States Government or any agency thereof. 


\section{DISCLAIMER}

Portions of this document may be illegible in electronic image products. Images are produced from the best available original document. 
Printed in the United States of America. Available from National Technical Information Service

U.S. Department of Commerce 5285 Port Royal Road, Springfield, Virginia 22161

Price: Printed Copy $\$ 5.25$; Microfiche $\$ 3.00$

This report was prepared as an account of work sponsored by an agency of the United States Government. Neither the United States Government nor any agency thereof, nor any of their employees, contractors, subcontractors, or their employees, makes any warranty, express or implied, nor assumes any legal liability or responsibility for any third party's use or the results of such use of any information, apparatus, product or process disclosed in this report, nor represents that its use by such third party would not.infringe privately owned rights. 
Contract No. W-7405-eng-26

ENERGY DIVISION

ENGINEERING-ECONOMIC ANALYSIS OF SINGLE-FAMILY DWELLING THERMAL PERFORMANCE

Paul F. Hutchins, Jr.

Eric Hirst

Date Published: November 1978

Department of Finergy

Office of Conservation and Solar Applications and

Energy Information Administration

OAK RIDGE NATIONAL LABORATORY

Oak Ridge, Tennessee 37830

operated by

UNION CARBIDE CORPORATION

for the

DEP ARTMENT OF INEISYY 
THIS PAGE

\section{WAS INTENTIONALLY \\ LEFT BLANK}


Various levels of investment in energy-efficient designs are analyzed for new single-family detached dwellings. The purpose is to develop relationships between initial cost and annual energy savings in space heating and cooling for use in the ORNL residential energy use simulation model. The analysis is performed for a $1200 \mathrm{ft}^{2}$ ranch-style home in nine U.S. locations using both natural gas or electricity. The annual loads calculation and cost surveys are based on a report by Petersen at the National Bureau of Standards, which used the NBSLD computer code. The economic analyses, which minimize lifecycle costs, were conducted using an updated version of a computer program written at ORNL.

Results define relationships between annual energy savings in space heating and cooling versus additional initial cost, which demonstrate the law of diminishing marginal returns. Curve characteristics are generally a function of climate, although the order of implementation for the various energyconserving options (heating only) is basically constant across all regions. Potential reductions in annual energy use range from 30 to $60 \%$ when compared to the present 1974 Housing and Urban Development Minimum Property Standards (HUD-MPS).

Optimum levels of investment in energy-conserving design for heating only were computed for each location. When compared to the 1974 HUD-MPS, major differences were noted for all but the natural gas-heated homes in areas less than 5200 heating degree days. Paybacks for additional investment above the current standard range from 15 to 20 years for natural gas users and four to six years for electricallyheated homes. 
THIS PAGE

\section{WAS INTENTIONALLY LEFT BLANK}


CONTENTS

Page

ABSTRACT . . . . . . . . . . . . . . . . . . . . $i$. . . .

1. INTRODUCTION . . . . . . . . . . . . . . . . . . . 1

2. DEFINITION OF SINGLE-FAMILY DWELLING . . . . . . . . . . . 4

Description . . . . . . . . . . . . . . . . . 4

Locations . . . . . . . . . . . . . . . . . 7

3. ANNUAL HEATING AND COOLING LOADS . . . . . . . . . . . . . 9

4. ECONOMIC ANALYSIS . . . . . . . . . . . . . . . . . 9

5. RESULTS AND INTERPRETATION . . . . . . . . . . . . . . 12

Thermal Analysis.. . . . . . . . . . . . . . . . . 12

Economic Analysis . . . . . . . . . . . . . . . . . . 15

Sensitivity Analysis . . . . . . . . . . . . . . . 23

6. SUMMARY AND CONCLUSIONS . . . . . . . . . . . . . . 26

ACKNOWLEDGMENTS . . . . . . . . . . . . . . . . . . . 27

REFERENCES . . . . . . . . . . . . . . . . . . . . 29

APPENDIX: Analysis Results for all Locations . . . . . . . . . 31 


\section{ENGINEERING-ECONOMIC ANALYSIS OF \\ SINGLE-FAMILY DWELLING THERMAL PERFORMANCE}

Paul F. Hutchins, Jr.

Eric Hirst

\section{INTRODUCTION}

This report analyzes different levels of investment in energyefficient designs for new single-family detached dwellings. The purpose is to define relationships between annual energy use for home space heating/cooling and initial investment in the structure shell for a range of climates in the United States. These relationships are then used to define the "optimum" design configuration for single-family homes in each location. The optimum is defined as the destgn configuration that minimizes the lifecycle cost of home purchase plus space heating and conling operating costs. Because of differences in climate, the optimum differs from location to location.

This study is similar to our earlier evaluation of the thermal performance of mobile homes. The methodology established and discussed in detail in the mobile home report ${ }^{l}$ will be used in this study.

The results will be incorporated into the Oak Ridge National Laboratory (ORNL) residential energy use simulation model. ${ }^{2}$ This simulation mnde1, developed for the Department of Energy, is being used to evaluate national and regional energy consumption and economic effects of various energy conservation policies, programs, and technologies.

Results of this analysis should also be useful to government policymakers involved with development of thermal performance standards. Title III of the Energy Conservation and Production Act of $1976^{3}$ requires development and implementation of new standards "to achieve maximum practicable improvements in energy efficiency." The methodology used here allows selection of energy-efficient designs based on not only thermodynamics and heat transfer, but also economics for a variety of circumstances. This allows for more flexible standards sensitive to the economic and climatic conditions of the location. 
The residential sector accounts for a significant portion of United States primary energy use (about twenty percent). Space heating and. cooling represent about 55 and five percent, respectively, of sector fuel use. ${ }^{4}$ Single-family detached housing accounts for about 50 percent of all new residential construction each year, and about 65 percent of the existing housing stock. ${ }^{5}$ Each year slightly more than one million new single-family detached homes are constructed. Table 1 shows the distribution and growth patterns of single-family homes between 1970 and 1975 for census regions and divisions.

Table 1. Existing households in single-family detached dwellings

\begin{tabular}{|c|c|c|c|c|}
\hline \multirow{2}{*}{ Locations } & \multicolumn{4}{|c|}{ Occupied homes (millions)* } \\
\hline & 1970 & 1973 & 1974 & 1975 \\
\hline $\begin{array}{l}\text { Northeast } \\
\text { New England } \\
\text { Middle Atlantic }\end{array}$ & $\begin{array}{ll}7.78 & (17) \\
2.11 & (5) \\
5.66 & (13)\end{array}$ & $8.30(17)$ & $8.32(17)$ & $8.4(17)$ \\
\hline $\begin{array}{l}\text { North Centra1 } \\
\text { East North Central } \\
\text { West North Central }\end{array}$ & $\begin{array}{cc}13.3 & (30) \\
9.03 & (20) \\
4.24 & (9)\end{array}$ & $13.8 \quad(29)$ & $13.9 \quad(29)$ & $14.2(29)$ \\
\hline $\begin{array}{l}\text { South } \\
\text { South Atlantic } \\
\text { East S. Central } \\
\text { West S. Central }\end{array}$ & $\begin{array}{rr}15.7 & (35) \\
7.08 & (16) \\
3.37 & (8) \\
5.24 & (12)\end{array}$ & $17.1 \quad(36)$ & $17.2 \quad(36)$ & $17.8(36)$ \\
\hline $\begin{array}{l}\text { West } \\
\text { Mountain } \\
\text { Pacific }\end{array}$ & $\begin{array}{l}8.08(18) \\
1.97(4) \\
6.11(14)\end{array}$ & $8.70(18)$ & $8.86(18)$ & $9.1(18)$ \\
\hline United States Total & $44.8(100)$ & $47.9(100)$ & $48.2(100)$ & $49.5(100)$ \\
\hline
\end{tabular}


Because single-family detached homes represent such a large portion of the U.S. housing stock, thermal standards should be economically defined to minimize home purchase and operating costs. In the past, thermal standards were based on judgments by representatives of home builders and government personnel. This absence of detailed analysis makes existing thermal standards economically inadequate for future buildings because of rising fuel prices.

The methodology used in this study is shown schematically in

Fig. 1. Annual and peak heating and cooling loads for the dwelling were calculated using a thermal loads computer code called NBSLD 6 (National Bureau of Standards Loads Determination). These results plus design option cost and other economic parameters (interest rates, fue 1 costs, property tax, insurance rates, etc.) are inputs to the Economic Analysis Program (EAP). Various inputs are combined with EAP to yield two basic results: the relationship between annual energy load and additional initial investment in energy conserving design and the optimal design that minimizes lifecycle costs for each location.

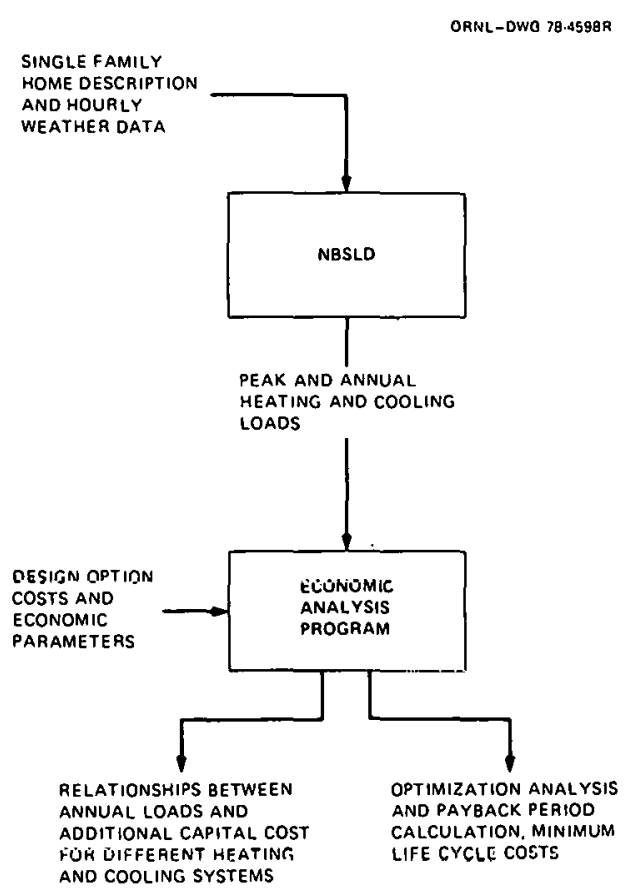

Fig. 1. Schematic of analytical methodology. 
All results generated by the NBSLD program were provided by Petersen ${ }^{7}$ at the National Bureau of Standards (NBS). Petersen combined these results with appropriate cost data to define the most cost-effective order of implementation for the various design options. The objective of this study is, therefore, to present and evaluate the annual load versus cost relationships for use in the ORNL residential energy use simulation model and perform an optimization analysis for each location.

\section{DEFINITION OF SINGLE-FAMILY DWELLING}

\section{$\underline{\text { Description }}$}

The single-family residence studied by Petersen is a $1200 \mathrm{ft}^{2}$ single-story ranch-style house over a vented crawlspace. Important envelope area parameters are listed in Table $2 .{ }^{7}$ The basic dimensions of the residence were chosen to be representative of new house construction. 8

Table 2. Single-family dwelling envelope parameters

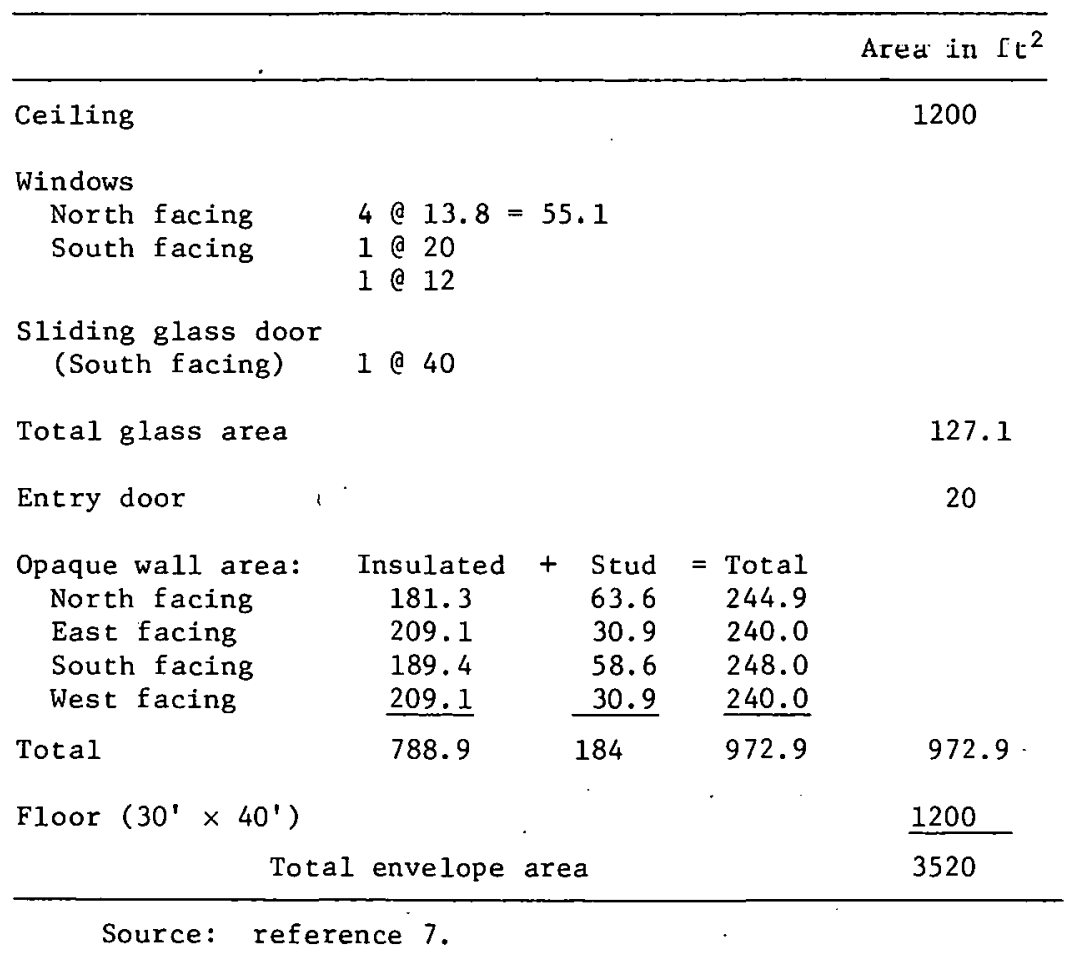


The baseline wall construction is $2 \times 4$ studs on $24^{\prime \prime}$ centers with no insulation. All windows are single-pane. This baseline design has slightly less thermal protection than was required by the 1965 U.S. Department of Housing and Urban Development Minimum Property Standards for One and Two Family Dwellings (HUD-MPS).

The house is oriented so that a vector normal to the longer wall faces due north. Fifty percent shading of windows (to represent curtains) is assumed during cooling operations. Sensitivity of heating and cooling loads to both orientation and shading is discussed in section 5.

The minimum and maximum indoor temperatures are assumed to be 68 and $78^{\circ} \mathrm{F}$ for heating and cooling, respectively, with no night setback.* More detailed information on the single-family house construction characteristics is in ref. 7 .

The design options studied include only those currently available to the consumer in new housing construction. These options are permanent and passive and do not affect occupant lifestyle. The improvements considered are:

1. additional insulation in walls, ceiling, and floor

2. multi-pane windows

3. multi-pane sliding glass door

4. storm door

5. six-inch insulated walls

6. styrofoam wall sheathing

Costs for each design option are from information provided by the National Association of Home Builders. 10 Figures include dealer mark-up and represent the U.S. average cost to the consumer. Local price variations. are evaluated later in Section 4. The costs (adjusted irom 1977 to 1975 dollars) represent the incremental expense to the consumer as a

\footnotetext{
"Petersen evaluated the effects of night setback on each conservation option in Washington, D.C. His results show that the effects of setback are essentially independent of structure thermal performance. For the other cities, Petersen assumed night setback for each option; he also evaluated one option in each city with a constant winter thermostat setting of $68^{\circ} \mathrm{F}$. We used the ratio of heating loads with and without setback for that option in each city to adjust Petersen's results for constant winter thermostat setting.
} 
result of purchasing a single-family home with energy-efficient options in addition to those present in the baseline configuration. These costs are listed in Table 3.

As the thermal integrity of the building shell is improved, heating and cooling equipment capacities needed to meet the design (or peak) load become smaller. Reference 10 provides cost information necessary to account for savings due to HVAC (heating, ventilation, and air conditioning) equipment size reductions. The average incremental cost (1975 dollars) to the consumer for gas and electric heating furnaces is $\$ 2.60 / \mathrm{kBtu} / \mathrm{hr}\left(\mathrm{kBtu}=10^{3} \mathrm{Btu}\right)$ and $\$ 2.10 / \mathrm{kBtu} / \mathrm{hr}$ output, respectịely.

Table 3. Design option cost data

\begin{tabular}{|c|c|c|c|c|}
\hline \multirow{2}{*}{ Item } & \multirow{2}{*}{$\begin{array}{c}\text { Average unit } \cos t^{*} \\
(1975-\$)\end{array}$} & \multirow{2}{*}{ Amount } & \multicolumn{2}{|c|}{$\begin{array}{l}\text { Additional costs } \\
(1975-\$)\end{array}$} \\
\hline & & & Labor on $1 y$ & Total \\
\hline $\begin{array}{l}\text { Wa11 insulation } \\
\begin{array}{l}0 \rightarrow \mathrm{R}-11 \\
\mathrm{R}-11 \rightarrow \mathrm{R}-13 \\
\mathrm{R}-13 \rightarrow \mathrm{R}-19 \S \\
\mathrm{R}-19 \rightarrow \mathrm{R}-23^{\text {\# }}\end{array}\end{array}$ & $\begin{array}{l}13.4 \mathrm{c} / \mathrm{ft}^{2 \dagger} \\
4.5 \mathrm{f} / \mathrm{ft}^{2} \\
17.8 \mathrm{f} / \mathrm{ft}^{2} \\
17.8 \mathrm{f} / \mathrm{ft}^{2}\end{array}$ & $\begin{array}{l}1120 \mathrm{ft}^{2+} \\
1120 \mathrm{ft}^{2} \\
1120 \mathrm{ft}^{2} \\
1120 \mathrm{ft}^{2}\end{array}$ & $\begin{array}{r}40 \\
0 \\
40 \\
60\end{array}$ & $\begin{array}{r}150 \\
50 \\
200 \\
200\end{array}$ \\
\hline $\begin{array}{c}\text { Attic insulation } \\
0 \rightarrow \mathrm{R}-11 \\
\mathrm{R}-11 \rightarrow \mathrm{R}-19 \\
\mathrm{R}-19 \rightarrow \mathrm{R}-30 \\
\mathrm{R}-30 \rightarrow \mathrm{R}-38 \\
\mathrm{R}-38 \rightarrow \mathrm{R}-49\end{array}$ & $\begin{array}{l}13.4 c / \mathrm{ft}^{2} \\
6.2 \mathrm{c} / \mathrm{ft}^{2} \\
9.8 \mathrm{c} / \mathrm{ft}^{2} \\
6.2 \mathrm{c} / \mathrm{ft}^{2} \\
9.8 \mathrm{c} / \mathrm{ft}^{2}\end{array}$ & $\begin{array}{l}1200 \mathrm{ft}^{2} \\
1200 \mathrm{ft}^{2} \\
1200 \mathrm{ft}^{2} \\
1200 \mathrm{ft}^{2} \\
1200 \mathrm{ft}^{2}\end{array}$ & $\begin{array}{r}4.3 \\
0 \\
0 \\
0 \\
0\end{array}$ & $\begin{array}{r}160 \\
75 \\
117 \\
75 \\
117\end{array}$ \\
\hline $\begin{array}{l}\text { F1oor insulation } \\
0 \rightarrow \mathrm{R}-11 \\
\mathrm{R}-11 \rightarrow \mathrm{R}-19\end{array}$ & $\begin{array}{r}16.0 \mathrm{c} / \mathrm{ft}^{2} \\
\text { 7. } 1 \mathrm{c} / \mathrm{ft}^{2}\end{array}$ & $\begin{array}{l}1200 \mathrm{ft}^{2} \\
1200 \mathrm{ft}^{2}\end{array}$ & $\begin{array}{r}75 \\
0\end{array}$ & $\begin{array}{r}1.92 \\
85\end{array}$ \\
\hline $\begin{array}{l}\text { Glazing } \\
\text { Double } \\
\text { Triple }\end{array}$ & $\begin{array}{l}\$ 1.78 / \mathrm{ft}^{2} \\
\$ 2.00 / \mathrm{ft}^{2}\end{array}$ & $\begin{array}{l}87 \mathrm{ft}^{2} \\
87 \mathrm{ft}^{2}\end{array}$ & $\begin{array}{l}36 \\
36\end{array}$ & $\begin{array}{l}155 \\
174\end{array}$ \\
\hline $\begin{array}{l}\text { Door } \\
\text { Storm } \\
\text { Double glazed } \\
\text { sliding glass }\end{array}$ & $\begin{array}{l}\$ 2.69 / \mathrm{ft}^{2} \\
\$ 3.12 / \mathrm{ft}^{2}\end{array}$ & $\begin{array}{l}20 \mathrm{ft}^{2} \\
40 \mathrm{ft}^{2}\end{array}$ & 31 & $\begin{array}{l}107^{\|} \\
125\end{array}$ \\
\hline $\begin{array}{l}{ }^{*} \text { Includes lab } \\
\text { † Gross area, } \\
{ }_{\text {R-19 plus st }} \\
{ }^{\ddagger} \text { Includes add } \\
{ }^{*} \text { Three doors, } \\
\text { Source: refe }\end{array}$ & $\begin{array}{l}\text { cost. } \\
\text { cludes windows and } \\
\text { ofoam sheathing. } \\
\text { ional cost for } 2 \times 6 \\
\text { ach with a ten year } \\
\text { nce } 7 \text {. }\end{array}$ & $\begin{array}{l}\text { oors. } \\
\text { tuds. } \\
\text { life, disco }\end{array}$ & ted to pre & \\
\hline
\end{tabular}


For air conditioning the incremental cost is $\$ 23 / \mathrm{kBtu} / \mathrm{hr}$ output.*

Both the cases of heating only and heating plus cooling are evaluated.

The heating fuel choices in new single-family housing in 1975-1976

for the nine Census divisions are shown in Table 4.11 Electricity

represents half of the U.S. total, gas (mostly natural gas) 43\%, and oil

Table 4. Distribution of heating fuels for new singlewfamily detached hores, 1975-1976

\begin{tabular}{|c|c|c|c|c|c|c|c|c|c|c|}
\hline $\begin{array}{l}\text { Heating fuel } \\
\text { source }(\chi)\end{array}$ & $\begin{array}{l}\text { New } \\
\text { England }\end{array}$ & $\begin{array}{c}\text { Mid } \\
\text { Atlantic }\end{array}$ & $\begin{array}{c}\text { East North } \\
\text { Central }\end{array}$ & $\begin{array}{c}\text { West North } \\
\text { Central }\end{array}$ & $\begin{array}{c}\text { South } \\
\text { Atlant } 1 c^{*}\end{array}$ & $\begin{array}{c}\text { East South } \\
\text { Central }\end{array}$ & $\begin{array}{c}\text { West South } \\
\text { Central }\end{array}$ & Mountaln & Pacific & $\begin{array}{l}\text { U.S. } \\
\text { Total }\end{array}$ \\
\hline Gas & 19 & 18 & 49 & 72 & 16 & 29 & 38 & 61 & 61 & 43 \\
\hline Electric & 32 & 51 & 48 & 26 & 76 & 71 & 62 & 39 & 39 & 50 \\
\hline 011 & 49 & 31 & 3 & 2 & 7 & $\dot{0}$ & 0 & 0 & 0 & 7 \\
\hline
\end{tabular}

*about $1 \%$ of new homes in the South Atlantic division are solar heated.

Source: reference 11 .

the remainder. Oil dominates only in New England, while electricity and gas are popular in all other areas. Because of their widespread use, natural gas and electricity are selected for study here. However, the results for natural gas can be used for oil by substituting the appropriate fuel price and combustion efficiency.

\section{Locations}

Nine of the cities selected for study by Petersen are shown in Figure 2 and listed in Table 5. These selections represent a wide range of climates among densely populated areas. Cities were chosen to represent climates similar to those used in the mobile home study. ${ }^{1}$ Seven locations are the same. Phoenix was substituted for San Diego. Fort Worth replaced Cheyenne to fill the gap between Miami and Atlanta cooling loads noticeable in the mobile home analysis. The particular weather data used for each city is the l'est Reterence Year ${ }^{12}$ recommended by ASHRAE (American Society of Heating, Refrigerating, and Air Conditioning Engineers). Detailed discussion on the site selection process is in ref. 7.

* These figures do not include labor costs. It is assumed that the HVAC systems are present in the baseline design to allow the size reductions and therefore involve no additional labor costs. 


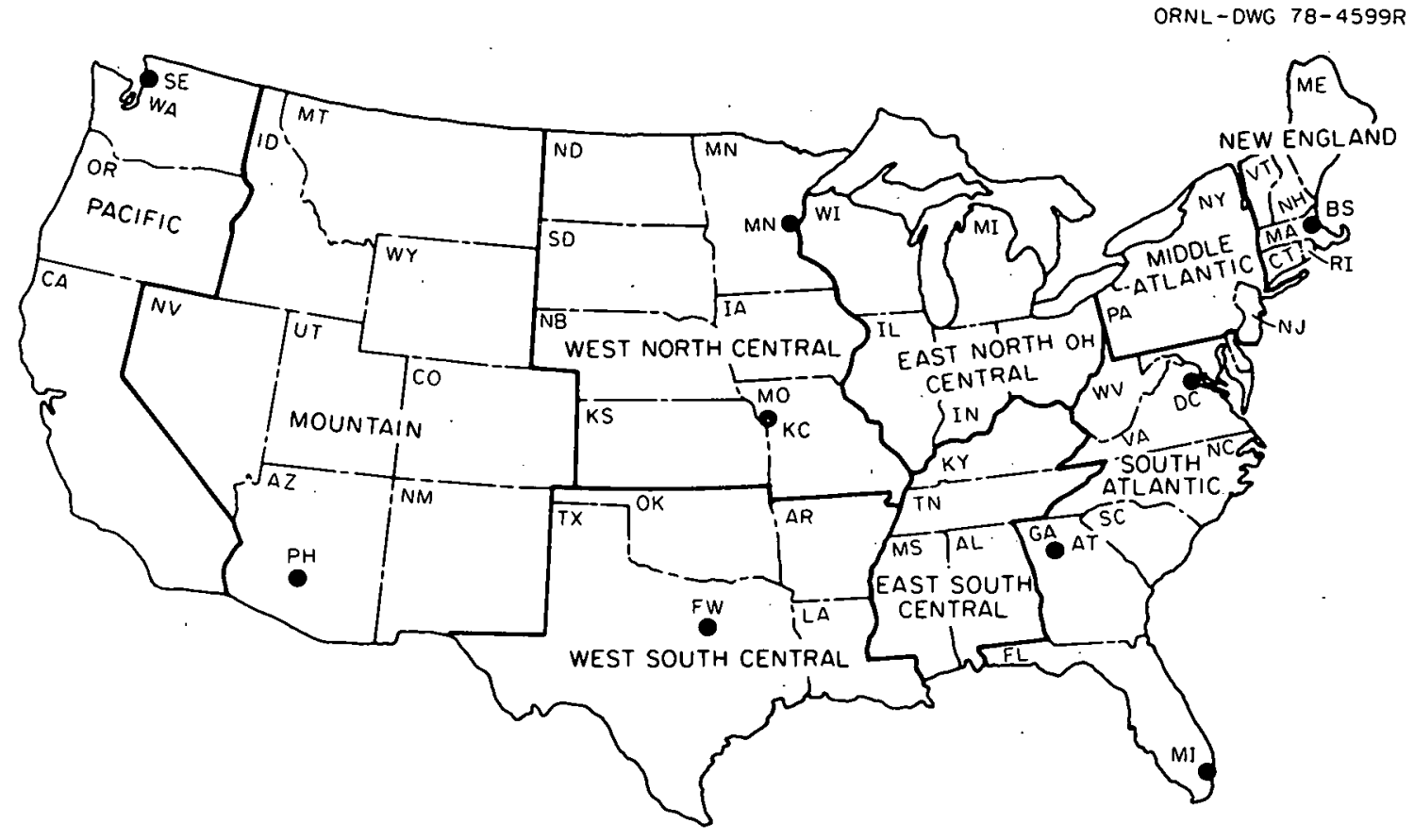

Fig. 2. Cities chosen for analysis.

Table 5. Weather data for cities selected

\begin{tabular}{llccc}
\hline & \multicolumn{1}{c}{ City } & $\begin{array}{c}\text { Weather tape } \\
\text { year }\end{array}$ & \multicolumn{2}{c}{$\begin{array}{c}\text { Annual degree days } \\
\left.\text { (Base } 65^{\circ} \mathrm{F}\right)\end{array}$} \\
\cline { 4 - 5 } & & 1970 & 8316 & 919 \\
\hline MN & Minneapolis & 1969 & 5781 & 667 \\
BS & Boston & 1960 & 5562 & 143 \\
SE & Seattle & 1968 & 5058 & 1485 \\
KC & Kansas City & 1957 & 4161 & 1482 \\
DC & Washington, D.C. & 1975 & 2959 & 1359 \\
AT & Atlanta & 1975 & 2373 & 2495 \\
FW & Fort Worth & 1951 & 1571 & 3434 \\
PH & Phoenix & 1964 & 130 & 4176 \\
MI & Miami & & &
\end{tabular}




\section{ANNUAL HEATING AND COOLING LOADS}

Heat flows through the shell of a single-family residence are extremely complicated. Such mechanisms as infiltration and heat storage make steady-state models unreliable. For this study a sophisticated computer code, NBSLD, was used to calculate the dynamic thermal response of a residence using hourly weather data tapes.

As stated earlier, all analyses necessary to produce the annual and peak heating and cooling loads were provided by Petersen at NBS. The NBSLD code was improved to account for hcat flows through the floor, and the output was expanded to provide a more useful research tool. Details on the updated NBSLD code are in ref. 13.

\section{ECONOMIC ANALYSIS}

The Economic Analysis Program performs three tasks:

1. Develops relationships between annual heating and cooling loads and additional investment in thermal improvements to the building she1l.

2. Computes the payback period and net present worth (using lifecycle cost analysis) of each design option to select the optimum.

3. Performs sensitivity analysis to determine the effects on above results of changes in input parameters (insurance and tax rates, fuel prices, interest rates, etc.).

Inputs include peak and annual heating and cooling loads, additional costs for each of the sixteen design options (Table 3), and other variable parameters that affect energy-related lifecycle costs; see Table 6 . The nominal value column represents typical values for each item in the U.S. These numbers vary from region to region as indicated by the range column values.

The material and labor indices represent cost factors relative to the average U.S. price. This factor is multiplied by the nominal design option or HVAC equipment price to account for regional price variations. The effects of changes in property taxes and income tax deductions are also included. The real interest rate is the cost of borrowed money for 
Table 6. Values of energy-related parameters

\begin{tabular}{|c|c|c|c|}
\hline & $\begin{array}{l}\text { Nominal } \\
\text { value }\end{array}$ & Range ${ }^{*}$ & Source \\
\hline Material cost index & 1.0 & $0.85-1.15$ & 14 \\
\hline Labor cost index & 1.0 & $0.85-1.15$ & 14 \\
\hline State property tax ( $\%$ of home value) & 2.5 & $1.0-6.0$ & 15 \\
\hline $\begin{array}{l}\text { Marginal federal income tax rate } \\
\text { (married filing jointly) }\end{array}$ & 0.25 & $0.22-0.28$ & \\
\hline $\begin{array}{l}\text { Marginal annual insurance premium } \\
(\% \text { of home value) }\end{array}$ & 0.4 & $\underline{0.2-0.8}$ & \\
\hline Annual real interest rate $(\%)$ & 5.0 & $2.0-11.0$ & \\
\hline Time horizon (years) & 30 & $25-\underline{35}$ & \\
\hline $\begin{array}{l}\text { Seasonal fuel utilization efficiency } \\
\text { Gas heating (\%) } \\
\text { Electric resistance heating (\%) } \\
\text { Air conditioning (EER) }\end{array}$ & $\begin{array}{r}60 \\
100 \\
7.0\end{array}$ & $\begin{array}{l}50-70 \\
100 \\
6.0-8.0\end{array}$ & $\begin{array}{l}16 \\
17\end{array}$ \\
\hline $\begin{array}{l}\text { Fuel prices }(\$ / M B t u)^{\neq} \\
\text {Natural gas } \\
\text { Electricity }\end{array}$ & $\begin{array}{r}2.00 \\
10.00\end{array}$ & $\begin{array}{l}1.00-\underline{16.00} \\
1.70-\underline{27.00}\end{array}$ & \\
\hline $\begin{array}{l}\text { *Underlined values are those th } \\
\text { conserving design options. } \\
{ }_{\text {EER }}=\text { energy efficiency ratio } \\
\text { hour used). } \\
\text { क Average } 1975 \text { fuel prices, MBtu } \\
\text { \$ To convert from } \$ / \mathrm{MBtu} \text { to } \mathrm{c} / \mathrm{kW}\end{array}$ & $\begin{array}{l}\text { ncourage } \\
\text { Btu of he } \\
0^{6} \text { Btu. }\end{array}$ & $\begin{array}{l}\text { estment in } \\
\text { removed per }\end{array}$ & rgy- \\
\hline
\end{tabular}

home financing minus inflation. The discount rate, used in the net present worth analysis is assumed to be equal to the real interest rate. The time horizon is equal to the loan term for this study.

The relationships between inputs and the Economic Analysis Program results are shown in Fig. 3: Peak loads from NBSLD plus incremental cost data for shell improvements and HVAC equipment size reductions are used to compute the additional initial cost for each design option. These are combined with the annual loads data from NBSLD to form the annual load versus additional cost relationships.

A net present worth (NPW) analysis is used to compare the costeffectiveness of different design options. The objective is to maximize 


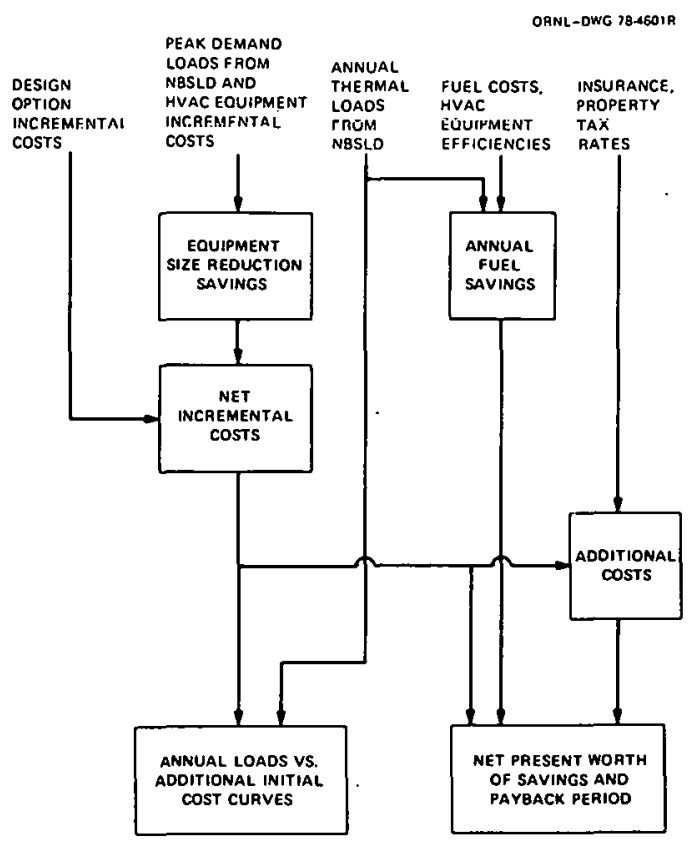

Fig. 3. Economic analysis program flowchart.

the net present worth of savings, which is the difference between the present worths of savings and costs. Additional costs incurred for each design option include the material and labor costs plus resulting increases in property tax and insurance premium. Annual fuel savings are due to reduced energy use as a result of design option additions.

The NPW for each design option is calculated using equations presented in Section IV of ref. 1, with a few changes: state sales tax is eliminated and savings due to federal income tar deductions ale included. Calculations show that savings due to income tax deductions of mortgage interest and property tax cancel almost exactly additional costs due to property tax and insurance premiums using nominal values in Table 6 . Therefore, the mobile home approach can be used for the single-family analysis by using zero state sales tax, insurance premium, and property tax. The NPW is calsulater in the same manner. The maximum value uf NPW among the various combinations of options for any location is the optimum.

Because economic parameter inputs used in the Economic Analysis Program vary significantly (see Table 6), it is neressary to evaluate their effect on the final result. The values in the range column of 
Table 6 are divided into two extremes - those that encourage investment in energy-conserving design and those that discourage the same. Values of each extreme are used independently to determine the maximum effects on the results. Other runs are made eliminating the variables which cause negligible changes, so that the important factors are discovered and evaluated.

\section{RESULTS AND INTERPRETATION}

Thermal Analysis

Many computer runs were made to determine the order in which the different design options (Table 3 ) should be added to obtain maximum cost-effectiveness. The most economical order of implementation depends not only on the ability of the design option to reduce energy consumption, but also on the additional initial expense to the consumer. Therefore, by combining results of thermal loads analysis and cost data from Table 3, the order for adding energy-efficient designs is determined. Since heating fuel bills dominate cooling in all but the mildest climates, the following order is based on heating only:*

1. Baseline

2. R-11 attic insulation

3. R-11 wall insulation

4. R-19 attic insulation

5. R-11 floor insulation

6. Storm windows

7. $\mathrm{R}-30$ attic insulation

8. $\mathrm{R}-19$ floor insulation

9. Double glazed sliding glass door (SGD)

10. R-13 wail insulation

11. R-38 attic insulation

12. R-19 wall insulation

13. Triple pane windows

14. R-49 attic insulation

15. Storm door

16. R-23 wall insulation (using styrofoam)

*Each step is cumulative, i.e., the decision to proceed from one step to the next is based on benefits and costs relative to those incurred from previous steps. 
NBSLD results for Kansas City are shown in Table 7 using the heatingonly order. Results for the other locations are in Appendix Tables A-l through A-9.

To demonstrate the relationship between climate and energy use, a graph of baseline annual heating and cooling loads versus heating and cooling degree days, respectively, is presented in Fig. 4. The identification codes for the locations in Fig. 4 and others to follow are in Table 5. Results demonstrating linear relationships ${ }^{*}$ between annual loads and degree days are similar to those found in other analyses.1,4 The equations that define the relationships in Fig. 4 are:

$$
\begin{aligned}
& \operatorname{AHL}(1) \approx 0.0171 \cdot \mathrm{HDD} \\
& \operatorname{ACL}(1) \approx 0.0110 \cdot \mathrm{CDD}
\end{aligned}
$$

where

$$
\begin{aligned}
& \operatorname{AHL}(1) \text { = annual heating load for baseline configuration (MBtu), } \\
& \text { HDD = annual number of heating degree days (base } 65^{\circ} \mathrm{F} \text { ), } \\
& \text { ACL }(1) \text { = annual cooling load for baseline configuration (MBtu), and } \\
& \mathrm{CDD}=\text { annual number of cooling degree days (base } 65^{\circ} \mathrm{F} \text { ). }
\end{aligned}
$$

\footnotetext{
*There is one notable exception to the linear relationships described in Fig. 4. The baseline cooling load for Phoenix (51.5 MBtu/year) is about 50 percent greater than would be predicted by the results from other U.S. locations. Investigations by Petersen ${ }^{7}$ show that for some locations the degree day calculation (computed by subtracting a reference temperature, in this case $65^{\circ} \mathrm{F}$, from the average of the daily high and Low temperatures) is not effective. When $65^{\circ} \mathrm{F}-\mathrm{plus}$ daytime temperatures are followed by sub $-65^{\circ} \mathrm{F}$ temperatures at night, there is a cancellation, and the cooling needed during the day does not affect the degree day total. Other complexities (such as variation in the percentage of latent to the total load) cause the cooling loads to be much less predictable than heating loads. However, the effects of these problems are minimized by the use of marginal analysis. In this method systematic errors are reduced by comparing absolute values and presenting results in terms of relative quantities.
} 
Table 7. NBSLD load calculation results - Kansas City

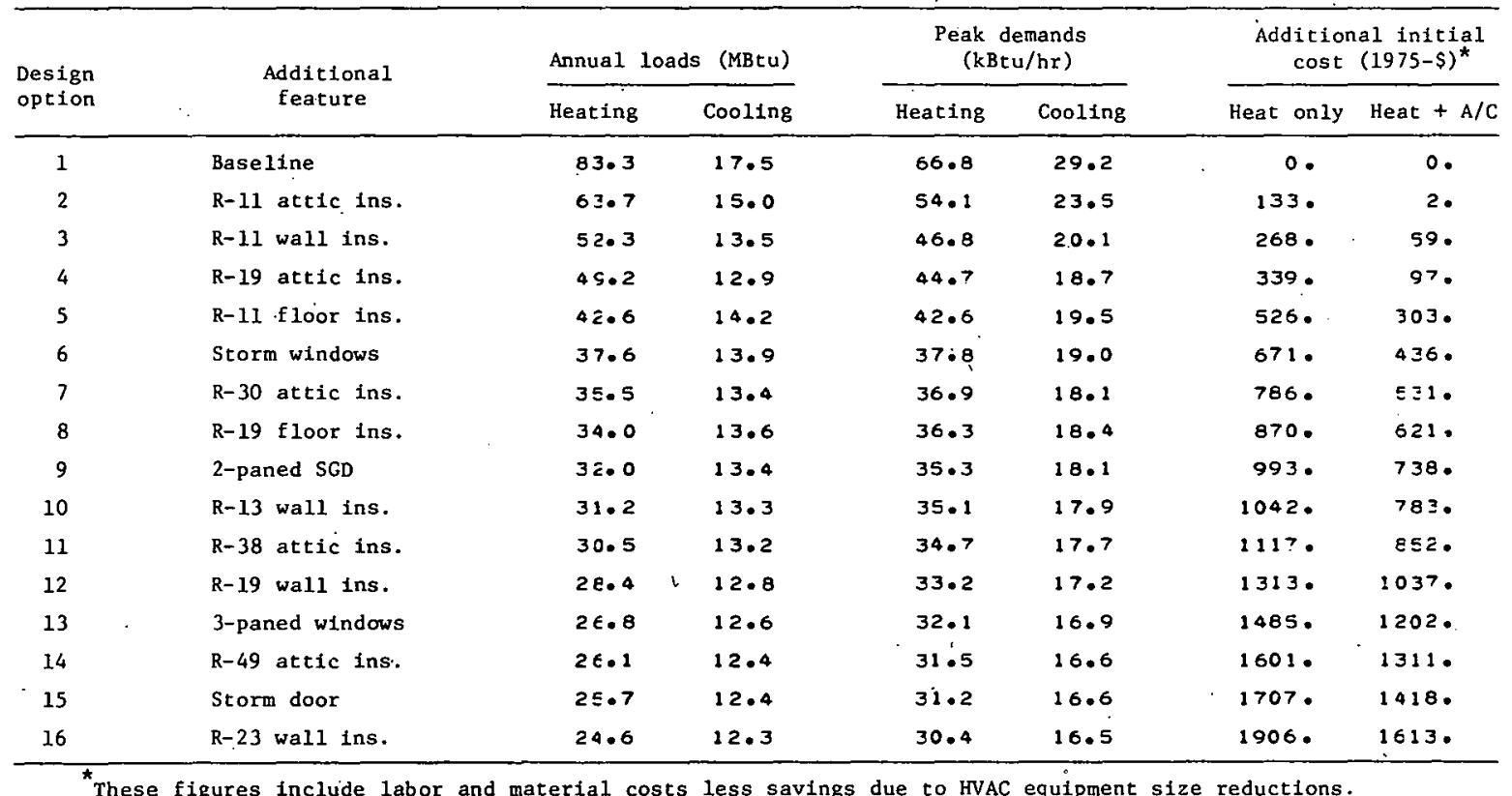

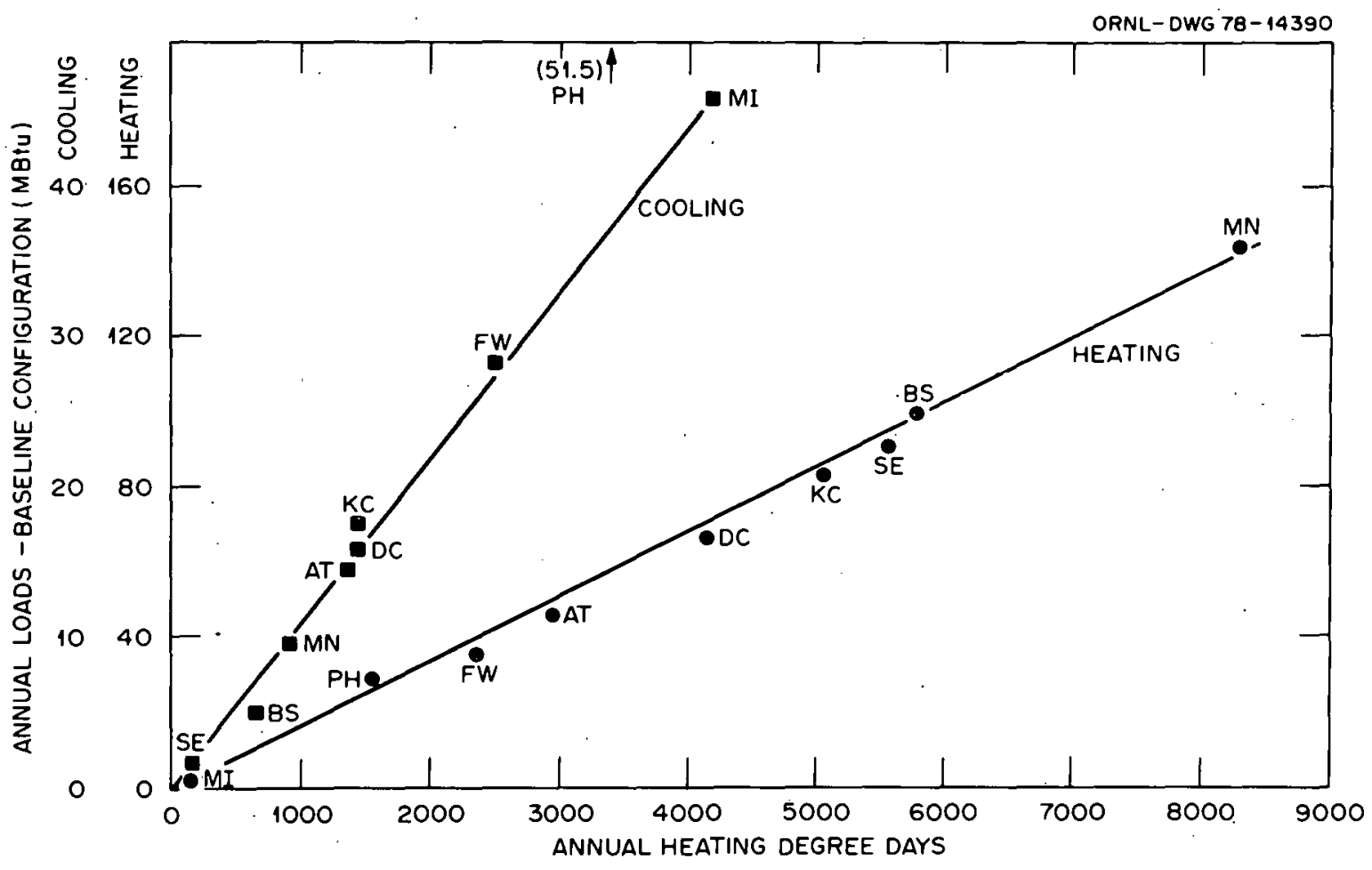

Fig. 4. Regional variation in annual baseline configuration loads. 
Dividing annual heating and cooling loads by the number of heating and cooling degree days, respectively, and by floor space, yields a figure of merit often discussed. ${ }^{4,18}$ For the baseline configuration these numbers are $14.3 \mathrm{Btu} / \mathrm{HDD} / \mathrm{ft}^{2}$ and $9.13 \mathrm{Btu} / \mathrm{CDD} / \mathrm{ft}^{2}$. These numbers are comparable to those in other documents.

Home orientation had insignificant effects on annual heating. This is expected because of the squareness of the residence design. During cooling hours, however, the annual heat gains on the east and west walls were 30 to $45 \%$ greater than those on the north and south. Therefore, cooling loads were minimized with respect to orientation by keeping the majority of the glass on the north-south walls of the house. Although not evaluated as a design option, awnings reduce annual cooling loads 10 to $25 \%$ when installed on snuth-facing windows. ${ }^{7}$ However, paybacks for this feature are greater than 15 years, even in the warmer climates. Properly designed roof overhang will yield similar results with shorter paybacks. Due to low sun angles in the morning and late afternoon, awnings are not as effective on east- and west-facing windows.

The effects of variation in window size on heating loads was investigated by Petersen. ${ }^{7}$ For single-glazing, windows are a net heat loss during the heating season in all locations. However, using design option 非1 (see Table 7), which includes double-pane windows, houses in the following cities showed a net heat gain through the windows during the winter: Kansas City, Boston, and Atlanta. Therefore, increasing window size to improve wintertime thermal performance of this characterist1c house is limited to only a few locations with storm windows. It should be noted, however, that this residence has very low heat storage capacity compared to houses of brick construction and was not designed to perform in a passive solar mode.

Economic Analysis

Annual heating loads for each option are normalized to the baseline configuration and graphed as a function of additional initial cost. Results for Kansas City are in Fig. 5. Graphs for each of the locations 


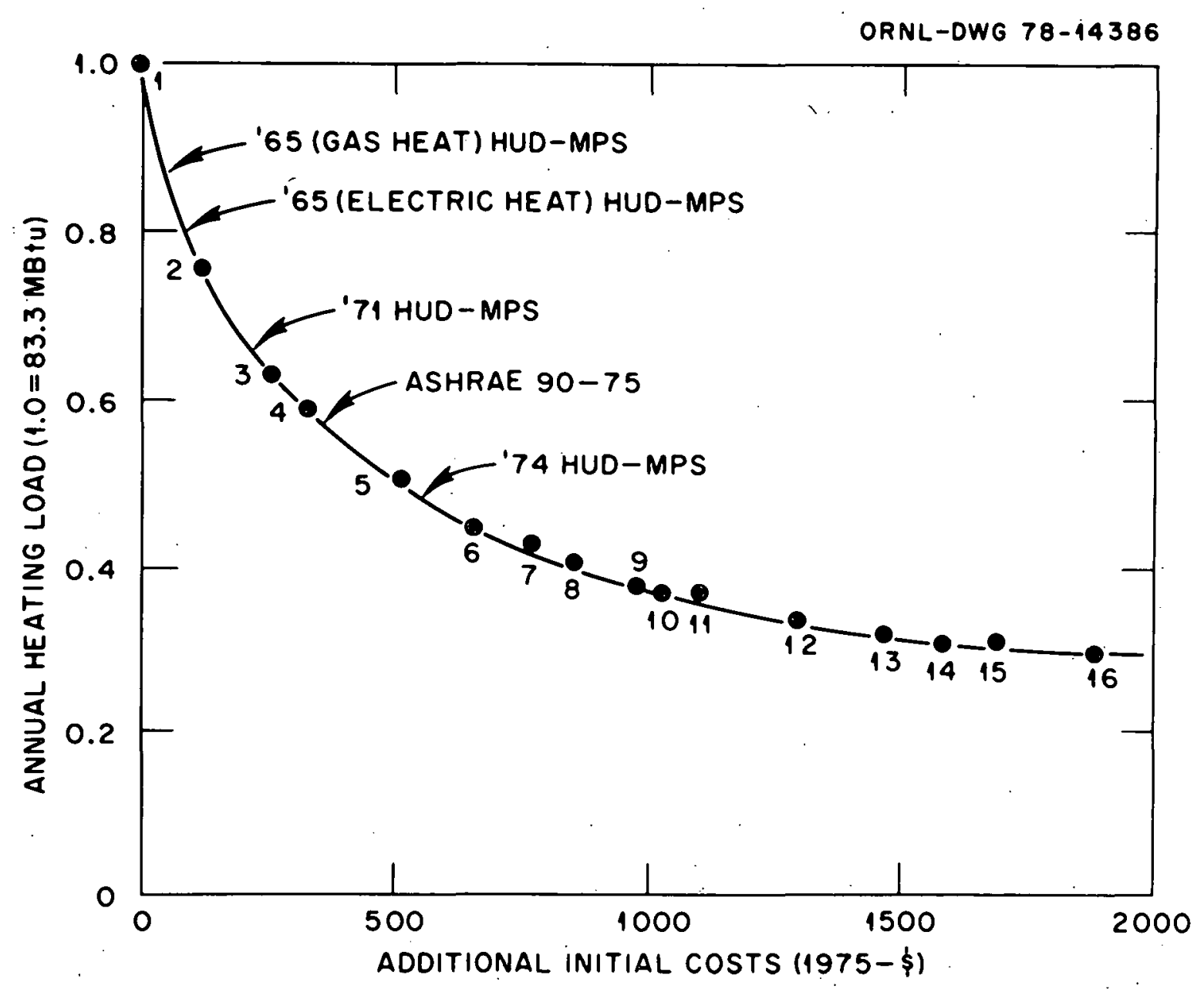

Fig. 5. Heating load/cost relationship - Kansas City

are in Appendix Figs. A-1 through A-9. The optimal order of the options varies little from location to location. The curve shape, similar for all locations, demonstrates the law of diminishing marginal returns.

Also shown on the heating load versus cost curves are approximate positions of past and present single-family thermal standards and guidelines. The amounts of insulation necessary to meet the HUD-MPS and ASHRAE Standard 90-75 were found in the literature. 19,20,21

To evaluate how the heating load versus additional cost curves (Figs. A-1 through A-9) vary by location, two curve characteristics are investigated. The initial slope $(K)$ is the slope of the load/cost curve at the baseline point. The asymptote $\left(T_{\infty}\right)$ is the annual load percentage 
value that the load/cost curve tends to approach as the additional initial cost increases toward infinity. The initial slope and terminal asymptote of the heating load/cost curves are plotted versus annual heating degree days for each location in Figs. 6 and 7, respectively. The initial negative slope is approximately a linear function of heating degree days:

$$
\mathrm{K} \approx 3.13 \mathrm{E}-5 \cdot \mathrm{HDD}+0.015
$$

where

$\mathrm{K}$ is MBtu saved per additional dollar invested (Fig. 6).

This result implies that energy savings per additional dollar invested are greater and the options are more cost-effective for cold than for warm climates.

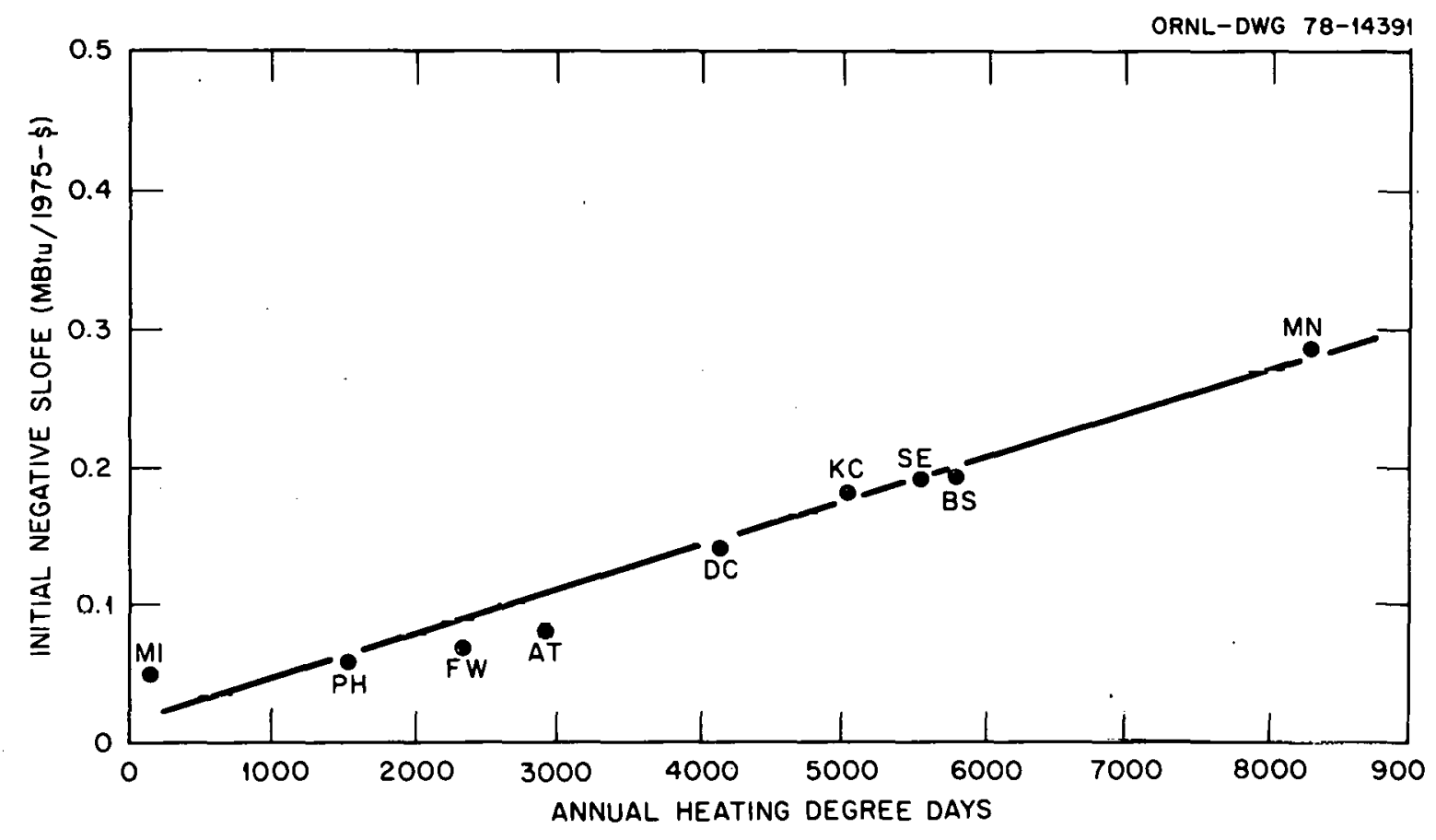

Fig. 6. Regional variation in heating load versus cost curve parameter - slope $(\mathrm{K})$. 


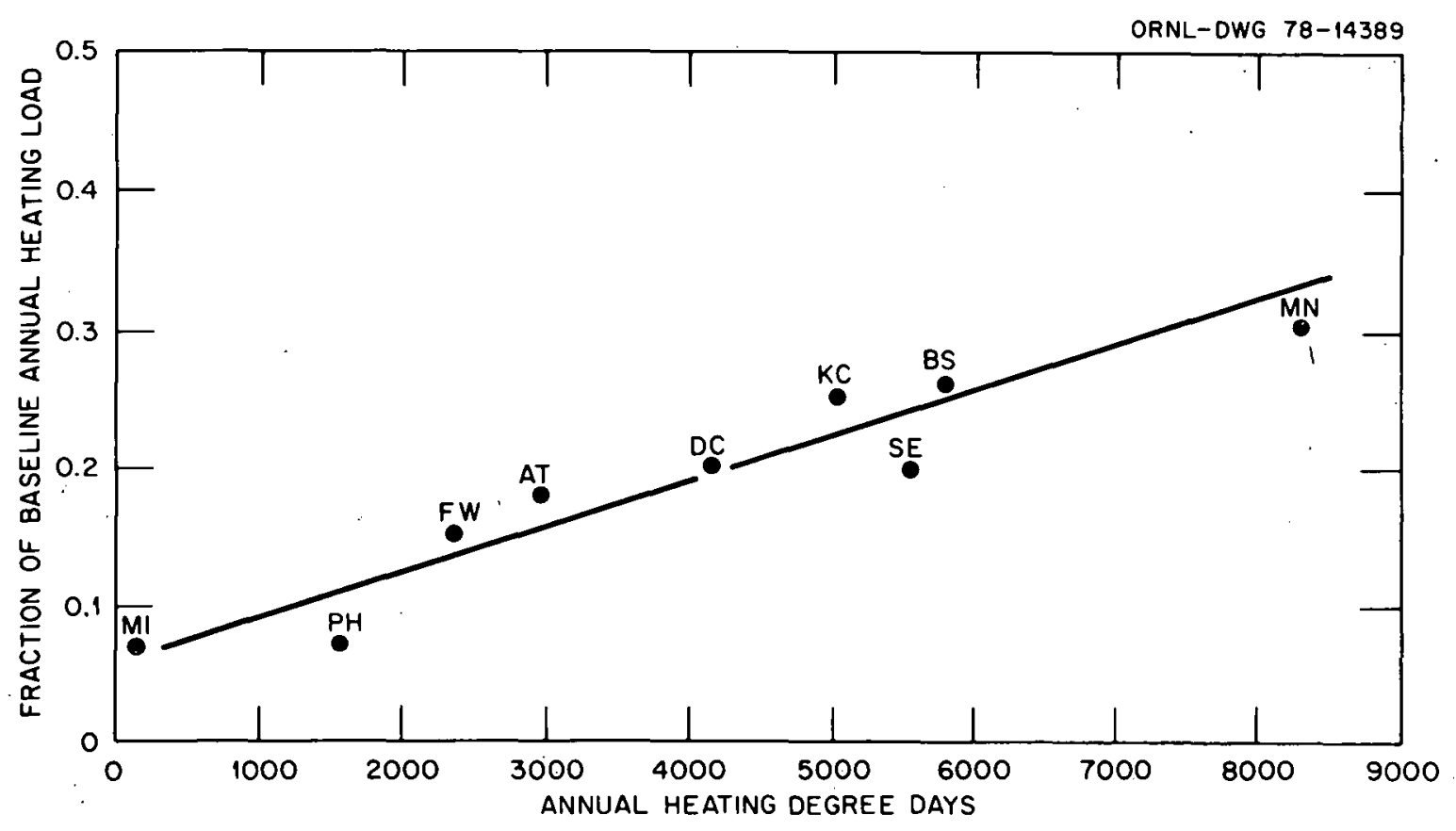

Fig. 7. Regional variation in heating load versus cost curve parameter - asymptote $\left(\mathrm{T}_{\infty}\right)$.

The asymptote, $\mathrm{T}_{\infty}$, is also an approximate linear function of heating degree days:

$$
\mathrm{T}_{\infty} \approx 3.33 \mathrm{E}-5 \cdot \mathrm{HDD}+0.055
$$

This relationship implies that larger percentage reductions in heating load are possible in mild climates than in cold climates.

The slope results are similar to those computed for mobile homes. The asymptote versus HDD relationship is slightly different. $T_{\infty}$ increases linearly up to about $3600 \mathrm{HDD}$ in the mobile home study and then remains constant for colder locations. However, variations in the two curve shapes are not large after subtracting the bias due to differences in the reference design.

The relationship between annual heating and cooling loads for Kansas City is shown in Fig. 8. Results for all locations are in Appendix Figs. A-10 through A-18. The potential for energy conservation in cooling is much less than for heating. Internal loads, which are not 


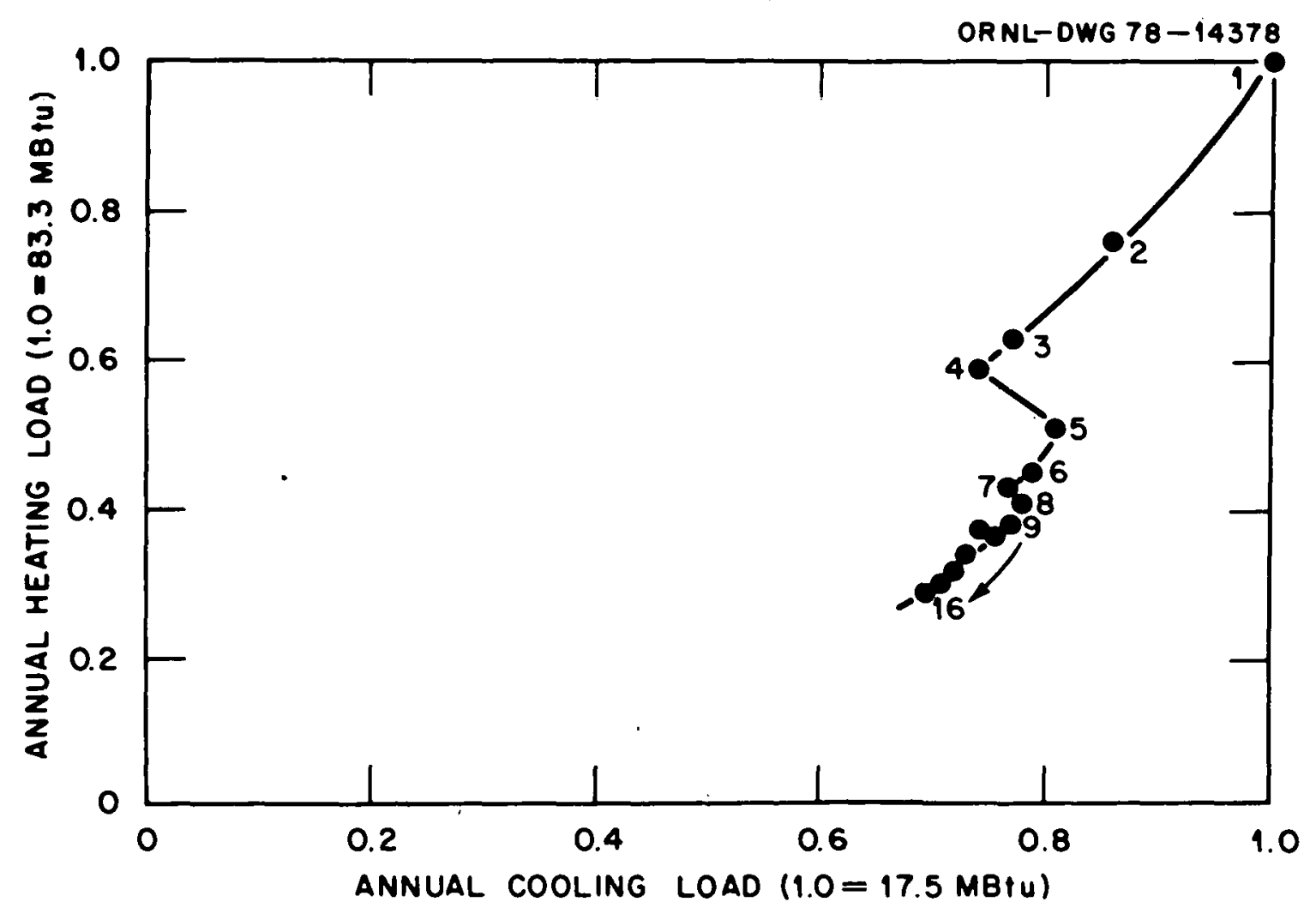

Fig. 8. Heating/cooling load relationship - Kansas City.

affected by the design options studied here, is the major reason for reduced savings. Maximum reductions range from 20 to 40 percent of the baseline. Options $\$ 5$ and $\# 8$ (additional floor insulation) increase the cooling load (see Fig. 8 and Figs. A-10 through A-18). This means that during the cooling season, the net heat flow through the floors is outward. Insulation impedes this flow, resulting in a greater cooling load.

The optimization analysis was performed for electric and natural gas heat, with and without air-conditioning, at a $5 \%$ real interest rate (using nominal values listed in Table 6). Table 8 contains results for Kansas City. Results for all nine locations are in Appendix Tables A-10 through A-18. The results include columns labeled NPW (net present worth of savings) and PB (simple payback period). The largest NPW value, the optimal solution, is underlined for each case. Negative 
Table 8. Economic analysis results - Kansas City

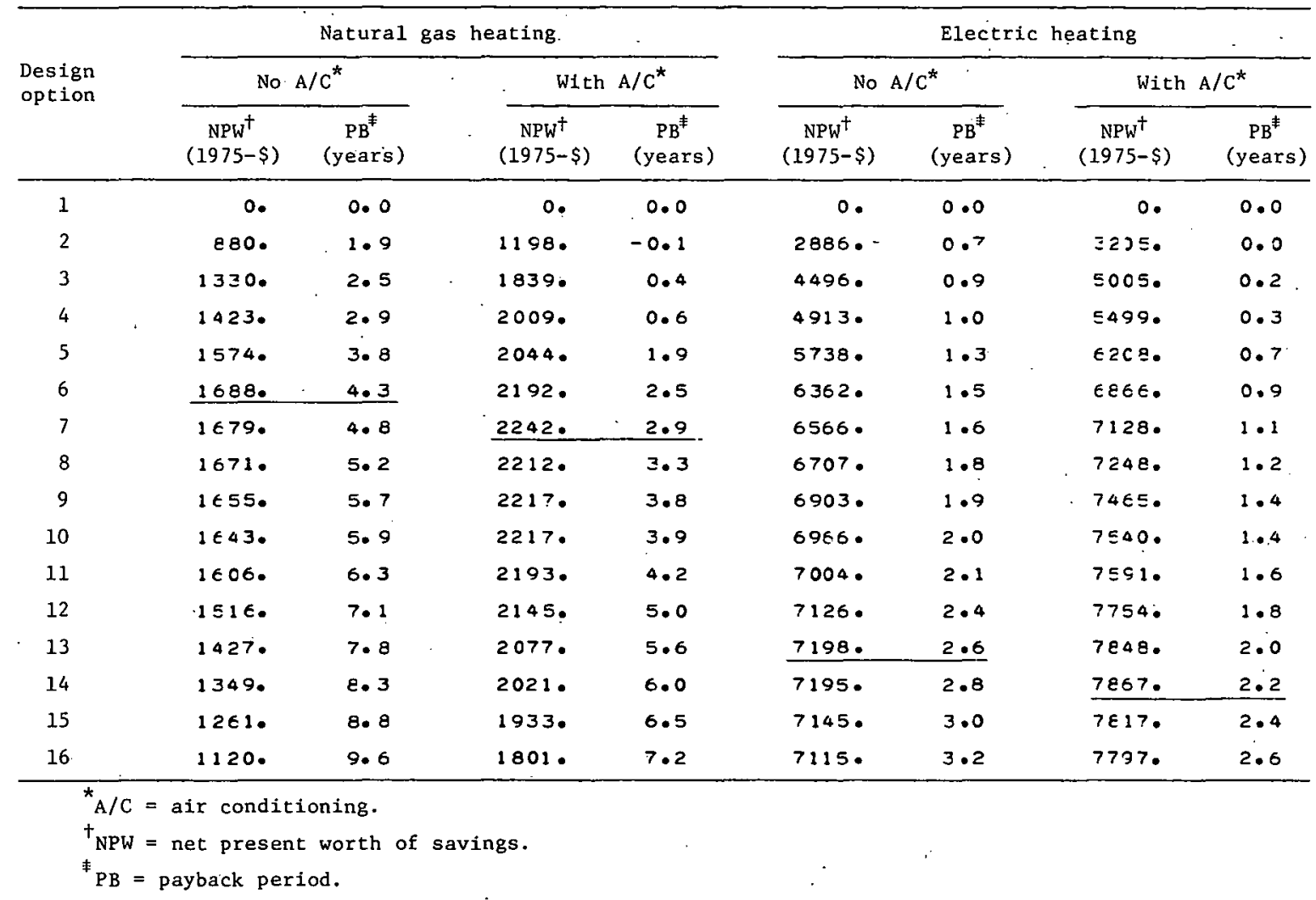

paybacks occasionally occur when savings due to size reduction in HVAC equipment exceed the additional design option cost, resulting in no net cost for the option.

Figure 9 shows the regional variation in additional cost relative to the baseline configuration for the optimal design selection. The existing thermal standard, 1974 HUD-MPS, is also shown. The results are similar to those found in the mobile home analysis. The existing HUD-MPS compares favorably to the optimum for natural gas users where the number of heating degree days is less than 3500. The large difference between the curves for electricity and natural gas demonstrates the need for a standard based on fuel price as well as climate. Breakpoints at 2500, 4500, and 8000 heating degree days on the HUD-MPS curve in Fig. 9 (and other figures to follow) are due to discontinuities in the requirements of the standard. A requirement based on. a continuous function, such as recommended in ASHRAE 90-75 21 would provide greater sensitivity to changes in climate.

Figures 10,11 , and 12 show regional variation in annual primary energy savings, additional initial investment, and annual fuel bill 


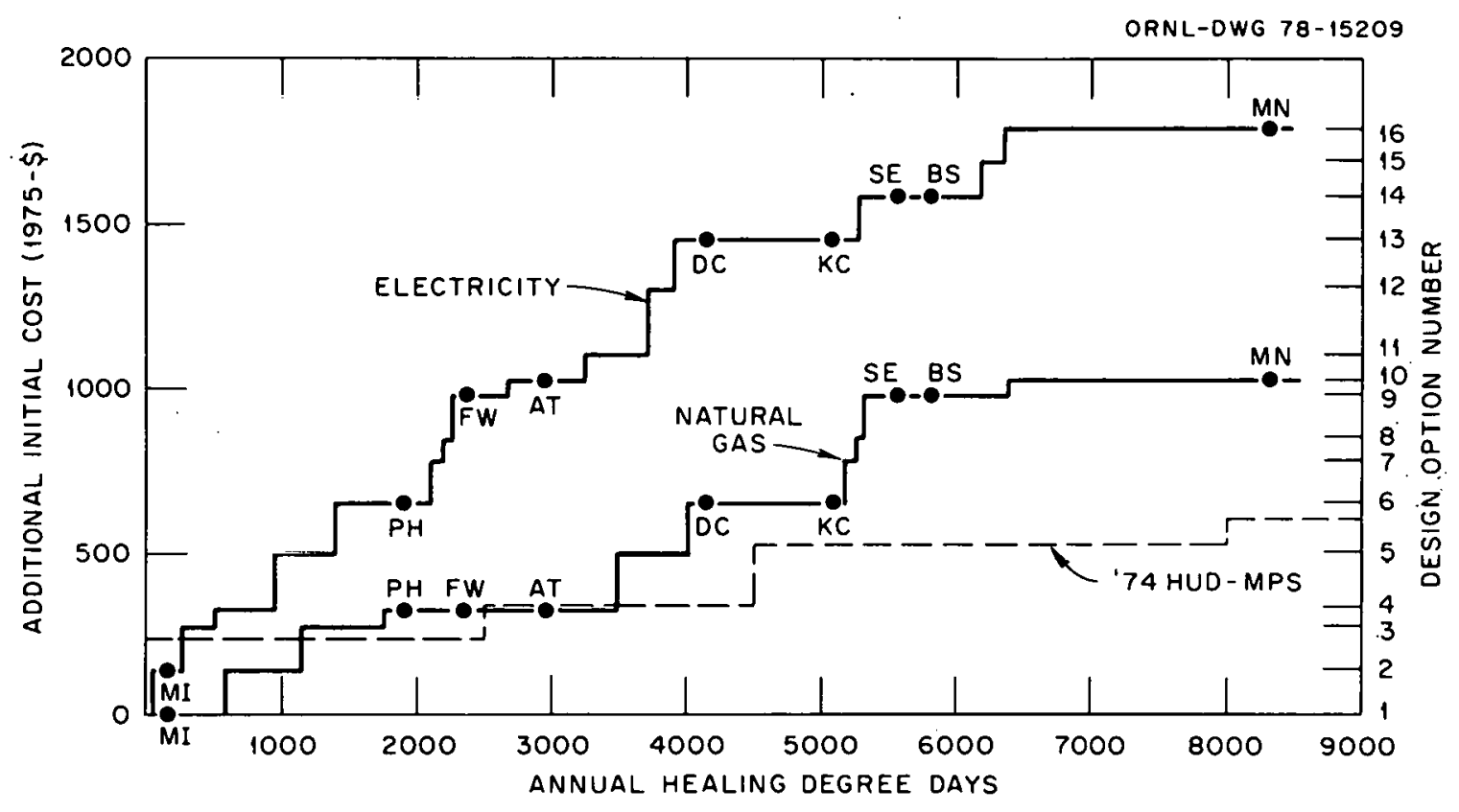

Fig. 9. Regional variation in additional cost for optimal design selection.

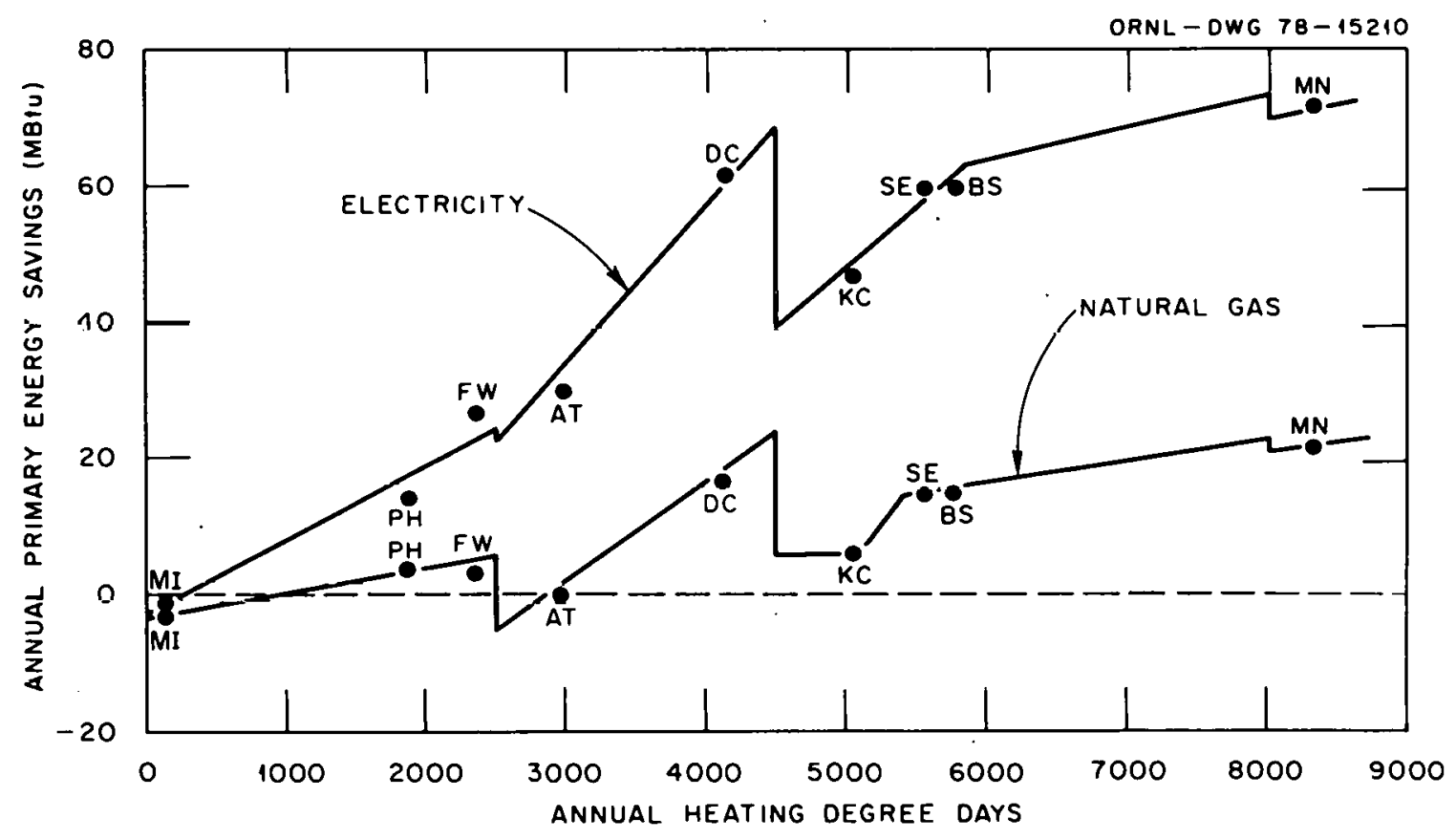
HUD-MPS.

Fig. 10, Regional variation in energy savings relative to 1974 


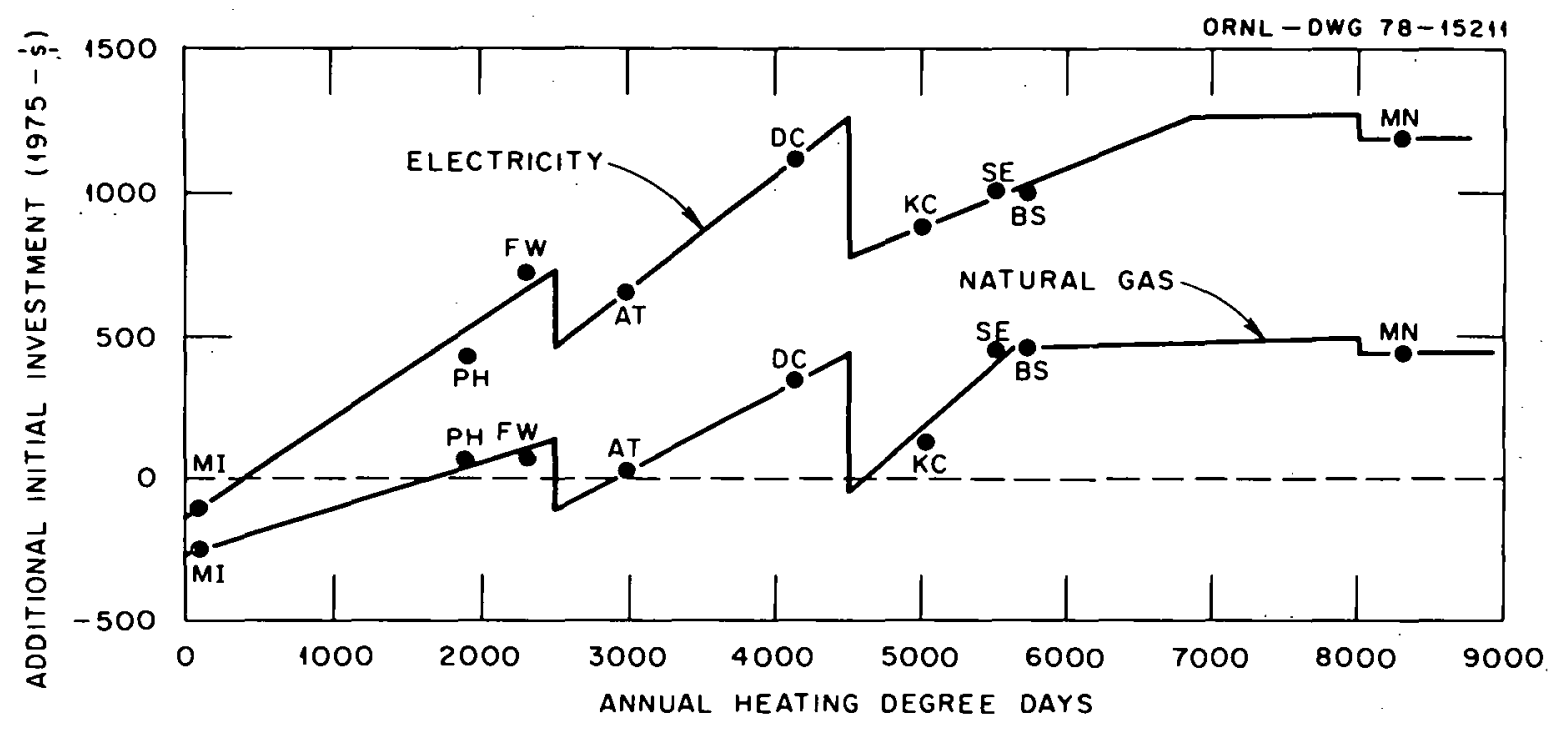

Fig. 11. Regional variation in additional investment for optimal design relative to 1974 HUD-MPS.

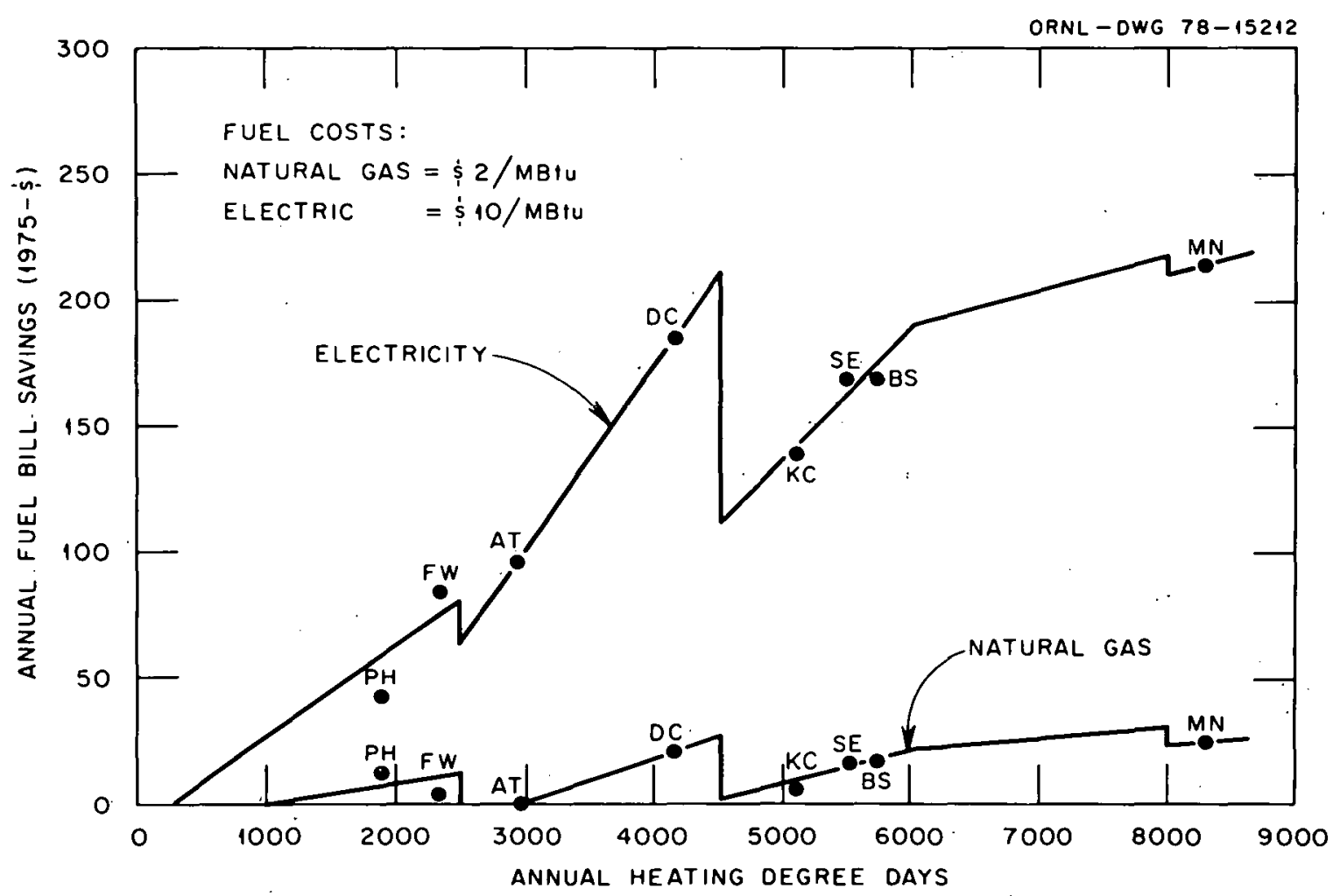

Fig. 12. Regional variation in annual fuel bill savings for optimal design relative to 1974 HUD-MPS. 
savings, respectively, relative to the 1974 HUD-MPS standards. Using Fig. 10, an estimate of energy savings is possible for the optimum design relative to the existing HUD-MPS. Approximately one million homes are purchased each year; 50 percent use electric heating; 40 percent use natural gas (Table 4) for heating. The estimated annual primary energy saving is about 25 trillion Btu. Assuming a primary energy cost of $\$ 2.50 / \mathrm{MBtu}$, this amounts to $\$ 63$ million annually or about $\$ 60$ per new homeowner.

Figures 11 and 12 show that the additional initial investment relative to HUD-MPS is 500 to $\$ 1200$ for electricity with an average of six years payback, and zero to $\$ 500$ for natural gas with paybacks around 20 years.

Sensitivity Analysis

Because of the many variables that affect these results, a strategy was developed to reduce the number of cases needed to test sensitivity of results. Keeping fuel costs and interest rates constant, two different conditions were investigated. The first uses the underlined variables in the range column of Table 6 in an optimization analysis for maximum investments. The second optimization analysis was performed with the other range column values to determine minimum investments. Results are shown in Tables 9 and 10 for natural gas and electric heating. For gas the maximum variation in additional investment ranges from zero to $\$ 800$ (zero to $\$ 400$ for deviation from the nominal). Except for gas heating in the three coldest locations, Seattle, Boston, and Minneapolis, these results are similar to those for mobile homes. Variations for electricity are much smaller. This is because the nominal optimum values for the higher-priced electriclcy are located on the "flat" part of the load/ cost curve. In this region the optimum is less sensitive to changes in parameters.

The effects of varying fuel prices and interest rates, using nominal values for other variables in Table 6, are shown in Fig. 13. Lines in the diagram define boundaries of the areas where a particular design option is optimum. Results show high sensitivity to fuel prices at current real (nominal minus inflation) interest rates, about $5 \%$ 
Table 9. Effects of changes in variable parameters on optimal design selection - natural gas heat*

\begin{tabular}{lccccc}
\hline & \multicolumn{2}{c}{ Design option } & & $\begin{array}{c}\text { Incremental } \\
\text { investment } \\
(1975-\$)\end{array}$ & $\begin{array}{c}\text { Difference in } \\
\text { energy use } \\
\text { (MBtu/yr) } \\
\text { (max.-min.) }\end{array}$ \\
\cline { 2 - 5 } Max. & Nom. & Min. & & (min.) \\
\hline Minneapolis & 13 & 10 & 6 & 800 & 28.7 \\
Boston & 10 & 9 & 6 & 400 & 11.5 \\
Seattle & 10 & 9 & 6 & 400 & 12.1 \\
Kansas City & 9 & 6 & 6 & 340 & 9.7 \\
Washington, D.C. & 6 & 6 & 4 & 300 & 15.5 \\
Atlanta & 6 & 4 & 4 & 300 & 10.7 \\
Fort Worth. & 4 & 4 & 3 & 60 & 2.4 \\
Phoenix & 4 & 4 & 3 & 60 & 3.4 \\
Miami & 1 & 1 & 1 & 0 & 0 \\
\hline
\end{tabular}

${ }^{*}$ Fuel price $=\$ 2.00 / \mathrm{MBtu} ;$ real interest rate $=5 \%$.

Table 10. Effects of changes in variable parameters on optimal design selection - electric heat*

\begin{tabular}{|c|c|c|c|c|c|}
\hline & \multicolumn{3}{|c|}{ Design option } & \multirow{2}{*}{$\begin{array}{l}\text { Incremental } \\
\text { investment } \\
\text { (1975-\$) } \\
\text { (max.-min.) }\end{array}$} & \multirow{2}{*}{$\begin{array}{l}\text { Difference in } \\
\text { energy use } \\
\text { (MBtu/yr) } \\
\text { (max.-min.) }\end{array}$} \\
\hline & Max. & Nom. & Min. & & \\
\hline Minneapolis & 16 & 16 & 16 & 0 & 0 \\
\hline Boston & 14 & 14 & 14 & 0 & 0 \\
\hline Seattle & 14 & 14 & 13 & 150 & 1.8 \\
\hline Kansas City & 14 & 13 & 13 & 150 & 1.2 \\
\hline Washington, D.C. & 13 & 13 & 13 & 0 . & 0 \\
\hline At lanta & 11 & 10 & 10 & 80 & 0.5 \\
\hline Fort Worth & 10 & 10 & 7 & 240 & 1.8 \\
\hline Phoenix & 7 & 6 & 4 & 450 & 3.5 \\
\hline Miami & 2 & 2 & 2 & 0 & 0 \\
\hline
\end{tabular}

${ }^{*}$ Fuel price $=\$ 10 / \mathrm{MBtu} ;$ real interest rate $=5 \%$. 
annually. On the other hand, the results are rather insensitive to the range of interest rates considered.

To evaluate the effects of rising fuel prices (relative to inflation) with Fig. 13, a uniform series (uniform series capital recovery factor, USCR) equivalent of an escalating fuel price was computed. ${ }^{l}$ The coefficients used to modify the constant-valued energy price by multiplication are in Table 11.

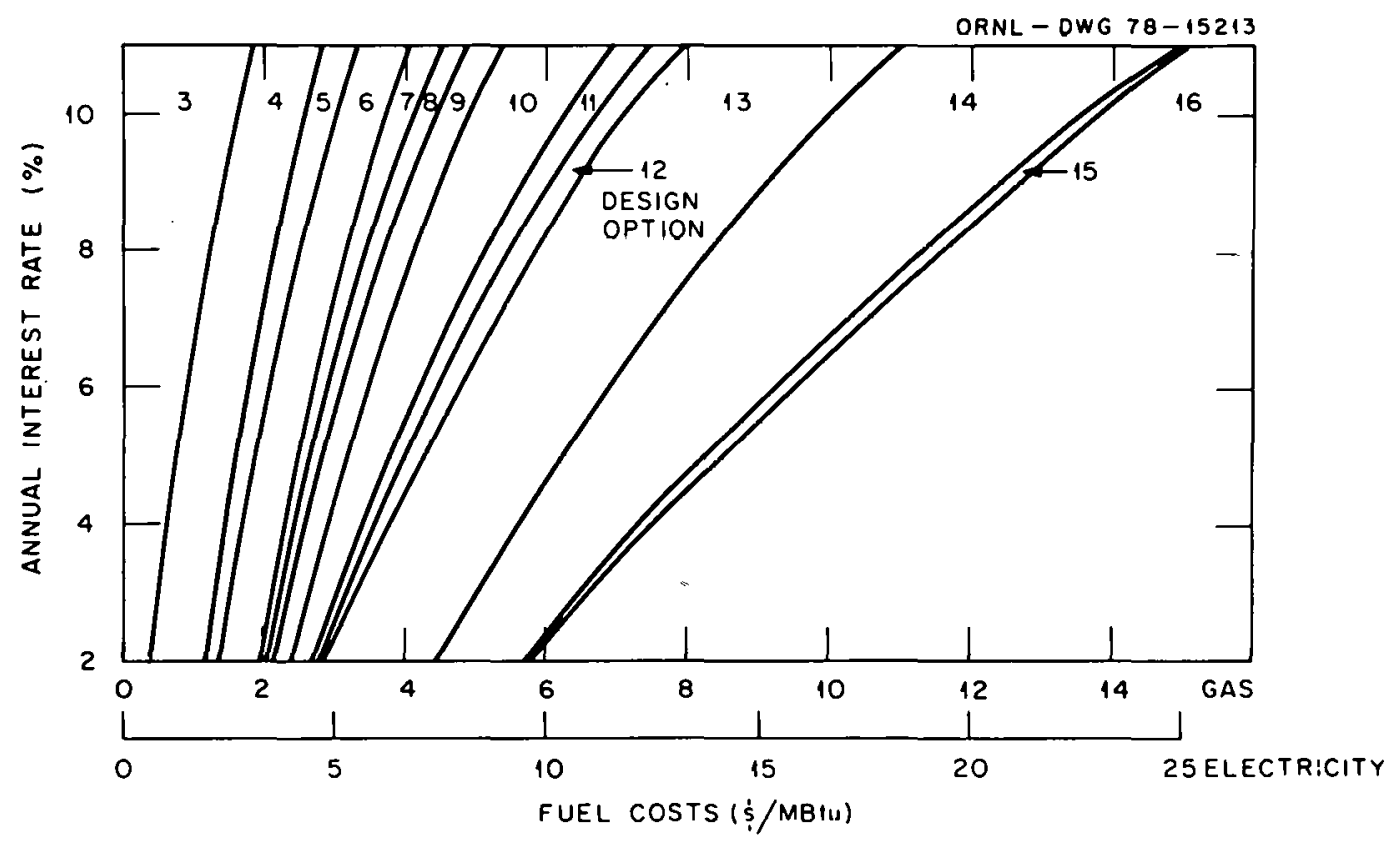

Fig. 13. Optimal design selection sensitivity to changes in fuel cost and interest rates - Kansas City.

Table 11. Fuel price escalation factors (USCR)

\begin{tabular}{|c|c|c|c|}
\hline \multirow{2}{*}{$\begin{array}{l}\text { Real fuel price } \\
\text { escalation rate } \\
(\%)\end{array}$} & \multirow[b]{2}{*}{ USCR } & \multicolumn{2}{|c|}{$\begin{array}{c}\text { Constant-valued annual fuel cost } \\
\text { for present fuel cost } \\
\text { equivalent to: }\end{array}$} \\
\hline & & $\$ 2 / M B L u$ & $\$ 10 /$ MBtu \\
\hline 1 & 1.06 & 2.12 & 10.60 \\
\hline 2 & 1.12 & 2.24 & 11.20 \\
\hline 3 & 1.19 & 2.38 & 11.90 \\
\hline 4 & 1.27 & 2.54 & 12.70 \\
\hline 5 & 1.35 & 2.70 & 13.50 \\
\hline
\end{tabular}


6. SUMMARY AND CONCLUSIONS

This report presents results of detailed thermal analyses of new single-family dwellings in nine U.S. cities. Results include annual heating load versus additional initial cost relationships and optimization analysis for each location (contained in the Appendix). The annual loads calculation and cost surveys were based on a report by Petersen at the National Bureau of Standards which used the NBSLD computer code. The economic analyses were conducted with an updated version of a computer program written at ORNL.

The purpose of this report is to evaluate the cost-effectiveness of various energy-conserving design options. An optimal design (i.e., one that minimizes lifecycle cost of purchase and operation) is defined for each location (see Figs. 10-12). Design options studied include additional wall, attic, and floor insulation, multiple-paned windows and sliding glass doors, storm doors, 6" exterior walls, and styrofoam wall sheathing.

Figure 4 shows that annual heating and cooling loads vary linearly with number of heating and cooling degree days, respectively. Petersen ${ }^{7}$ showed that this holds trup for homoc of varying leylees of thermal protection by adjusting the degree day reference temperature.

The most cost-effective order of implementation was generally constant for all locations for heating only (Tables A-1 through A-9 and Figures A-1 through A-9 in the Appendix). However, the cost-effectiveness of floor insulation did decrease relative to the other options for milder climates. Regional variation in basic heating load versus initial cost relationships is shown in Figs. 6 and 7 .

Results of the optimization analysis for heating only are compared to the existing single-family thermal standard, 1974 HUD-MPS, in Figs. 9-12. For natural gas-heated homes the comparison is favorable for much of the nation, with major differences only in areas above 5200 heating degree days. All areas above 1000 heating degree days for electric heating show large differences. Paybacks for natural gas range from 15 to 25 years and for electricity, four to six years. These 
results indicate that the HUD-MPS would be more effective if they were sensitive to fucl prices as well as to climate.

The National Association of Home Builders offers a good example of flexible thermal performance guidelines, INAHB Thermal Performance GuideZines for one and Two Family Dwellings. 22 The document recommends various levels of insulation, storm windows, and storm doors based on climate and fuel price. An economic analysis is performed to require a specified payback period at a chosen interest rate and investment lifetime. Neither the present HUD-MPS nor the ASHRAE Standard 90-75 is sensitive to fuel prices.

A sensitivity analysis is also performed to evaluate the effects of changes in various economic parameters (with constant fuel price and interest rate) on the optimization and analysis. Results, listed in Tables 9 and 10, show that except for areas above 5500 heating degree days, even extreme cases (i.e., using extreme values which encourage or discourage investment) yield moderate results. Sensitivity to changes in fuel prices and interest rates was also examined; see Fig. 13.

In conclusion, results of the single-family dwelling analysis were similar to those found in the mobile home analysis. The format and method of analysis was established in the mobile home study and followed here. Results contained here should prove helpful in the evaluation of cost-effective thermal standards and their impact on the single-family home buyer.

\section{ACKNOWLEDGMENTS}

We appreciate the excellent cooperation and assistance from Stephen Petersen of the National Bureau of Standards. Petersen's provision of his NBSLD results was invaluable for the timely completion of this work. We also thank Jan Beyea, Roger Carlsmith, John Moyers, and Stephen Petersen for their careful reviews of this report in draft form. 


\section{THIS PAGE \\ WAS INTENTIONALLY \\ LEFT BLANK}




\section{REFERENCES}

1. Hutchins, P., and E. Hirst, Engineering-Economic Analysis of Mobile Home Thermal Performance, ORNL/CON-28, Oak Ridge National Laboratory, October 1978.

2. Hirst, E., and J. Carney, The ORNL Engineering-Economic Model of Residential Energy Use, ORNL/CON-24, Oak Ridge National Laboratory, July 1978.

3. 94th Congress, Energy Conservation and Production Act, PL 94-385, August 14, 1976.

4. Dole, S. H., Energy Use and Conservation in the Residential Sector: A Regional Analysis, R-1641-NSF, Rand Corporation, June 1975.

5. 1970 Census of Housing, Detailed Housing Characteristics, HC(1)-B1, U.S. Department of Commerce, Bureau of the Census, July 1972; also Annual Housing Survey: 1975, General Housing Characteristics, Series H-150-75A, U.S. Department of Commerce and U.S. Department of Housing and Urban Development, April 1977, also earlier, issues.

6. Kusuda, T., NBLSD, the Computer Program for Heating and Cooling Loads in Buildings, NBS-BSS-69, U.S. Department of Commerce, National Bureau of Standards, July 1976.

7. Petersen, S.R., Economics and Energy Conservation of New SingleFomily Housing, U.S. Department of Commerce, National Bureau of Standards, forthcoming.

8. Hastings, S. R., Three Proposed Typical House Designs for Energy Conservation Research, NBSIR 77-1309, U.S. Department of Commerce, National Bureau of Standards, October 1977.

9. Minimum Property Standards for One and Two Fomily Dwellings, U.S. Department of Housing and Urban Development, 1974.

10. Selected Cost Data on Residential Construction, CR-1121, NAHB Research Foundation, Inc., December 1977.

11. Thermal Characteristics of Single Fomily Detached, Single Fomily Attached, Low-Rise Multifomily, Mobile Homes, NAHB Research Foundation, Inc., October 1977.

12. Tape Reference Manual, "Test Reference Year," U.S. Department of Commerce, National Oceanographic and Atmospheric Administration, September 1976. 
13. NBSLD-XO: Expanded Output for Thermal Performance Analysis of Building Envelopes, U.S. Department of Commerce, National Bureau of Standards, forthcoming.

14. 1975 Dodge Manual for Building Construction Pricing and Scheduling, McGraw-Hil1 Information Systems Company, New York, N.Y., 1975.

15. Tax Burdens in Washington, D.C. Compared with Major State and Local Tax Burdens in the Nation's Thirty Largest Cities, 1974, Government of the District of Columbia, Department of Finance and Revenue.

16. Hise, E. C., Seasonal Fuel Utilization Efficiency of Residential Heating Systems, ORNL/NSF-EP-91, Oak Ridge National Laboratory, April 1975.

17. Heat Pump Technology, HCP/M2121-01, Gordian Associates, June 1978.

18. Residential Energy Consumption, Detailed Geographical Analysis, HIT-650-11, Hittman Associates, Inc., May 1977.

19. Moyers, J. C., The Value of Thermal Insulation in Residential Construction: Economics and the Conservation of Energy, ORNL/NSF-EP-9, Oak Ridge Nationa1 Laboratory, December 1971.

20. Delene, J. G. and J. B. Gaston, A Regional Comparison of Savings from Various Residential Energy Consemation Strategies, ORNL/TM-5146, Oak Ridge National Laboratory, February 1976.

21. ASHRAE Standard 90-75, Energy Consemation in New Building Design, The American Society of Heating, Refrigerating and Air-Conditioning Engineers, Inc:, 1975:

22. NAHB Thermal Performance Guidelines for one and Two Family Dwellings, National Association of Home Builders, 1977. 
APPENDIX

Analysis Results for all Locations 


\section{THIS PAGE}

\section{WAS INTENTIONALLY LEFT BLANK}




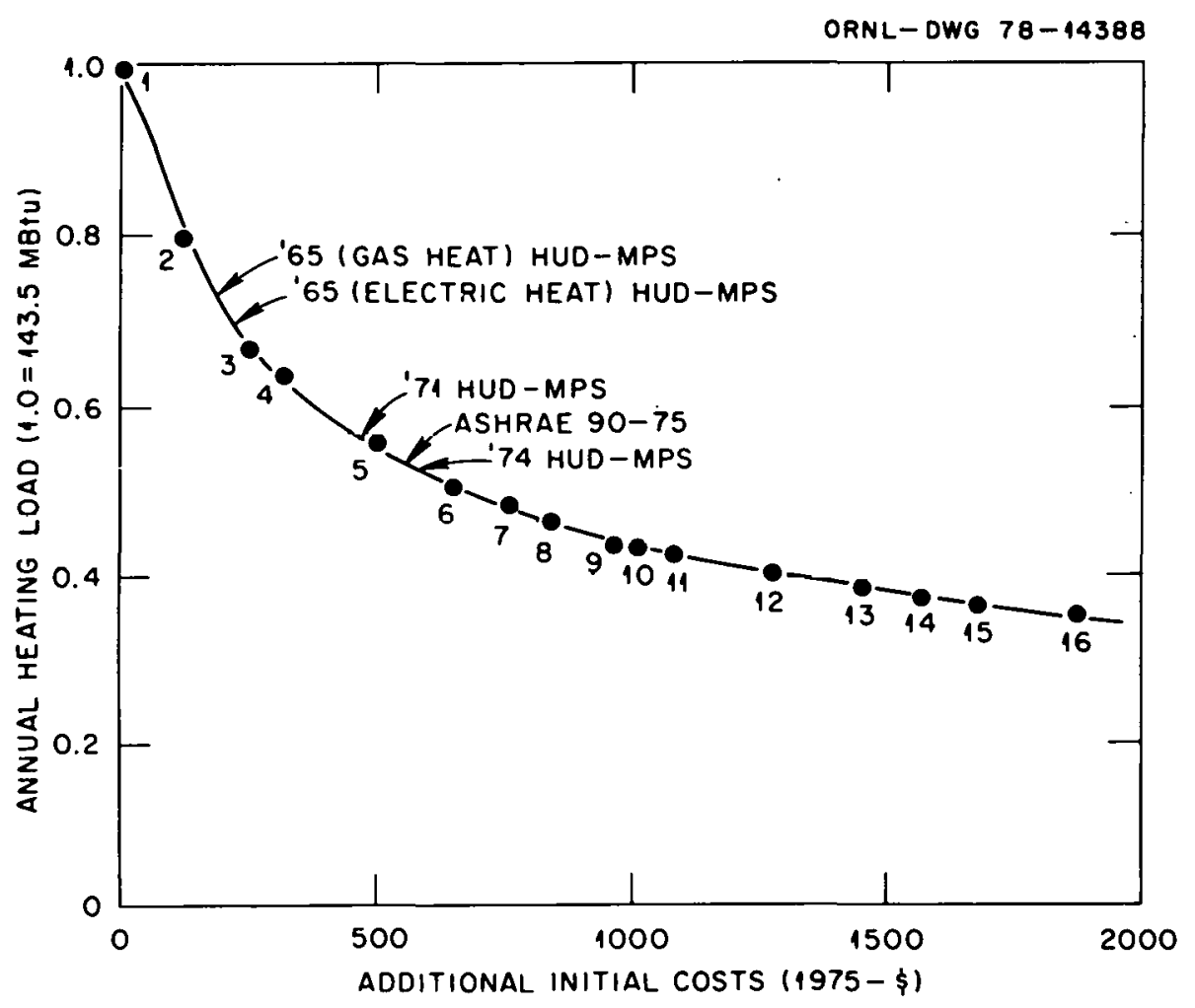

Fig. A-1. Heating Load/Cost Relationship - Minneapolis.

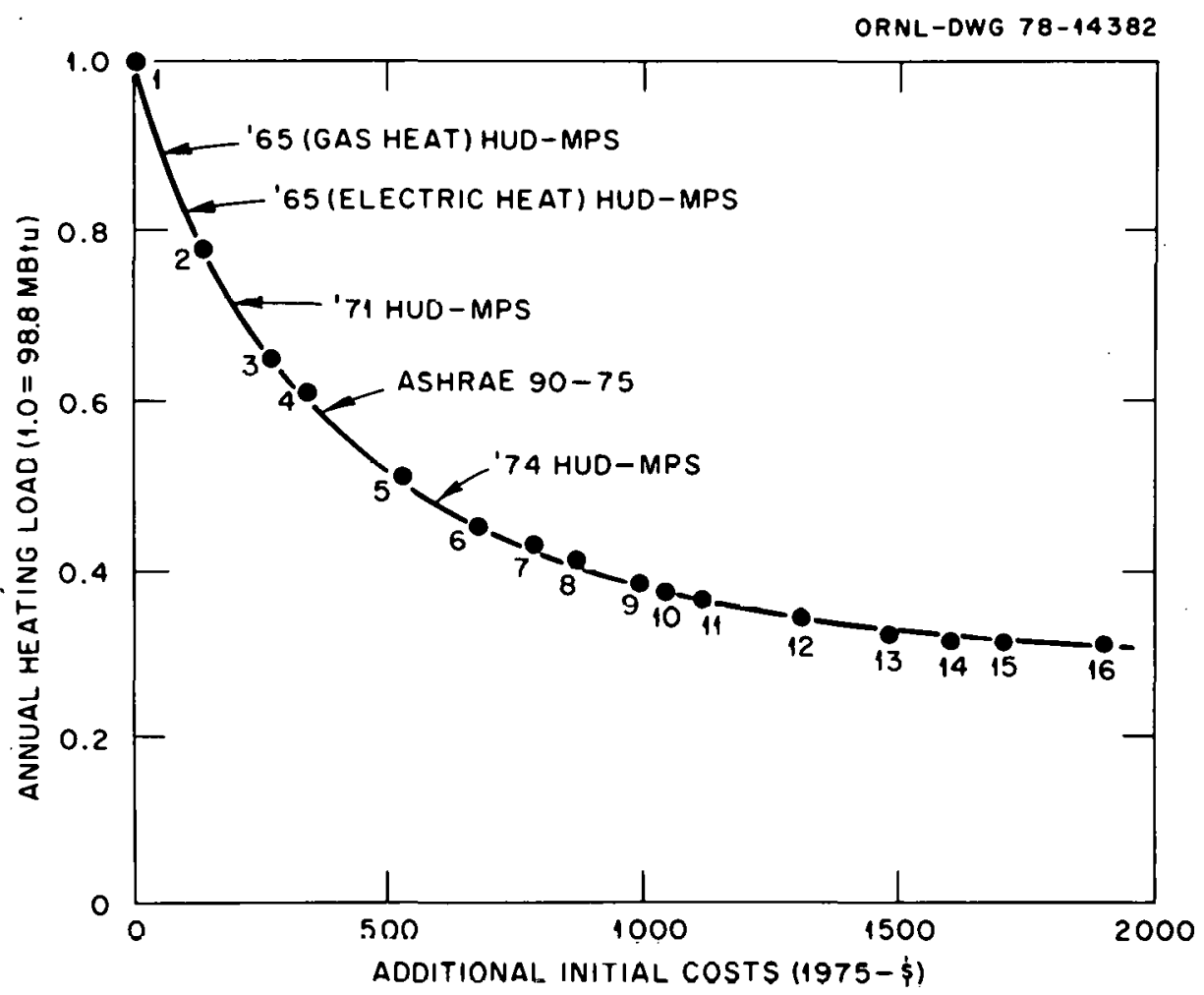

Fig. A-2. Heating Load/Cost Relationship - Boston. 


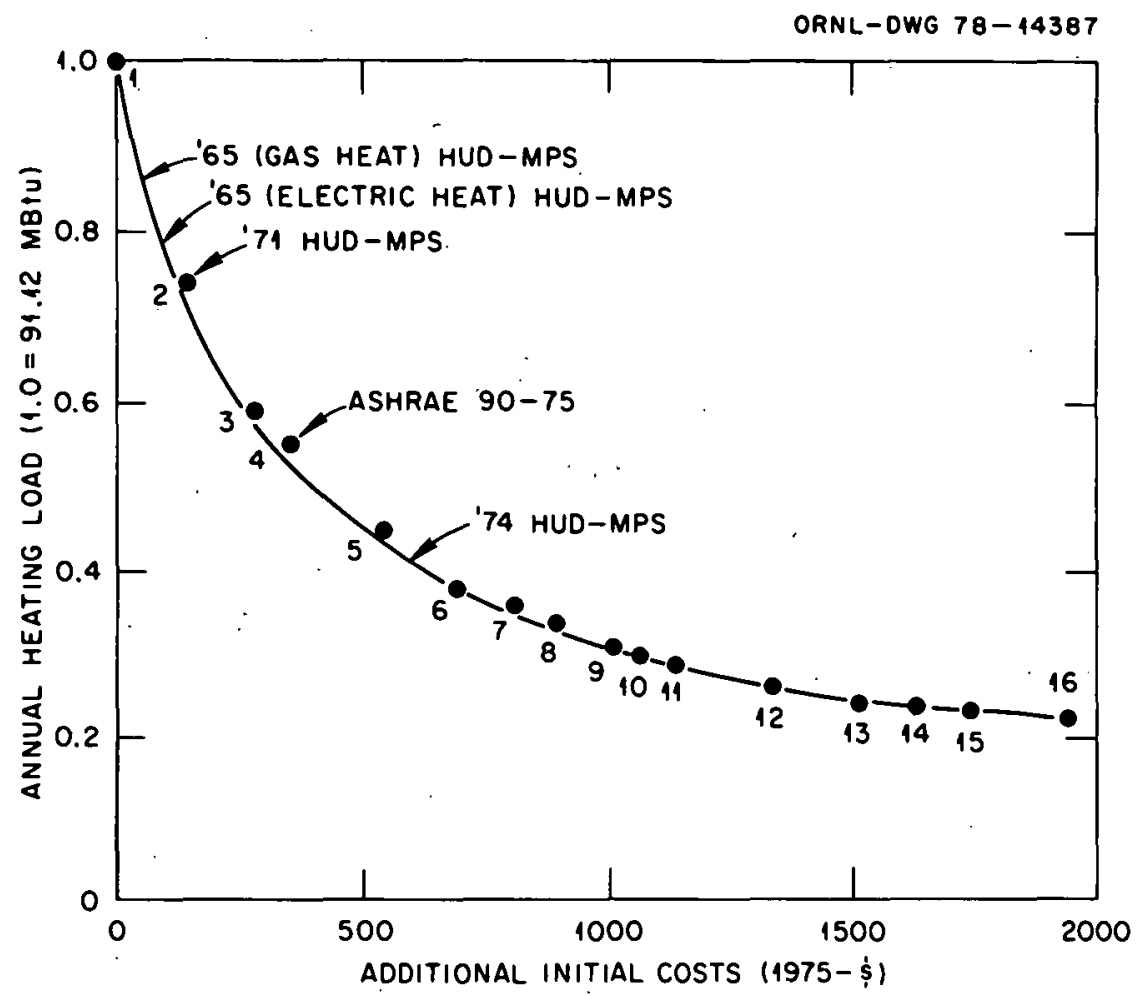

Fig. A-3. Heating Load/Cost Relationship - Seattle.

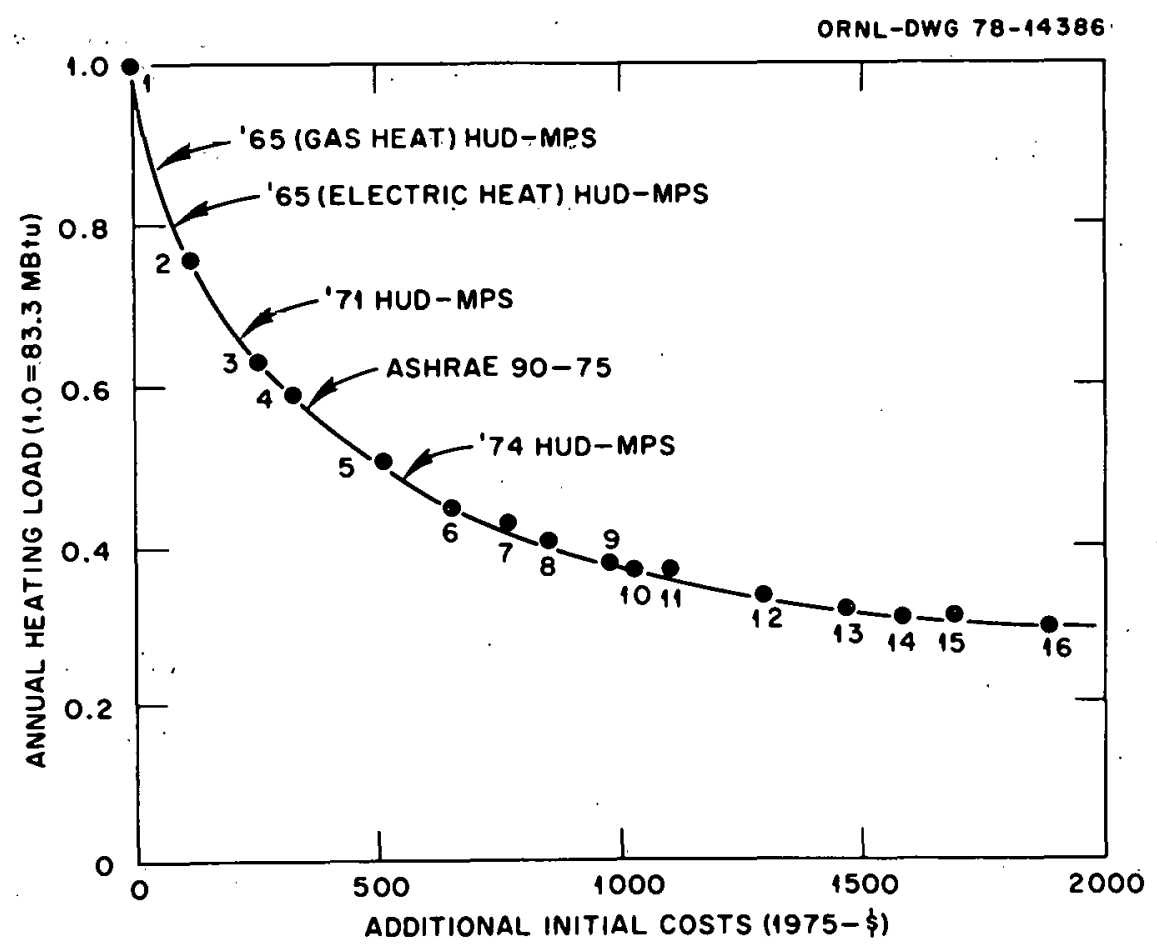

Fig. A-4. Heating Load/Cost Relationship - Kansas City. 


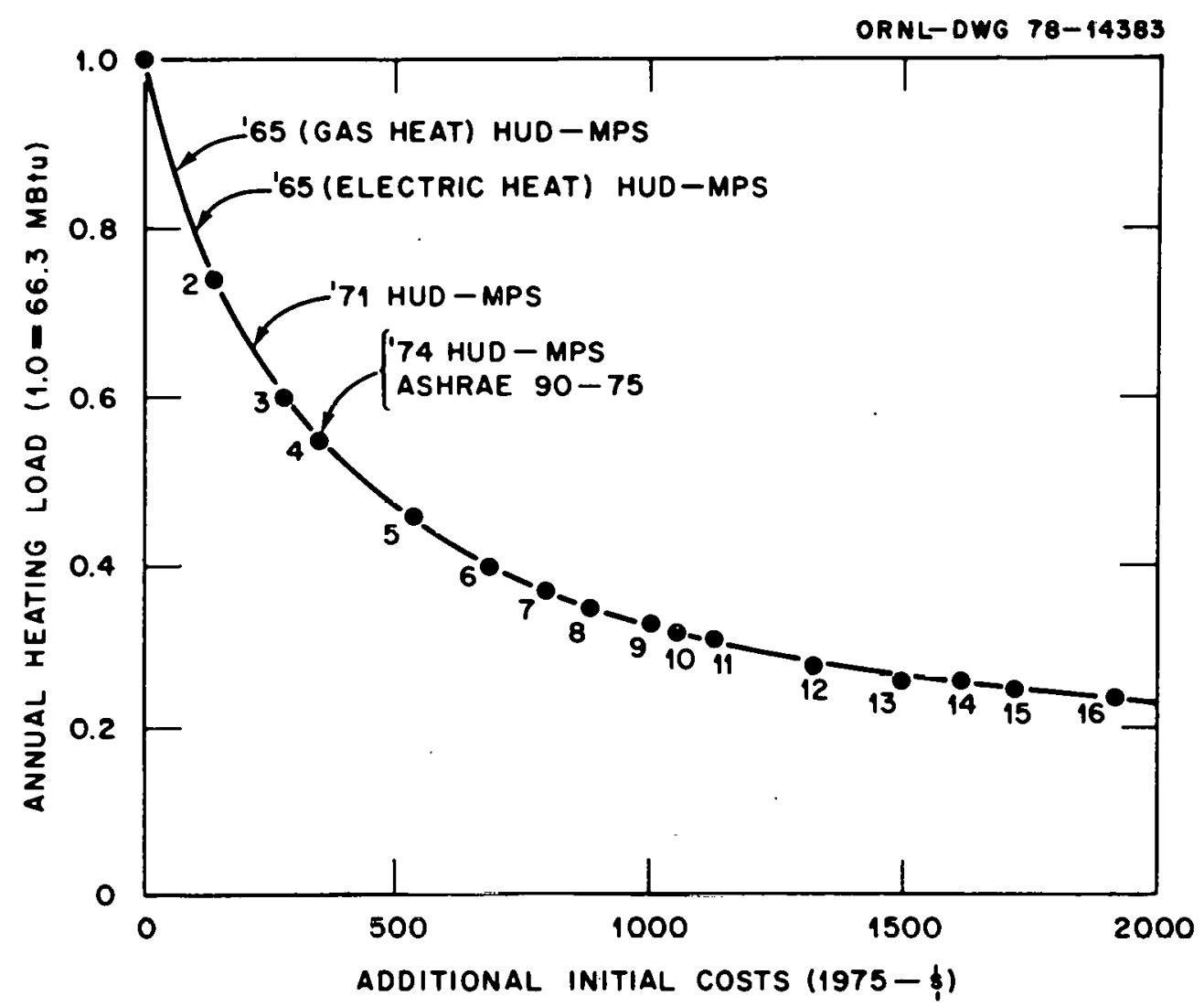

Fig. A-5. Heating Load/Cost Relationship - Washington, D.C.

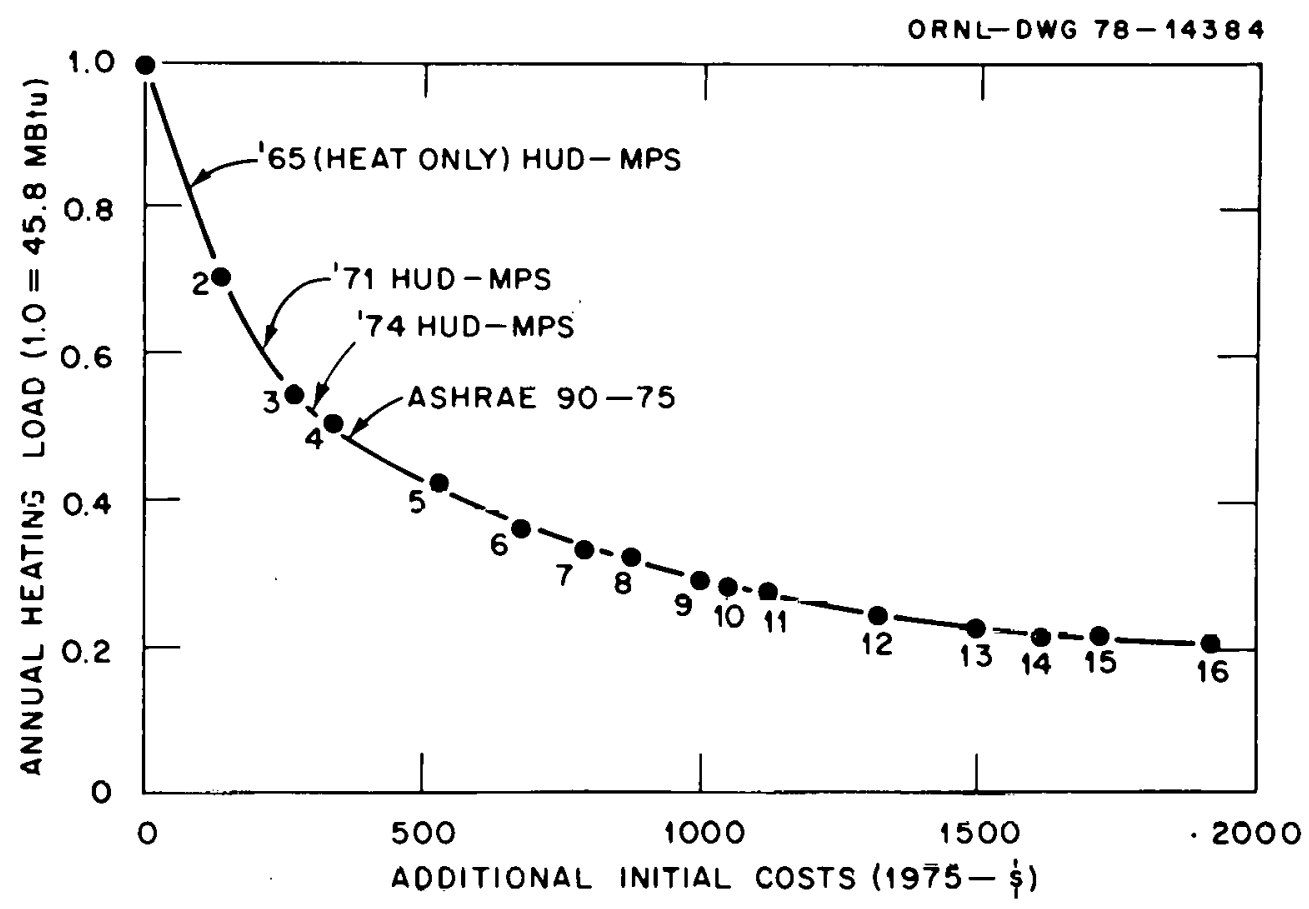

Fig. A-6. Heating Load/Cost Relationship - Atlanta. 


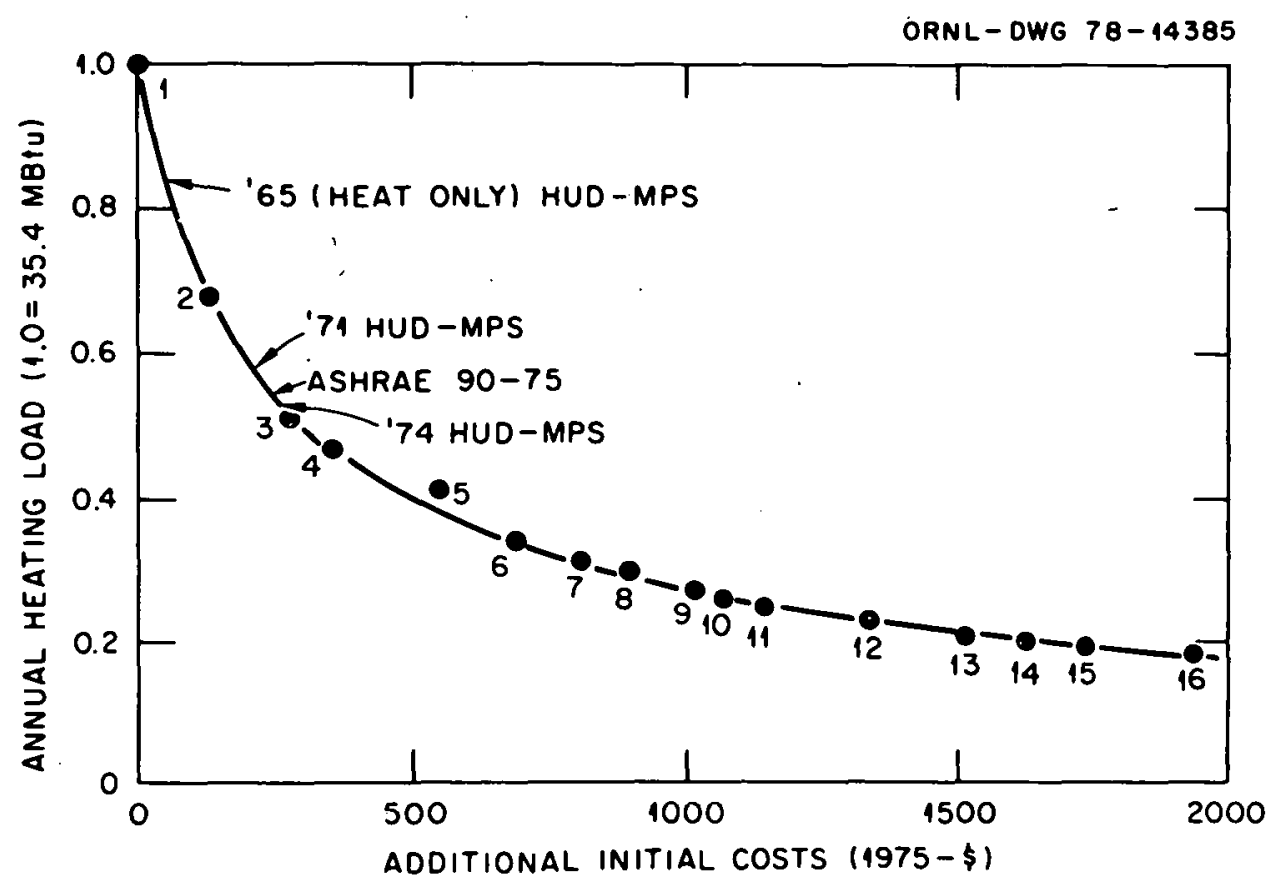

Fig. A-7. Heating Load/Cost Relationship - Fort Worth.

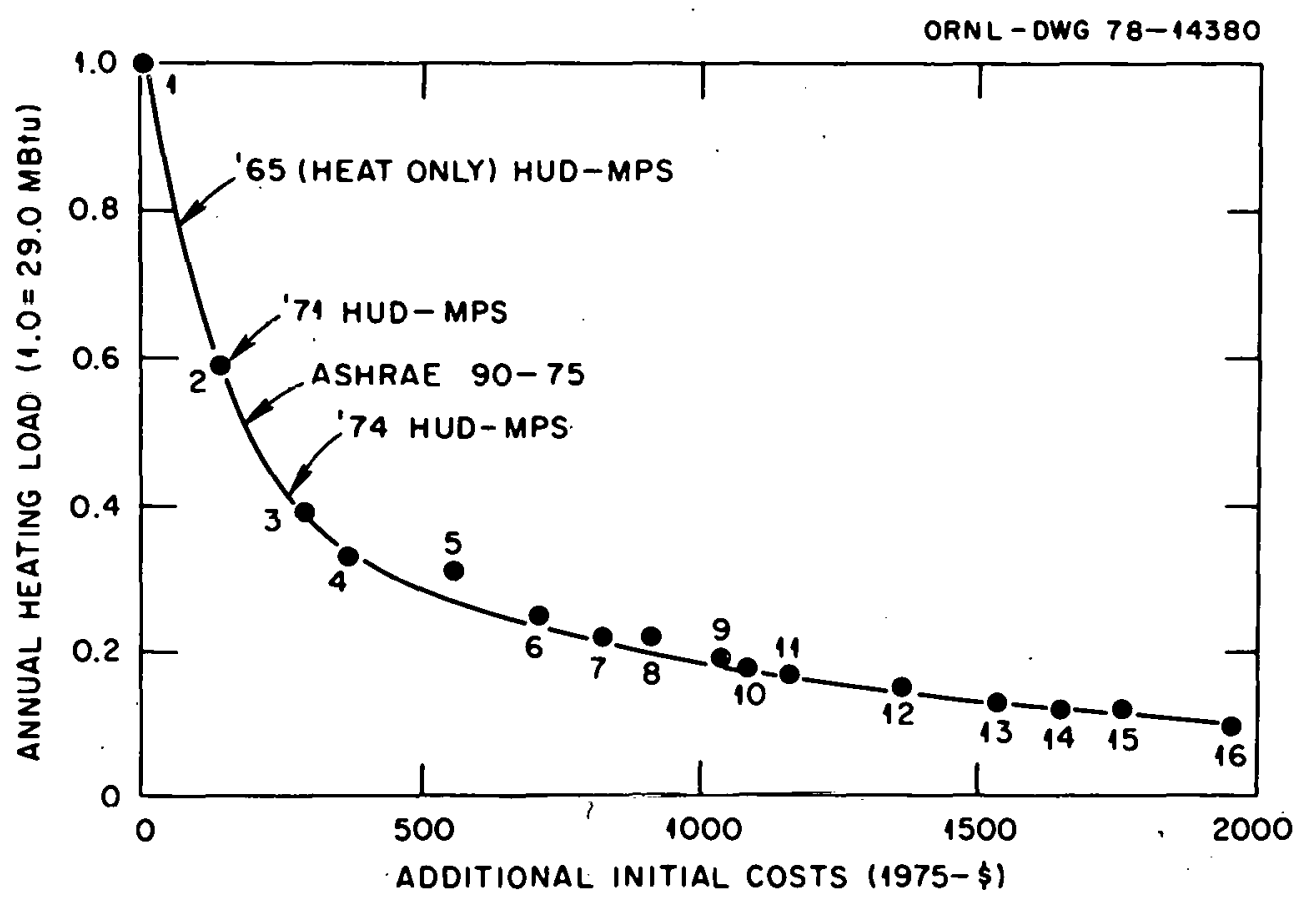

Fig. A-8. Heating Load/Cost Relationship - Phoenix. 


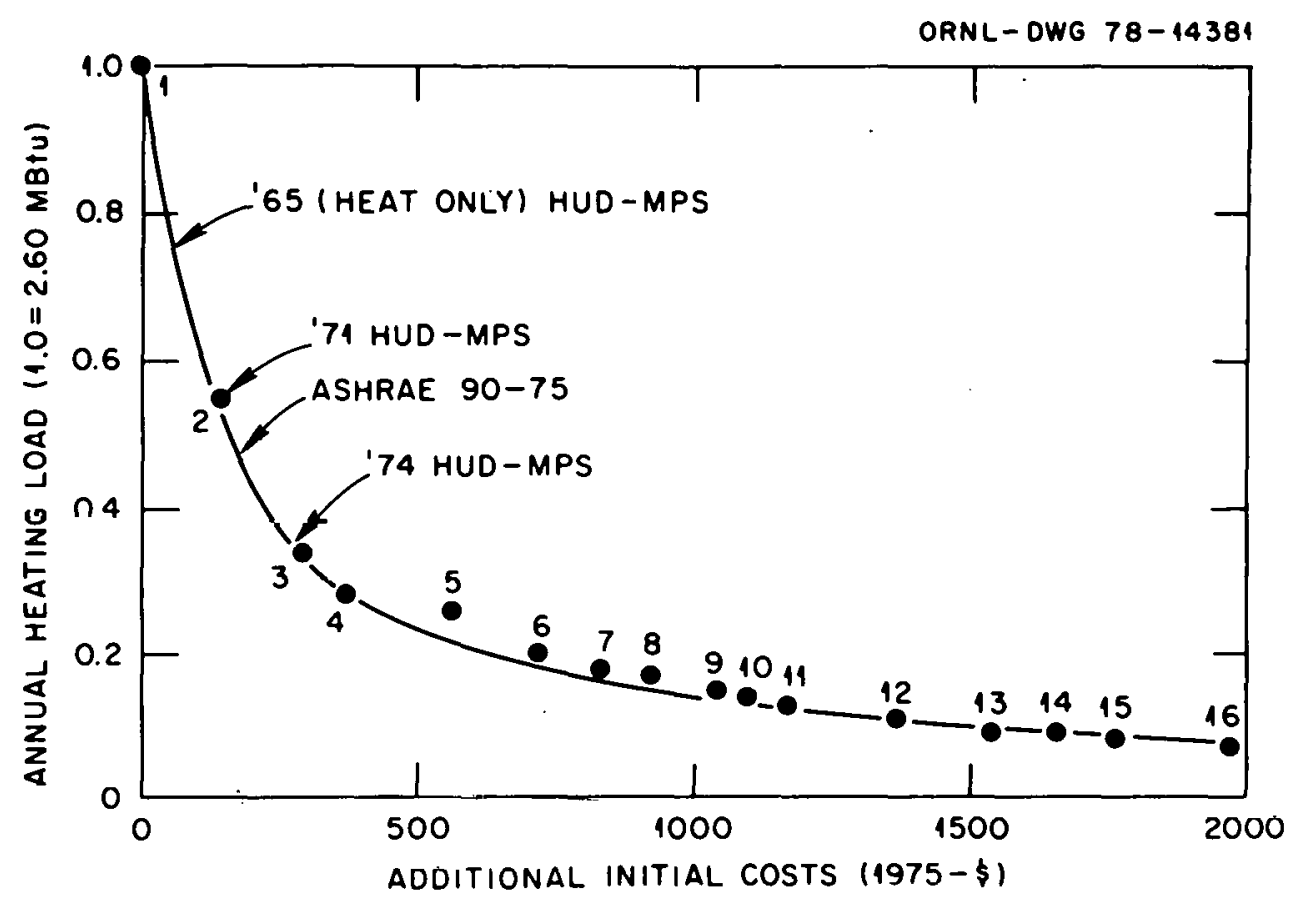

Fig. A-9. Heating Load/Cost Relationship - Miami.

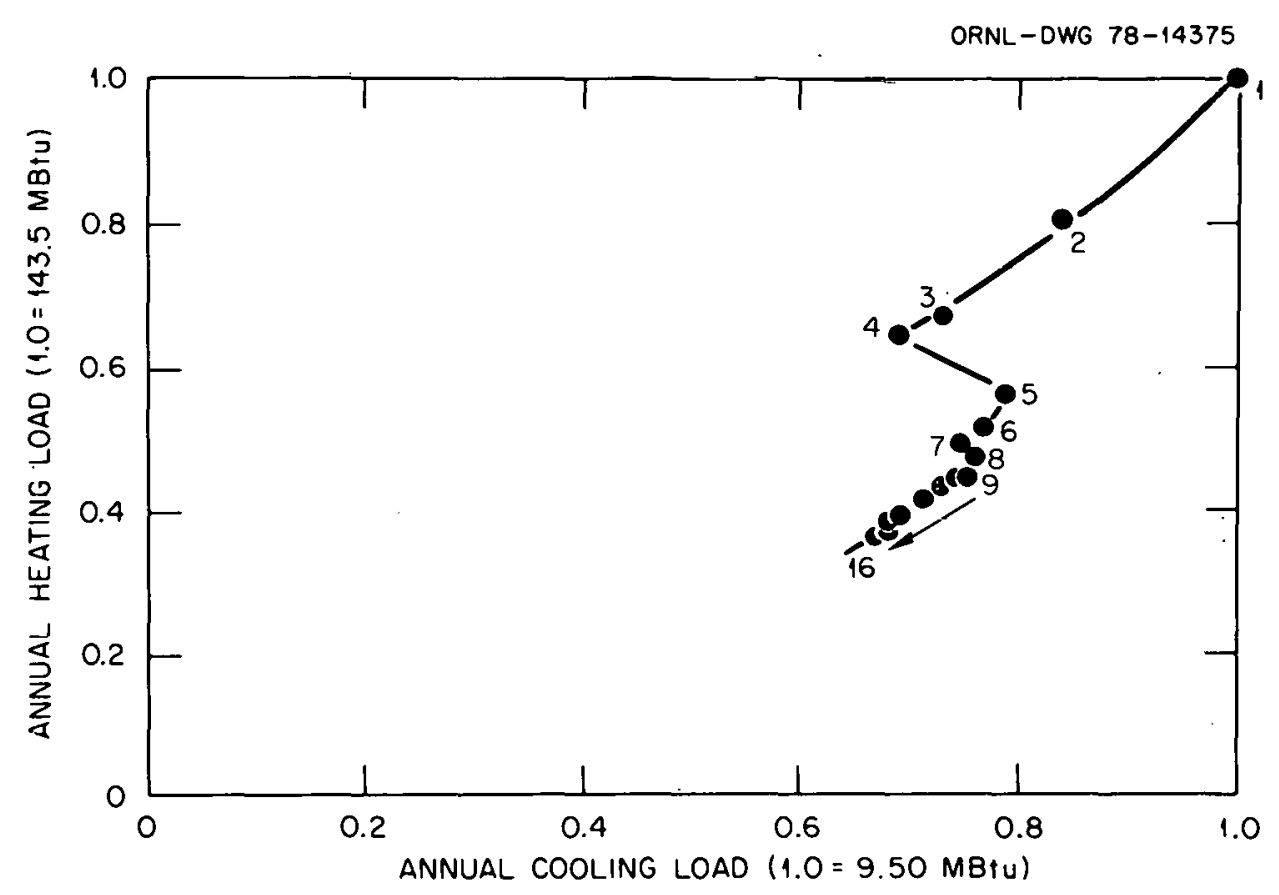

Fig. A-10. Heating/Cooling Load Relationship - Minneapolis. 


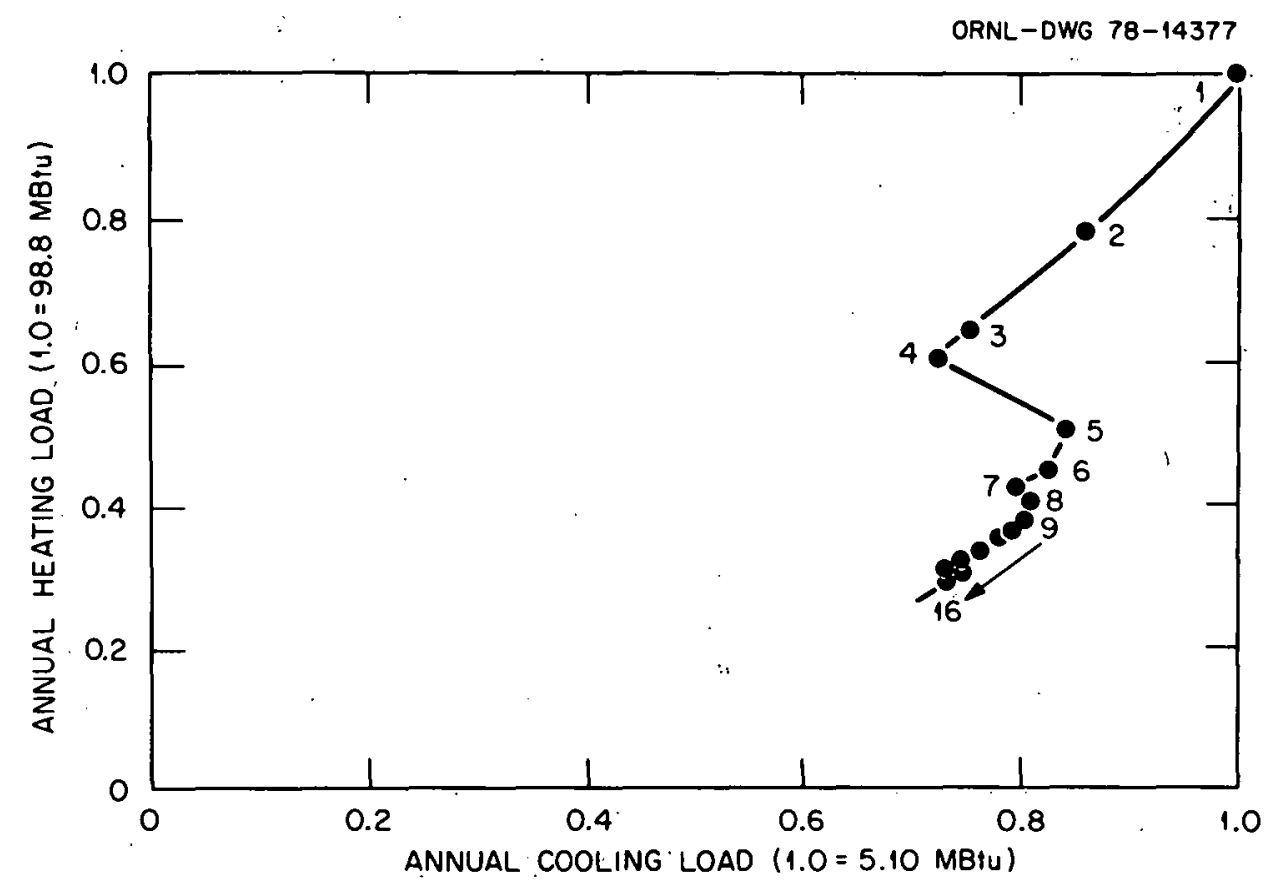

Fig. A-11. Heating/Cooling Load Relationship - Boston.

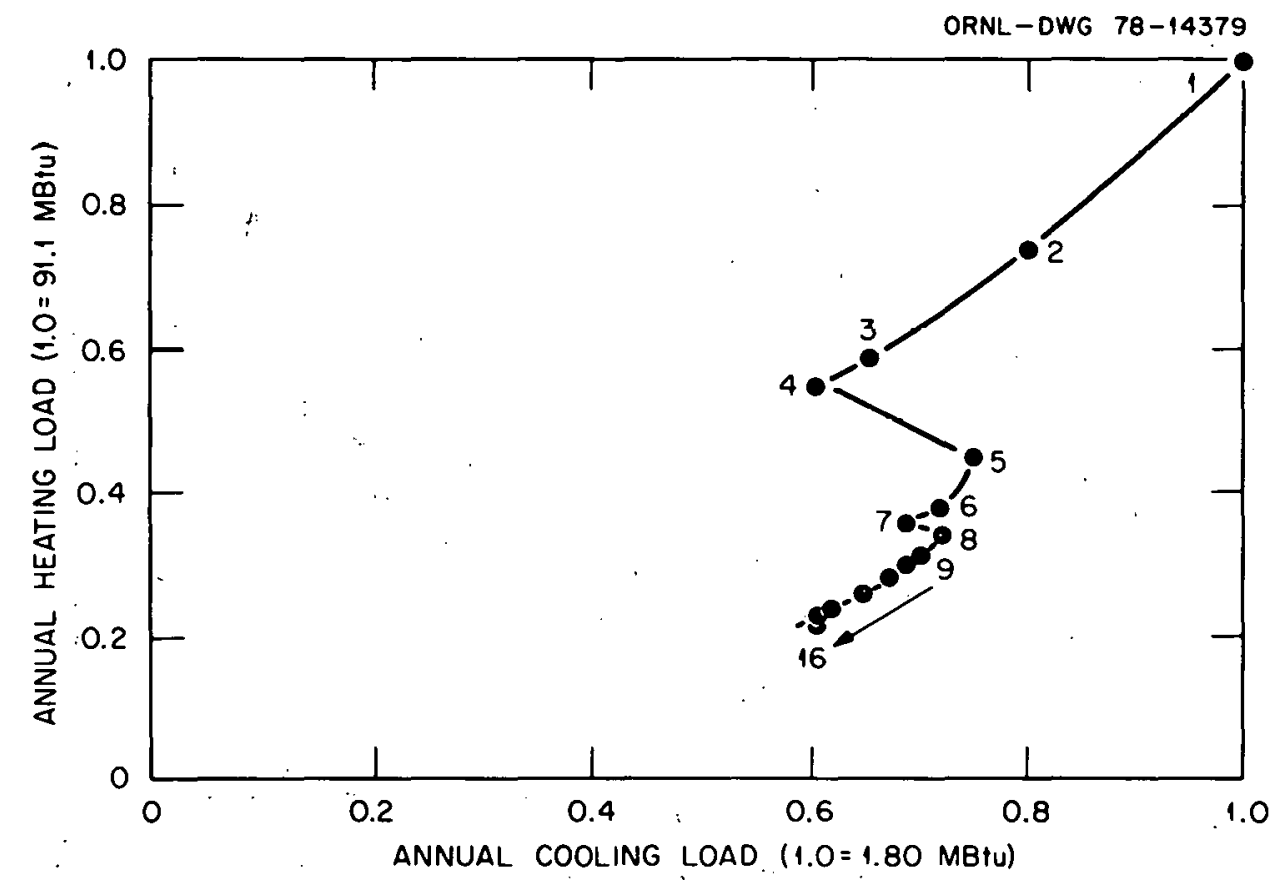

Fig. A-12. Heating/Cooling Load Relationship - Seattle. 


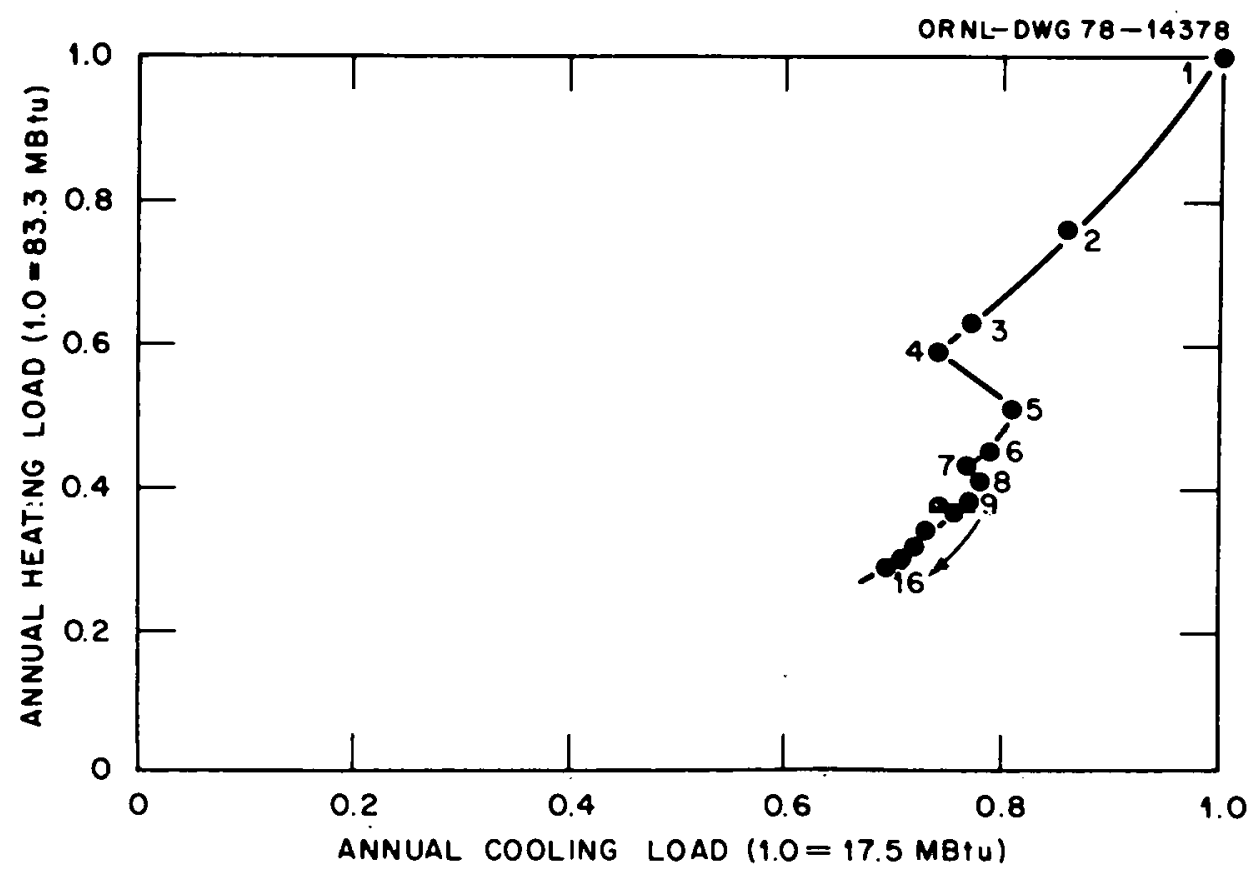

Fig. A-13. Heating/Cooling Load Relationship - Kansas City.

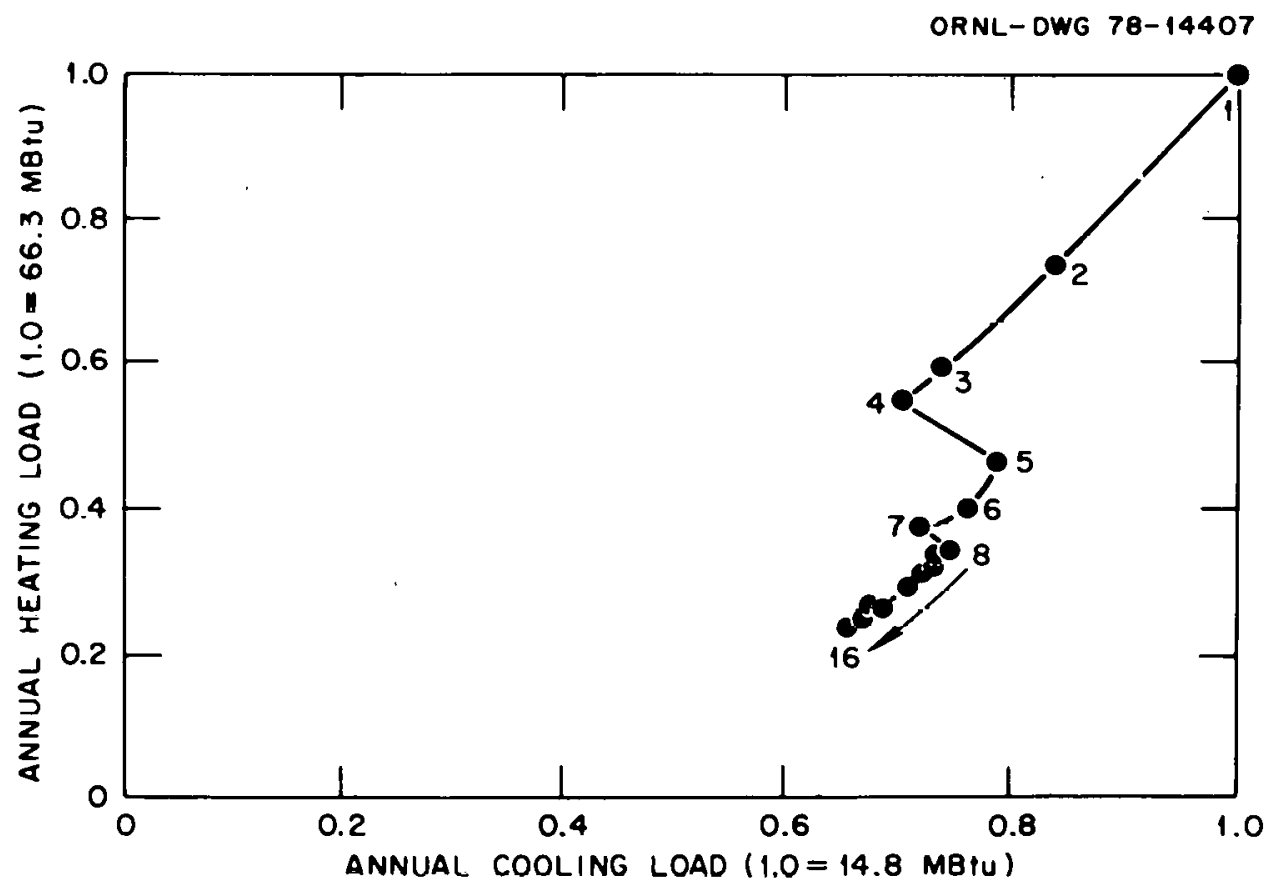

Fig. A-14. Heating/Cooling Load Relationship - Washington, D.C. 


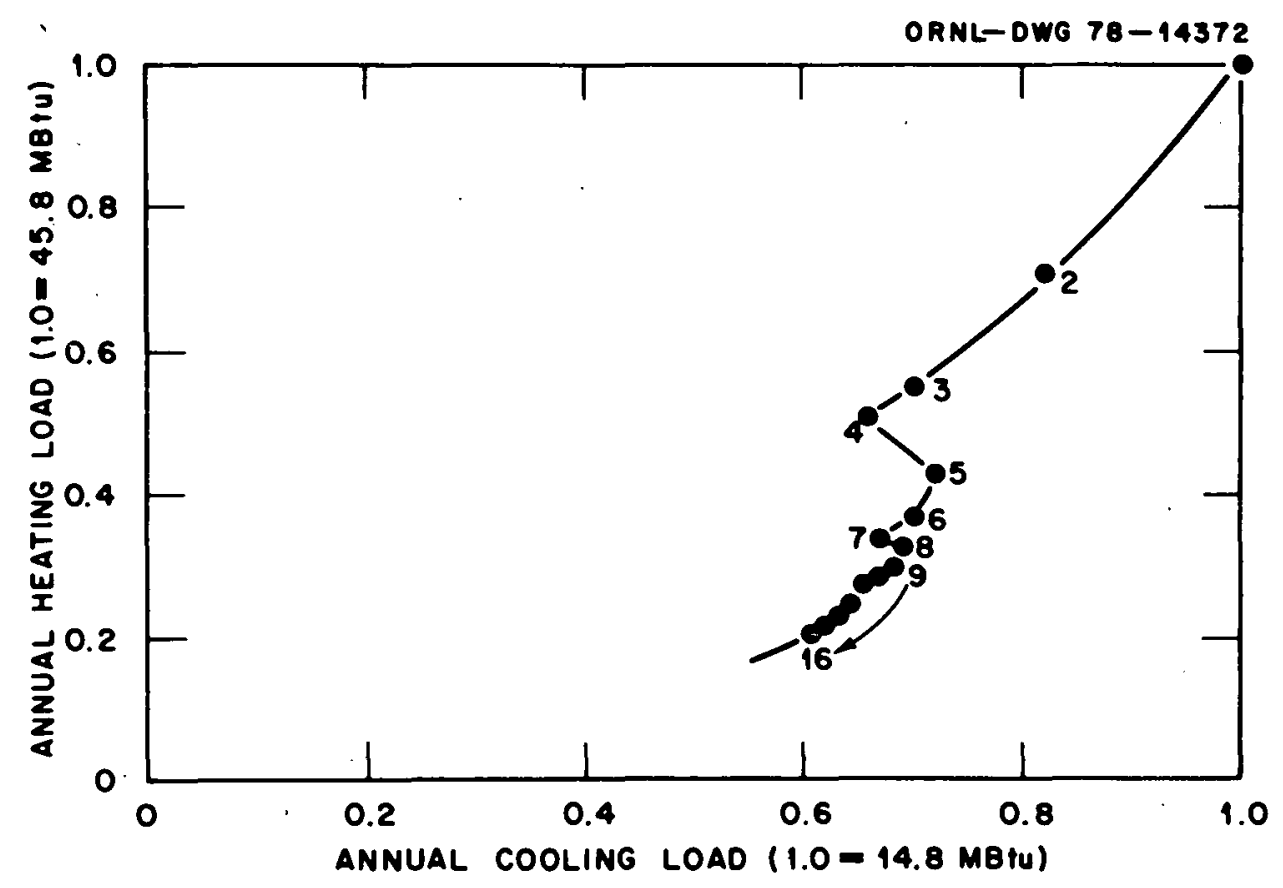

Fig. A-15. Heating/Cooling Load Relationship - Atlanta.

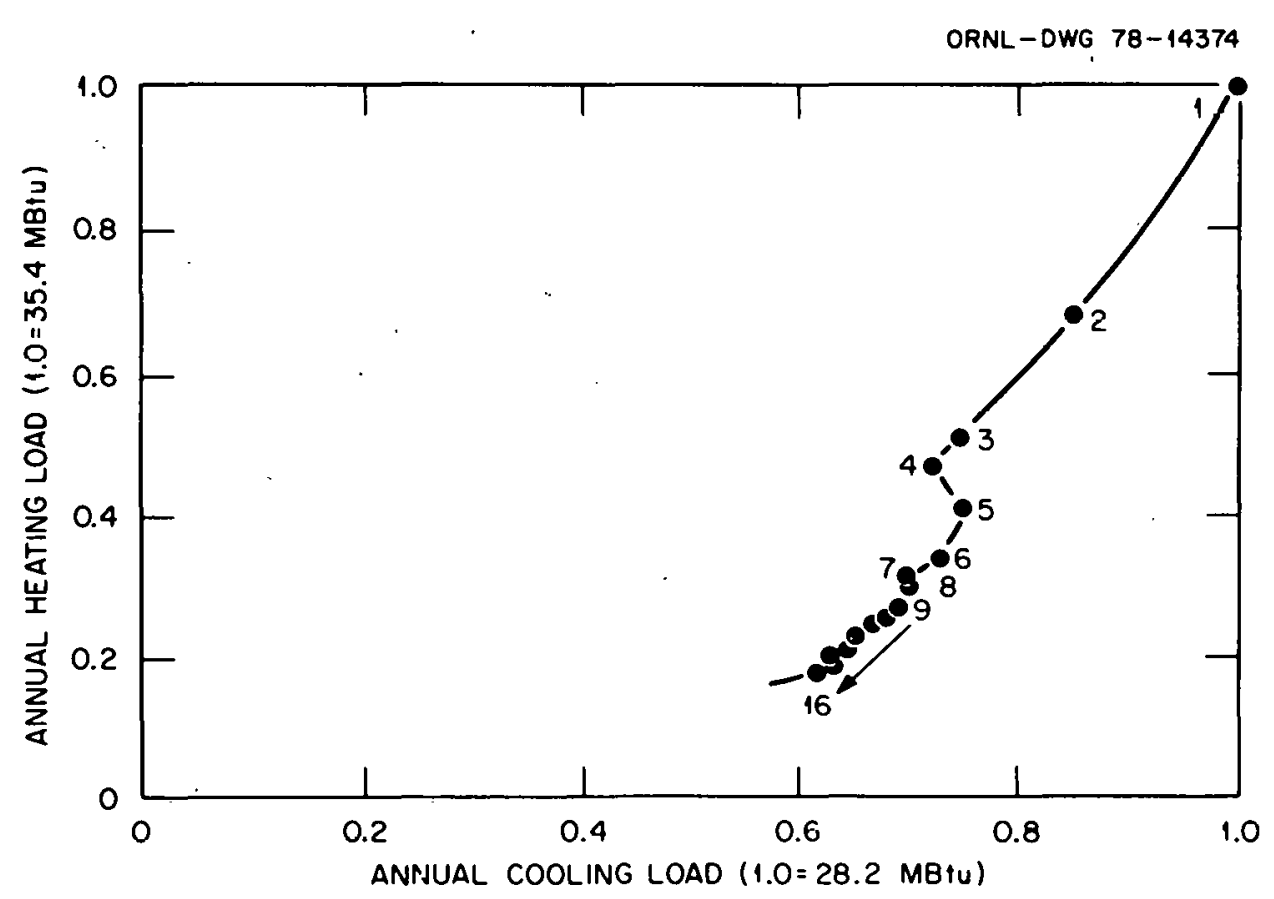

Fig. A-16. Heating/Cooling Load Relationship - Fort Worth. 


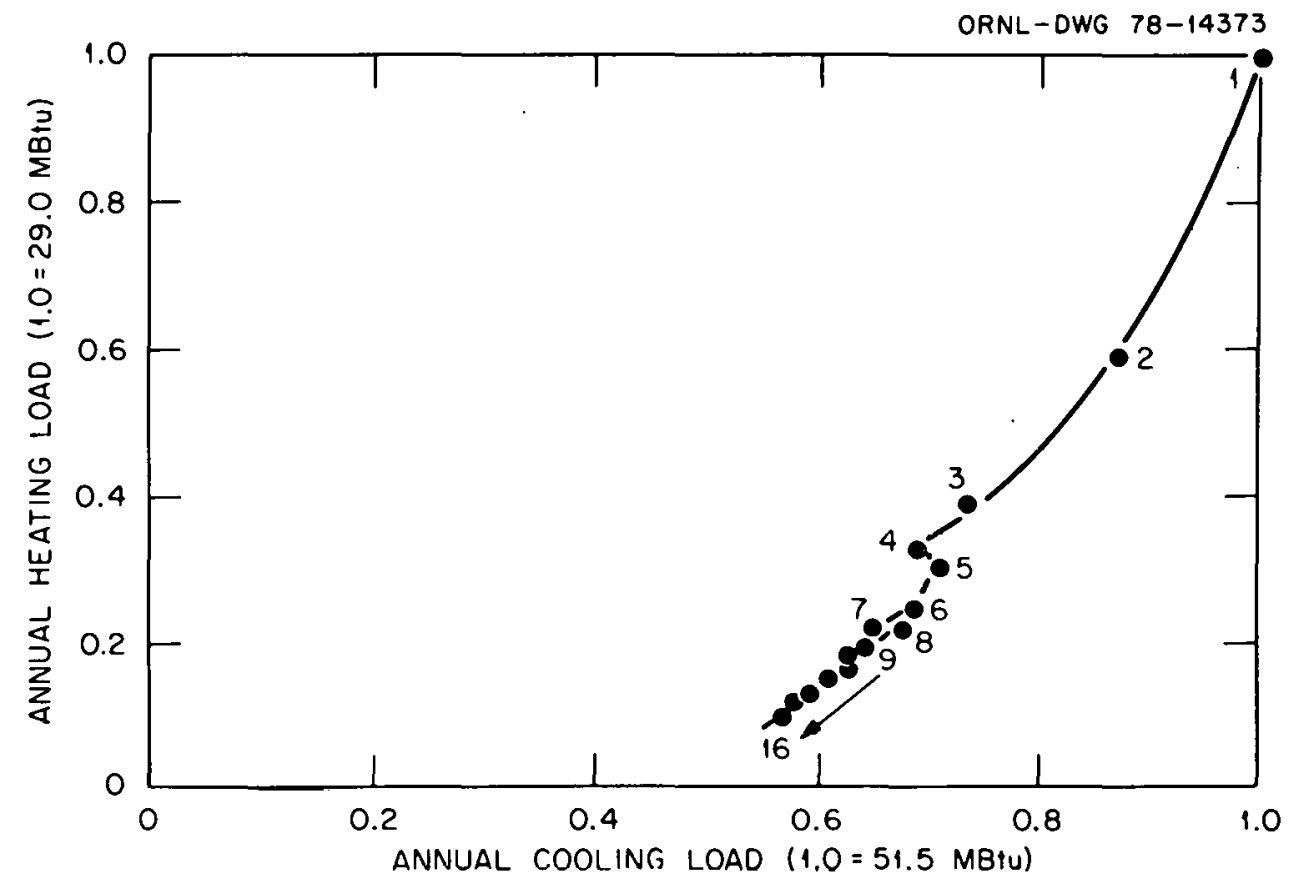

Fig. A-17. Heating/Cooling Load Relationship - Phoenix.

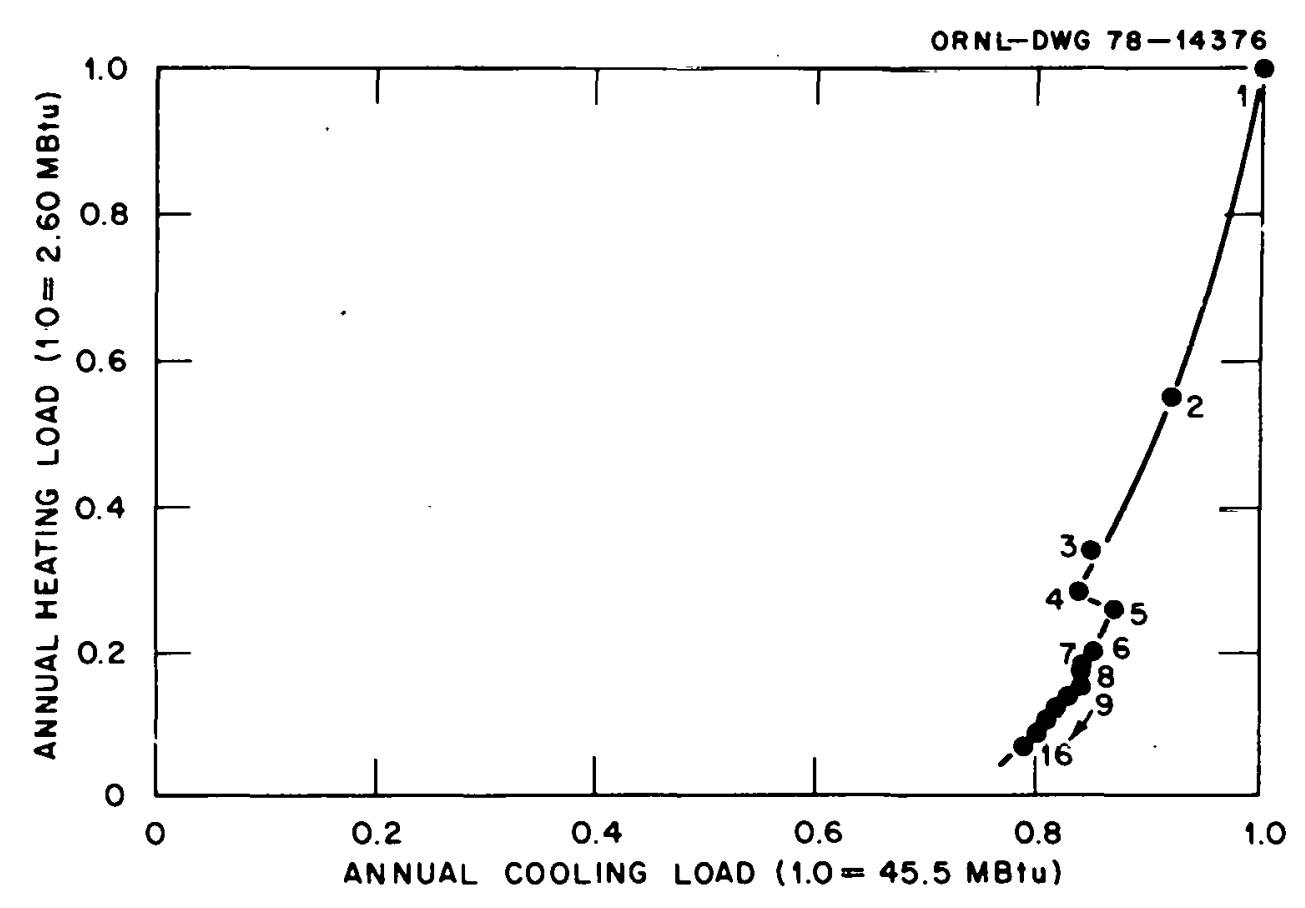

Fi.g. A-18. Heating/Cooling Load Relationship - Miami. 
Table A-1. NBSLD load calculation results - Minneapolis

\begin{tabular}{|c|c|c|c|c|c|c|c|}
\hline \multirow{2}{*}{$\begin{array}{l}\text { Design } \\
\text { option }\end{array}$} & \multirow{2}{*}{$\begin{array}{l}\text { Additional } \\
\text { feature }\end{array}$} & \multicolumn{2}{|c|}{ Annual loads (MBtu) } & \multicolumn{2}{|c|}{$\begin{array}{l}\text { Peak demands } \\
\qquad(\mathrm{kBtu} / \mathrm{hr})\end{array}$} & \multicolumn{2}{|c|}{$\begin{array}{l}\text { Additional initial } \\
\text { cost }(1975-\$)^{\star}\end{array}$} \\
\hline & & Heating & Cooling & Heating & Cooling & Heat on $1 y$ & Heat $+A / C$ \\
\hline 1 & Baseline & 143.5 & 9.5 & 81.9 & 23.7 & 0. & 0. \\
\hline 2 & R-11 attic ins. & 114.7 & 7.9 & 67.9 & $21 \cdot 1$ & 131 & 71. \\
\hline 3 & R-11 wall ins. & 56.6 & 6.9 & 59.2 & $19 \cdot 3$ & 262 . & 161. \\
\hline 4 & R-19 attic ins. & 91.7 & 6.5 & 56.8 & 18.4 & 332 . & 211. \\
\hline 5 & R-11 floor ins. & 81.1 & 7.5 & 53.5 & 19.4 & 517 . & 419 \\
\hline 6 & Storm windows & 73.0 & $7 \cdot 3$ & $49 \cdot 8$ & $17 \cdot 7$ & 665 . & 527 . \\
\hline 7 & R-30 attic ins. & 65.7 & 7.1 & 48.1 & 16.0 & 778 . & 601. \\
\hline 8 & R-19 floor ins. & 67.3 & 7.2 & $47 \cdot 1$ & $17 \cdot 3$ & 861. & 724. \\
\hline 9 & 2-paned SGD & $63 \cdot 8$ & $7 \cdot 1$ & 45.5 & 16.0 & 983. & 806. \\
\hline 10 & R-13 wall ins. & 62.7 & 7.0 & 44.9 & $15 \cdot 5$ & 1031 & 843 \\
\hline 11 & R-38 attic ins. & 61.3 & 6.9 & $44 \cdot 3$ & $25 \cdot 2$ & 1105. & 910. \\
\hline 12 & R-19 wall Ins. & $5 \varepsilon \cdot 3$ & $6 \cdot 7$ & 42.8 & 14.7 & 1302 & 1095. \\
\hline 13 & 3-paned windows & 55.4 & 6.6 & 41.4 & 14.4 & 1473 & 1259 \\
\hline 14 & R-49 attic ins. & 54.4 & $6 \cdot 5$ & 40.9 & 14.2 & 1589. & 1370 \\
\hline 15 & Srorm door & 53.7 & 6.5 & 40.6 & $14 \cdot 2$ & 1695 & 1477 \\
\hline 16 & R-23 wa11 ins. & 51.8 & 6.4 & 39.6 & 14.0 & 1893 & 1670. \\
\hline
\end{tabular}

Table A-2. NBSLD load calculation results - Boston

\begin{tabular}{|c|c|c|c|c|c|c|c|}
\hline \multirow{2}{*}{$\begin{array}{l}\text { Design } \\
\text { option }\end{array}$} & \multirow{2}{*}{$\begin{array}{l}\text { Add1tional } \\
\text { feacul'e }\end{array}$} & \multicolumn{2}{|c|}{ Annual loads (MBtu) } & \multicolumn{2}{|c|}{$\begin{array}{l}\text { Peak demands } \\
\text { (kBtu/hr) }\end{array}$} & \multicolumn{2}{|c|}{$\begin{array}{l}\text { Additional Initial } \\
\text { coct }(1975-\$)^{\star}\end{array}$} \\
\hline & & Ileating & Cooling & Heating & Cooling & Heat only & Heat $+\mathrm{A} / \mathrm{C}$ \\
\hline 1 & Baseline & 98.8 & 5.1 & 55.2 & $21 \cdot 5$ & 0. & 0. \\
\hline 2 & $\mathrm{R}-11$ attic ins. & 77.0 & 4.4 & 45.0 & $.18 \cdot 2$ & 139 & 63 \\
\hline 3 & k-11 wall 1ns. & 63.9 & 3.9 & 39.0 & $15 \cdot 8$ & 276 & 145 \\
\hline 4 & $\mathrm{R}-19$ attic ins. & 60.4 & $3 \cdot 7$ & 37.4 & $15 \cdot 0$ & 345. & 198 \\
\hline 5 & R-Il floor Ins. & 50.9 & $4 \cdot 3$ & 34.9 & 16.1 & 534 . & 410 \\
\hline 6 & Storm windows & 44.8 & $4 \cdot 2$ & $32 \cdot 1$ & $15 \cdot 5$ & 684. & 546 \\
\hline 7 & $\mathrm{R}-30$ attic ins. & 42.2 & 4.1 & 31.0 & 14.8 & 798 . & 644. \\
\hline 8 & $\mathrm{R}-19$ floor ins. & 40.4 & 4.2 & 30.1 & 15.4 & 881 & 741. \\
\hline 9 & 2-paned SGD & 37.8 & 4.1 & 29.0 & 14.9 & 1004 & 252. \\
\hline 10 & $\mathrm{R}-13$ wàll ins. & 37.0 & 4.0 & 28.6 & $14 \cdot 8$ & 1053 & 899. \\
\hline 11 & $\mathrm{R}-38$ attic ins. & $3 \epsilon .0$ & $4 \cdot 0$ & $28 \cdot 2$ & 14.5 & 1127 & 966. \\
\hline 12 & $\mathrm{R}-19$ wall ins. & $3 \equiv \bullet 7$ & $3 \cdot 9$ & 27.0 & $14 \cdot 1$ & $1 \geq 25$. & 1155 \\
\hline 13 & 3-paned windows & $31 \cdot 8$ & $3 \cdot 8$ & 26.1 & $13 \cdot 8$ & 1497 & 1320 \\
\hline 14 & $\mathrm{R}-49$ attic ins. & 31.0 & 3.8 & 25.8 & 13.6 & 1613. & 1432 \\
\hline 15 & Storm door & 30.5 & $3 \cdot 8$ & 25.5 & 13.6 & 1720 & 1538 \\
\hline 16 & $\mathrm{R}-23$ wall ins. & $2 s \cdot 2$ & $3 \cdot 7$ & 24.9 & 13.5 & 1918 & 1734. \\
\hline
\end{tabular}

* These figures include labor and material costs less savings due to HVAC equipment size reductions. 
Table A-3. NBSLD load calculation results - Seattle

\begin{tabular}{|c|c|c|c|c|c|c|c|}
\hline \multirow{2}{*}{$\begin{array}{l}\text { Design } \\
\text { option }\end{array}$} & \multirow{2}{*}{$\begin{array}{l}\text { Additional } \\
\text { feature }\end{array}$} & \multicolumn{2}{|c|}{ Annual loads (MBtu) } & \multicolumn{2}{|c|}{$\begin{array}{l}\text { Peak demands } \\
(\mathrm{kBtu} / \mathrm{hr})\end{array}$} & \multicolumn{2}{|c|}{$\begin{array}{l}\text { Additional inftial } \\
\operatorname{cost}(1975-\$)^{\star}\end{array}$} \\
\hline & & Heating & Cooling & Heating & Cooling & Heat only & Heat $+\mathrm{A} / \mathrm{C}$ \\
\hline 1 & Baseline & 91.1 & 1.8 & 37.6 & 25.0 & $\therefore 0$. & 0. \\
\hline 2 & R-11 attic ins. & 67.5 & 1.4 & 30.0 & 19.3 & 144 & 13. \\
\hline 3 & R-11 wall ins. & $5 \geq .7$ & 1.2 & 25.6 & 15.2 & 285 & 59. \\
\hline 4 & $\mathrm{R}-19$ attic ins. & 50.0 & 1.1 & 24.4 & 13.9 & 357 . & 102. \\
\hline 5 & R-11 floor ins. & 41.2 & $1 \cdot 3$ & 23.0 & 15.4 & 547. & 326. \\
\hline 6 & Storm windows & $3 \leq .1$ & $1 \cdot 3$ & $21 \cdot 0$ & 14.5 & 697. & 455. \\
\hline 7 & R-30 attic ins. & $3<\cdot 0$ & $1 \cdot 3$ & $2 n \cdot 2$ & 13,7 & 812 . & $5 \subseteq 3$ \\
\hline 8 & R-19 floor ins. & 30.8 & $1 \cdot 3$ & $19 \cdot 4$ & 14.5 & 896. & 554. \\
\hline 9 & 2-paned SGD & $2 \varepsilon \cdot 2$ & $1 \cdot 3$ & 18.6 & $13 \cdot 7$ & 1019 & 759. \\
\hline 10 & R-13 wall ins. & 27.4 & $1 \cdot 3$ & 18.4 & 13.7 & 1069 & 809 \\
\hline 11 & R-38 attic ins. & $2 \epsilon \cdot 4$ & 1.2 & 18.0 & $13 \cdot 3$ & 1143 & 874 \\
\hline 12 & R-19 wall ins. & $24 \cdot 1$ & 1.2 & $17 \cdot 2$ & 12.7 & 1341 . & 1058 \\
\hline 13 & 3-paned windows & 22.2 & 1.1 & 16.4 & 12.2 & 1514 & 1219 \\
\hline 14 & R- 49 attic ins. & 21.4 & 1.1 & 16.1 & 12.0 & $1630^{\circ}$ & 1331 . \\
\hline 15 & Storm door & 21.0 & $1 \cdot 1$ & 16.0 & 12.0 & 1737 & 1438 \\
\hline 16 & R-23 wall ins. & 15.6 & 1.1 & 15.7 & 12.0 & 1930 . & $1 \in 3 ?$. \\
\hline
\end{tabular}

Table A-4. NBSLD load calculation results - Kansas Cicy

\begin{tabular}{|c|c|c|c|c|c|c|c|}
\hline \multirow{2}{*}{$\begin{array}{l}\text { Design } \\
\text { option }\end{array}$} & \multirow{2}{*}{$\begin{array}{l}\text { Additional } \\
\text { feature }\end{array}$} & \multicolumn{2}{|c|}{ Annual loads (MBtu) } & \multicolumn{2}{|c|}{$\begin{array}{l}\text { Peak demands } \\
\qquad(k B t u / h r)\end{array}$} & \multicolumn{2}{|c|}{$\begin{array}{l}\text { Additional initial } \\
\operatorname{cost}(1975-\$)^{\star}\end{array}$} \\
\hline & & Heating & Cooling & Heating & Cooling & Heat only & Heat $+A / C$ \\
\hline 1 & Baseline & 83.3 & 17.5 & 66.8 & 29.2 & 0. & 0. \\
\hline 2 & R-11 atric ins. & 63.7 & 15.0 & $54 \cdot 1$ & 23.5 & 133. & 2 \\
\hline 3 & R-11 wall ins. & 52.3 & 13.5 & 46.8 & $20 \cdot 1$ & 268. & 99. \\
\hline 4 & R-19 attic ins. & $45 \cdot 2$ & 12.9 & 44.7 & 18.7 & 339 . & $9 ?$. \\
\hline 5 & $\mathrm{R}-11$ floor ins. & $4 z \cdot 6$ & 14.2 & 42.6 & 19.5 & 526 & 303. \\
\hline 6 & Storm windows & 37.6 & 13.9 & $37 \cdot 8$ & 19.0 & 671. & 436 \\
\hline 7 & R-30 attic ins. & 35.5 & 13.4 & 36.9 & 16.1 & 786. & $\leq \Xi 1$. \\
\hline-8 & R-19 floor ins. & 34.0 & 13.6 & $36 \cdot 3$ & 18.4 & 870. & 621 \\
\hline 9 & 2-paned $s G \mathrm{~V}$ & 32.0 & $13 \cdot 4$ & $35 \cdot 3$ & $18 \cdot 1$ & 993. & 738 \\
\hline 10 & R-13 wa11 ins. & 31.2 & $13 \cdot 3$ & $3 b .1$ & 17.9 & 1042. & 783. \\
\hline 11 & R-38 attic ins. & 30.5 & $13 \cdot 2$ & $34 \cdot 7$ & 17.7 & 1117 & $\varepsilon \subseteq 2$ \\
\hline 12 & n- 19 wall ins. & 28.4 & $12 \cdot 8$ & 33.2 & $17 . ?$ & 1313. & 1037 \\
\hline 13 & 3-paned windows & $2 \epsilon \cdot 8$ & $12 \cdot 6$ & $32 \cdot 1$ & 16.9 & 1485 & 1202 \\
\hline 14 & R-49 attic ins. & $2 \in \cdot 1$ & 12.4 & $31 \cdot 5$ & 16.6 & 1601. & 1311. \\
\hline 15 & Storn door & 25.7 & $12 \cdot 4$ & $31 \cdot 2$ & 16.6 & 1707 . & 1418. \\
\hline 16 & k-23 wa11 Ins. & 20.6 & 12.3 & 30.4 & 16.5 & 1906 & 1613 \\
\hline
\end{tabular}

* These figures include labor and material costs less savings due to HVAC equipment size reductions. 
Table A-5. NBSLD load calculation results - Washington, D.C.

\begin{tabular}{|c|c|c|c|c|c|c|c|c|}
\hline \multirow{2}{*}{$\begin{array}{l}\text { Design } \\
\text { option }\end{array}$} & \multirow{2}{*}{$\begin{array}{l}\text { Additional } \\
\text { feature }\end{array}$} & \multicolumn{2}{|c|}{ Annual loads (MBtu) } & \multicolumn{2}{|c|}{$\begin{array}{c}\text { Peak demands } \\
(\mathrm{kBtu} / \mathrm{hr})\end{array}$} & & \multicolumn{2}{|c|}{$\begin{array}{l}\text { Additional Initial } \\
\text { cost }(1975-\$)^{*}\end{array}$} \\
\hline & & Heating & Cooling & Heating & Cooling & & Heat only & Heat $+\mathrm{A} / \mathrm{C}$ \\
\hline 1 & Baseline & 66.3 & 14.8 & 32.7 & 43.4 & & 0. & 0. \\
\hline 2 & R-11 attic ins. & $\Delta S .1$ & 12.4 & 23.6 & $35 \cdot 3$ & $\cdot$ & 141. & -45 \\
\hline 3 & $\mathrm{R}-11$ wall ins. & 39.5 & 10.9 & $18 \cdot 1$ & 30.7 & & 279. & $-1 \geq$ \\
\hline$: 4$ & R-19 attic ins. & $3 \epsilon .7$ & 10.3 & 16.6 & 29.4 & & 351 . & 29. \\
\hline 5 & R-11 floor ins. & 30.6 & 11.5 & 17.5 & $27 \cdot 5$ & & 545 . & 180 \\
\hline 6 & Storm windows & $2 \epsilon .5$ & 11.2 & 16.8 & $25 \cdot 3$ & & 699. & 282 . \\
\hline 7 & R-30 attic ins. & 24.8 & 10.8 & 15.9 & 24.4 & & 314. & 377 . \\
\hline 8 & R-19 floor ins. & 23.5 & 11.0 & $16 \cdot 3$ & 23.7 & & 900 . & 447. \\
\hline 9 & 2-paned SGD & 21.8 & 10.8 & 15.9 & $22 \cdot 7$ & & 1024 . & 548. \\
\hline 10 & R-13 wall ins. & $21 \cdot 3$ & 10.8 & 15.9 & 22.5 & & 1074 . & 593. \\
\hline 11 & $\mathrm{R}-38$ attic ins. & 20.6 & 10.6 & $15 \cdot 3$ & $22 \cdot 1$ & & 1148. & 658 \\
\hline 12 & R-19 wall ins. & 18.9 & 10.3 & 14.8 & 21.2 & & 1347 & 836. \\
\hline 13 & 3-paned windows & 17.6 & 10.1 & 14.4 & 20.5 & & 1520 & 993. \\
\hline 14 & R-49 attic ins. & 17.0 & 9.9 & $14 \cdot 1$ & 20.2 & & 1636 & 1102 \\
\hline 15 & Storm door & $1 \epsilon .6$ & 9.9 & 14.1 & 20.0 & & 1743. & 1205 \\
\hline 16 & R-23 wall ins. & 15.7 & 9.8 & 13.9 & 19.5 & & 1943. & 1393. \\
\hline
\end{tabular}

${ }^{\star}$ These figures include labor and material costs less savings due to HVAC equipment size reductions.

Table A-6. NBSLD load calculation results - Atlanta

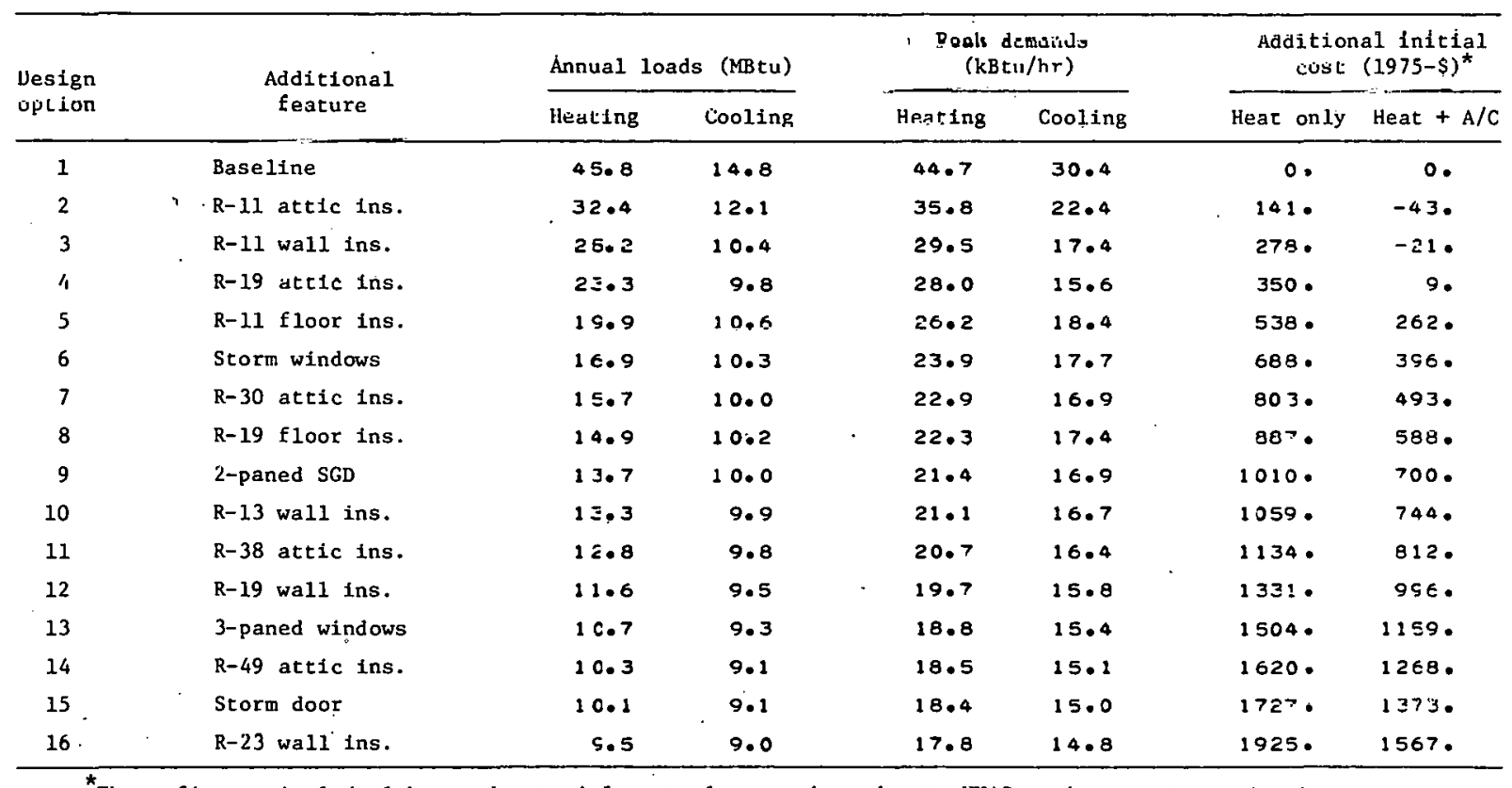

${ }^{\star}$ These figures include labor and material costs less savings due to HVAC equipment size reductions. 
Table A-7. NBSLD load calculation results - Fort Worth

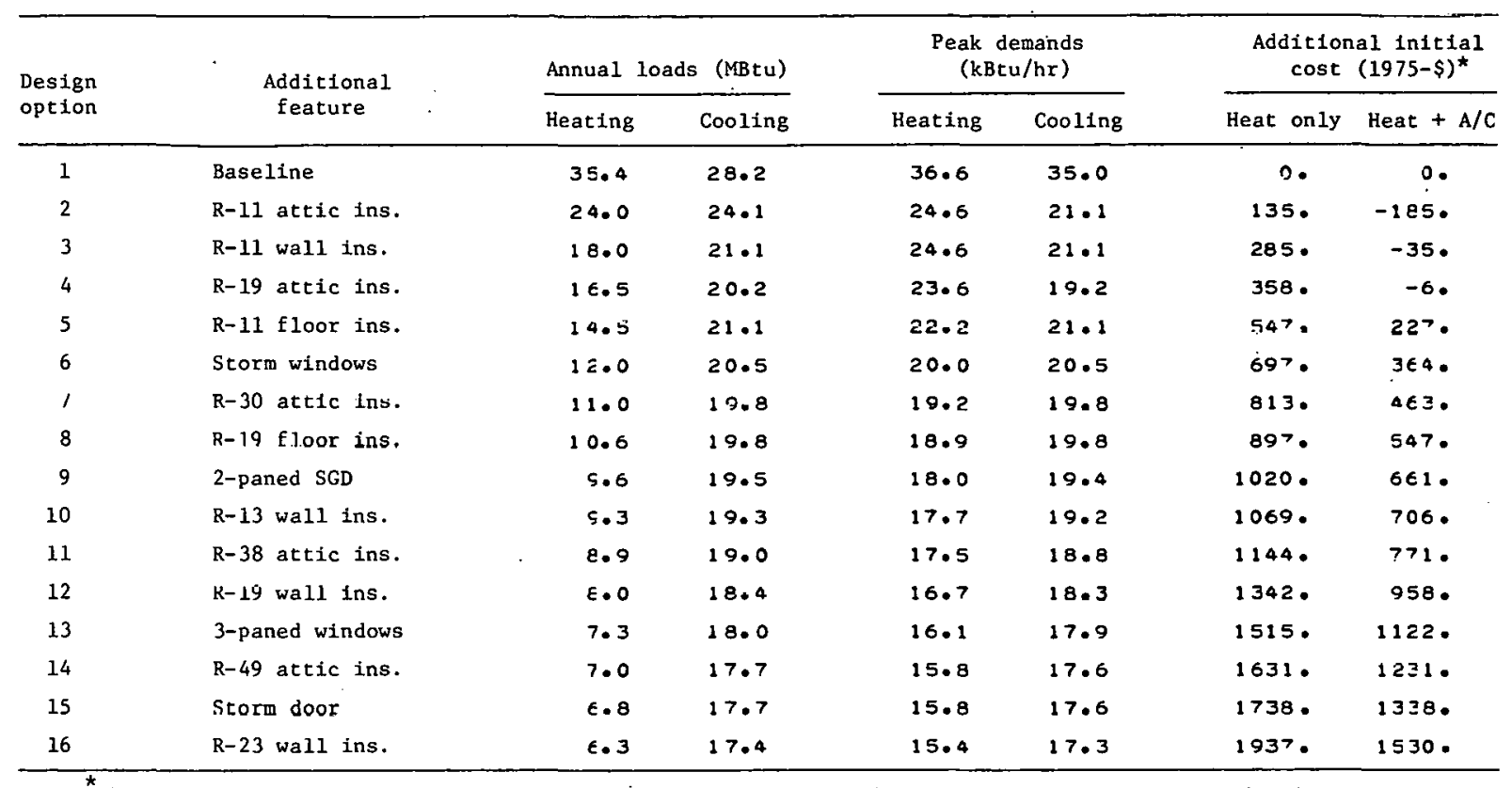

* These figures include labor and material costs less savings due to HVAC equipment size reductions.

Table A-8. NBSLD load calcul.ation results - Phoenix

\begin{tabular}{|c|c|c|c|c|c|c|c|}
\hline \multirow{2}{*}{$\begin{array}{l}\text { Design } \\
\text { option }\end{array}$} & \multirow{2}{*}{$\begin{array}{l}\text { Additional } \\
\text { feature }\end{array}$} & \multicolumn{2}{|c|}{ Annual loads (MBtu) } & \multicolumn{2}{|c|}{$\begin{array}{l}\text { Peak demands } \\
\text { (kBtu/hr) }\end{array}$} & \multicolumn{2}{|c|}{$\begin{array}{c}\text { Additional initial } \\
\text { cost }(1975-\$)^{\star}\end{array}$} \\
\hline & & Heating & Cooling & Heating & Cooling & Heat only & Heat $+\mathrm{A} / \mathrm{C}$ \\
\hline 1 & Baseline & 29.0 & 51.5 & $29 \cdot 1$ & $39 \cdot 2$ & 0. & 0. \\
\hline 2 & R-11 attic ins. & 17.2 & 44.6 & $21 \cdot 1$ & $31 \cdot 2$ & 143 & -41 \\
\hline 3 & $\mathrm{R}-11$ wall iins: & 11.2 & 37.6 & 17.1 & $23 \cdot 2$ & 285 & -93 \\
\hline 4 & R-19 attic ins. & 5.5 & 35.5 & 16.0 & 21.0 & 357. & -61 \\
\hline 5 & R-11 floor ins. & S. 1 & 36.7 & 15.4 & $22 \cdot 3$ & 548 & 160. \\
\hline 6 & Storm windows & $7 \cdot 2$ & $35 \cdot 3$ & $13 \cdot 7$ & $22 \cdot 3$ & 700 & $\geq 11$. \\
\hline 7 & $\mathrm{R}-30$ attic inc. & $\epsilon .5$ & $34 \cdot 8$ & 12.9 & $22 \cdot 3$ & 815. & 426 \\
\hline 8 & R-19 floor ins. & $\epsilon \cdot 2$ & 33.7 & $12 \cdot 8$ & $22 \cdot 3$ & 900 . & 511. \\
\hline 9 & 2-paned SGD & 5.5 & 32.9 & 12.1 & $22 \cdot 4$ & 1023 & $E \geq 7$ \\
\hline 10 & R-13 wall ine. & $5 . .3$ & 32.7 & $12 \cdot 0$ & $22 \cdot 4$ & 1073 & $6 \varepsilon 7$. \\
\hline 11 & R-38 attic ins. & $5 \cdot 0$ & $32 \cdot 5$ & $11 \cdot 5$ & $22 \cdot 4$ & 1147 & $7 \in 1$. \\
\hline 12 & R-19 wa 11 ins. & $4 \cdot 3$ & 31.6 & 10.7 & 22.0 & 1345 & 950. \\
\hline 13 & 3-paned windows & $3 \cdot 7$ & 30.4 & 10.2 & 21.5 & 1518. & 1111. \\
\hline 14 & R-49 attic ins. & $3 \cdot 5$ & 30.0 & 10.0 & $21 \cdot 3$ & 1635 & 1223 \\
\hline 15 & Storm door & 3.4 & 29.8 & 9.8 & $21 \cdot 2$ & 1741 & $1 \geq 27$ \\
\hline 16 & R-23 wall ins. & 3.0 & 29.4 & $9 \cdot 3$ & 21.0 & 1941 & $1 \leq 22$ \\
\hline
\end{tabular}

* These figures include labor and material costs less savings due to llvac cquipment s1za reducticuss. 
Table A-9. NBSLD load calculation results - Miami

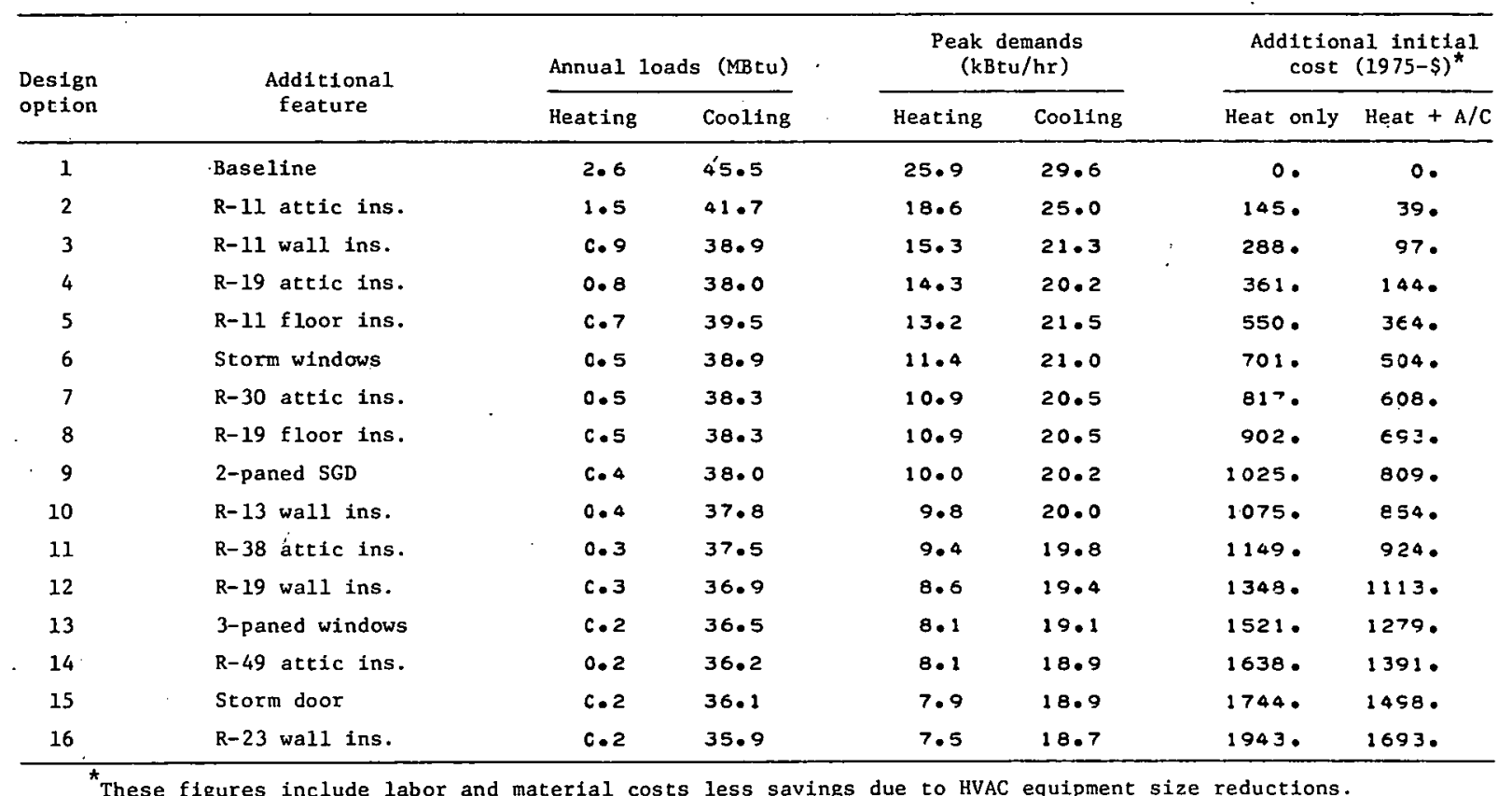

*These figures include labor and material costs less savings due to HVAC equipment size reductions.

Table A-10. Economic analysis results - Minneapolis

\begin{tabular}{|c|c|c|c|c|c|c|c|c|c|}
\hline \multirow{3}{*}{$\begin{array}{l}\text { Design } \\
\text { option }\end{array}$} & & \multicolumn{4}{|c|}{ Natural gas heating } & \multicolumn{4}{|c|}{ Electric heating } \\
\hline & & \multicolumn{2}{|c|}{ No $A j \mathrm{C}^{\mathrm{*}}$. } & \multicolumn{2}{|c|}{ With $\dot{A} / C^{x}$} & \multicolumn{2}{|c|}{ No $A / C^{\star}$} & \multicolumn{2}{|c|}{ With $A / C^{*}$} \\
\hline & . & $\begin{array}{c}\mathrm{NPW}^{\dagger} \\
(1975-\$)\end{array}$ & $\begin{array}{c}P D^{\ddagger} \\
\text { (years) }\end{array}$ & $\begin{array}{c}\mathrm{NPW}^{\dagger} \\
(1975-\$)\end{array}$ & $\begin{array}{c}\mathrm{PB}^{\text {\# }} \\
\text { (years) }\end{array}$ & $\begin{array}{c}\mathrm{NLW}^{\dagger} \\
(1975-\$)\end{array}$ & $\begin{array}{c}\mathrm{PB}^{\text {\# }} \\
\text { (years) }\end{array}$ & $\begin{array}{c}\mathrm{NPW}^{\dagger} \\
(1975-\$)\end{array}$ & $\begin{array}{c}\mathrm{PB}^{\ddagger} \\
\text { (years) }\end{array}$ \\
\hline 1 & & 0. & 0.0 & 0. & 0.0 & 0. & 0.0 & 0. & 0.0 \\
\hline 2 & & 1354. & $1: 3$ & 1530 & 0.6 & 0303. & 0.5 & 4479. & 0.2 \\
\hline 3 & & 2156. & 1.6 & 2450 & 0.9 & 6958 & 0.6 & 7252 & 0.3 \\
\hline 4 & $\cdot$ & 2338 & $1 \cdot 9$ & 2681 . & $1 \cdot 1$ & 7641 & 0.6 & $7984:$ & 0.4 \\
\hline 5 & & $26 \subseteq 8$ & $2 \cdot 4$ & 2945 & 1.9 & 9086. & 0.8 & ฯコココ. & 0.7 \\
\hline 6 & & 2967 & $2 \cdot 8$ & 3268 . & $2 \cdot 1$ & 10183 & 0.9 & 10484 & 0.7 \\
\hline 7 & & 3024 & $3 \cdot 1$ & 3382 . & $2 \cdot 3$ & 10578 & $1 \cdot 1$ & 10535 & 0.8 \\
\hline 8 & & $30 \in 4$ & $3 \cdot 3$ & 3380. & $2 \cdot 6$ & 10863 & $1 \cdot 1$ & 11179. & 0.9 \\
\hline 9 & & 3119. & 3.6 & 3474 . & 2.8 & 11267 & $1 \cdot 2$ & $11 \in 22$ & 1.0 \\
\hline 10 & & 3129. & 3.8 & 3501 . & $2 \cdot 9$ & 11393. & $1 \cdot 3$ & 11766 & 1.0 \\
\hline 11 & . & 3125 & 4.0 & 3511. & 3.1 & 11530 & $1 \cdot 3$ & $1151 \epsilon$. & $1 \cdot 1$ \\
\hline 12 & & $3 C E 7$ & $4 \cdot 5$ & 3502 & 3.6 & 11806 & 1.5 & $12 \approx 21$ & $1 \cdot 3$ \\
\hline 13 & & $3 c \in 3$ & $.4 \cdot 9$ & 34 S5. & 4.0 & 12073 & $1 . ?$ & $1250 \epsilon$ & 1.4 \\
\hline 14 & & 3000 & $5 \cdot 3$ & 3444 . & $4 \cdot 3$ & 12115 & 1.8 & 12559 & $1 \cdot 5$ \\
\hline 15 & & 2S28. & $5 \cdot 6$ & 3374 . & $4 \cdot 6$ & 12114. & 1.9 & $1 \approx 560^{\circ}$ & $1 \cdot 6$ \\
\hline 16 & & $2 \varepsilon \geq 0$ & $6 \cdot 1$ & 3286. & $5 \cdot 1$ & 12214. & 2.1 & $126 \in 9$. & 1.8 \\
\hline
\end{tabular}

${ }^{\star} \mathrm{A} / \mathrm{C}=$ air conditioning.

$t_{\mathrm{NPW}}=$ net present worth of savings.

${ }^{\text {F }} \mathrm{PB}=$ payback period. 
Table A-11. Economic arialysis results - Boston

\begin{tabular}{|c|c|c|c|c|c|c|c|c|}
\hline \multirow{3}{*}{$\begin{array}{l}\text { Design } \\
\text { option }\end{array}$} & \multicolumn{4}{|c|}{ Natural gas heating } & \multicolumn{4}{|c|}{ Electric heating } \\
\hline & \multicolumn{2}{|c|}{ No $A / C^{*}$} & \multicolumn{2}{|c|}{ With $A / C^{*}$} & \multicolumn{2}{|c|}{ No $A / C^{\star}$} & \multicolumn{2}{|c|}{ With $\mathrm{A} / \mathrm{C}^{*}$} \\
\hline & $\begin{array}{c}\mathrm{NPW}^{\dagger} \\
(1975-\$)\end{array}$ & $\begin{array}{c}\mathrm{PB}^{\ddagger} \\
\text { (years) }\end{array}$ & $\begin{array}{c}\mathrm{NPW}^{\dagger} \\
(1975-\$)\end{array}$ & 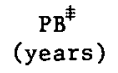 & $\begin{array}{c}\mathrm{NPW}^{\dagger} \\
(1975-\$)\end{array}$ & $\begin{array}{c}\mathrm{PB}^{\ddagger} \\
\text { (years) }\end{array}$ & $\begin{array}{c}\mathrm{NPW}^{\dagger} \\
(1975-\$)\end{array}$ & $\begin{array}{c}\mathrm{PB}^{\ddagger} \\
\text { (years) }\end{array}$ \\
\hline 1 & 0. & 0.0 & 0. & 0.0 & 0. & 0.0 & 0. & 0.0 \\
\hline 2 & SE 5. & $1 \cdot 8$ & 1117. & 0.8 & 3218 . & 0.6 & $\Xi \geq 50$. & 0.3 \\
\hline 3 & 1520. & $2 \cdot 3$ & 1746 . & $1 \cdot 1$ & 5088. & 0.8 & $5 \geq 13$. & 0.4 \\
\hline 4 & $1 \in 30$ & $2 \cdot 6$ & 1888 & $1 \cdot 4$ & 5560. & 0.9 & se17. & 0.5 \\
\hline 5 & 1933 & $3 \cdot 3$ & 2120 . & $2 \cdot 4$ & 6836 . & $1 \cdot 1$ & 7023 & 0.8 \\
\hline 6 & 2057 & $3 \cdot 7$ & 2306 & $2 \cdot 9$ & 7624. & $1 \cdot 3$ & フยココ. & 1.0 \\
\hline 7 & 2114. & $4 \cdot 2$ & 2348 & $3 \cdot 3$ & 7904 . & 1.4 & e 137. & $1 \cdot 1$ \\
\hline 8 & 2126. & 4.5 & 2338 & 3.7 & 8102 . & $1 \cdot 5$ & 2314 & $1 \cdot 3$ \\
\hline 9 & 2135. & $4 \cdot 9$ & 2365. & 4.0 & 8373 & $1 \cdot 6$ & $\varepsilon \in 02$. & $1 \cdot 4$ \\
\hline 10 & 2130 & $5 \cdot 0$ & 2364 & $4 \cdot 2$ & 8455 & $1 \cdot 7$ & ete9. & $1 \cdot 4$ \\
\hline 11 & 2106. & $5 \cdot 3$ & 2350. & $4 \cdot 4$ & 8531. & 1.8 & 2775. & 1.5 \\
\hline 12 & 2027 & 6.0 & 2290 & $5 \cdot 1$ & 8690. & 2.0 & 2952 . & $1 \cdot 8$ \\
\hline 13 & 1550. & 6.6 & $22 ? 6$. & $5 \cdot 7$ & 8799 . & $2 \cdot 2$ & SO75. & $2 \cdot 0$ \\
\hline 14 & 1877 & $7 \cdot 1$ & 2160 & $6 \cdot 1$ & 8814. & $2 \cdot 4$ & SOSP. & $2 \cdot 1$ \\
\hline 15 & 1756. & $7 \cdot 5$ & 2079 & 6.5 & 8783. & $2 \cdot 5$ & 9066 & $2 \cdot 2$ \\
\hline 16 & 1666 & $8 \cdot 2$ & 1955. & $7 \cdot 2$ & 8790. & 2.8 & $9 c 79$. & $2 \cdot 5$ \\
\hline
\end{tabular}

${ }_{\mathrm{A} / \mathrm{C}}=$ air conditioning.

${ }^{\dagger} \mathrm{NPW}$ - net precenc worll of savings.

${ }^{\ddagger} \mathrm{PB}=$ payback period.

Table A-12. Economic analysis results - Seattle

\begin{tabular}{|c|c|c|c|c|c|c|c|c|}
\hline \multirow{3}{*}{$\begin{array}{l}\text { Design } \\
\text { option }\end{array}$} & \multicolumn{4}{|c|}{ Natural gas heating } & \multicolumn{4}{|c|}{ Electric heating } \\
\hline & \multicolumn{2}{|c|}{ No $A / C^{\star}$} & \multicolumn{2}{|c|}{ With $A / C^{\star}$} & \multicolumn{2}{|c|}{ No $A / C^{\star}$} & \multicolumn{2}{|c|}{ With $\mathrm{A} / \mathrm{C}^{*}$} \\
\hline & $\begin{array}{c}\mathrm{NPW}^{\dagger} \\
(1975-\$)\end{array}$ & $\begin{array}{c}P^{\text {f }} \\
\text { (years) }\end{array}$ & $\begin{array}{c}\mathrm{NPW}^{\dagger} \\
(1975-\$)\end{array}$ & $\begin{array}{c}\mathrm{PB}^{\mp} \\
\text { (years) }\end{array}$ & $\begin{array}{c}\mathrm{NPW}^{\dagger} \\
(1975-\$)\end{array}$ & $\begin{array}{c}P B^{\ddagger} \\
\text { (years) }\end{array}$ & $\begin{array}{c}\mathrm{NPW}^{\dagger} \\
(1975-\$)\end{array}$ & $\begin{array}{c}\mathrm{PB}^{\text {₹ }} \\
\text { (years) }\end{array}$ \\
\hline 1 & 0. & 0.0 & 0. & 0.0 & 0. & 0.0 & 0. & 0.0 \\
\hline 2 & $1<\in 7$ & $1 \cdot 8$ & 1225 & 0.1 & 3478 & 0.6 & $\geq 0 \geq 0$. & 0.1 \\
\hline 3 & $1 \in 38$ & 2.2 & 1910 & 0.4 & 5465 & 0.8 & 5736 . & 0.2 \\
\hline 4 & 1755. & $2 \cdot 6$ & 2063. & 0.7 & 5951. & 0.9 & $\epsilon 268$ & 0.2 \\
\hline 5 & $201 \epsilon$ & $3 \cdot 2$ & 2271 . & $1 \cdot 9$ & 7119 & $1 \cdot 1$ & 7375 & 0.7 \\
\hline 6 & $21 \varepsilon 2$ & 3.7 & 2462 & $2 \cdot 4$ & 7916. & $1 \cdot 2$ & e196. & 0.8 \\
\hline 7 & 2154. & $4 \cdot 1$ & 2496 & 2.8 & 8180. & $1 \cdot 4$ & 2482 & 0.9 \\
\hline 8 & 2202 & $4 \cdot 4$ & 2482 & $3 \cdot 2$ & 8370 & 1.5 & $e \in 50$. & $1 \cdot 1$ \\
\hline 9 & 2212. & 4.8 & 2514. & $3 \cdot 5$ & 8647. & $1 \cdot 6$ & 8949 & $1 \cdot 2$ \\
\hline $10^{\circ}$ & 2205 & $5 \cdot 0$ & 2507 & 3.7 & 8724 . & 1.7 & 9026 & $1 \cdot 3$ \\
\hline 11 & 2180. & 5.3 & 2493 & $4 \cdot 0$ & 8797 & 1.8 & 9110 & $1 \cdot 3$ \\
\hline 12 & 2102 & 6.0 & 2433 & $4 \cdot 6$ & 8957. & $2 \cdot 0$ & $\$ 288$. & $1 \cdot 6$ \\
\hline 13 & 2028 & 6.5 & 2373 & $5 \cdot 2$ & 9080 & $2 \cdot 2$ & $\$ 425$. & 1.8 \\
\hline 14 & 1954 & 7.0 & 2306 & $5 \cdot 6$ & 9090. & $2 \cdot 3$ & 9441. & 1.9 \\
\hline 15 & $1 \in \in \mathbb{R}$ & $7 \cdot 4$ & 2220 & 6.0 & 9046 & 2.5 & $9 \pm 98$ & $2 \cdot 0$ \\
\hline 16 & 1739. & B. 1 & 2091 . & 6.7 & 9057. & $2 \cdot ?$ & 5409. & $2 \cdot 3$ \\
\hline
\end{tabular}

${ }^{\star} \mathrm{A} / \mathrm{C}=$ air conditioning.

${ }^{\dagger}$ NPW $=$ net present worth of savings.

${ }^{\text {F }}$ PB = payback period 
Table A-13. Economic analysis results - Kansas City

\begin{tabular}{|c|c|c|c|c|c|c|c|c|}
\hline \multirow{3}{*}{$\begin{array}{l}\text { Design } \\
\text { option. }\end{array}$} & \multicolumn{4}{|c|}{ Natural gas heating } & \multicolumn{4}{|c|}{ Electric heating } \\
\hline & \multicolumn{2}{|c|}{ No $A / C^{*}$} & \multicolumn{2}{|c|}{ With $\mathrm{A} / \mathrm{C}^{*}$} & \multicolumn{2}{|c|}{ No $A / C^{\star}$} & \multicolumn{2}{|c|}{ With $A / C^{*}$} \\
\hline & $\begin{array}{c}N P W^{\dagger} \\
(1975-\$)\end{array}$ & $\begin{array}{c}\mathrm{PB}^{\mathrm{F}} \\
\text { (years) }\end{array}$ & $\begin{array}{c}\mathrm{NPW}^{\dagger} \\
(1975-\$)\end{array}$ & $\begin{array}{c}\mathrm{PB}^{\text {F }} \\
\text { (years) }\end{array}$ & $\begin{array}{c}\mathrm{NPW}^{\dagger} \\
(1975-\$)\end{array}$ & $\begin{array}{c}\mathrm{PB}^{\text {夆 }} \\
\text { (years) }\end{array}$ & $\begin{array}{c}\mathrm{NPW}^{\dagger} \\
(1975-\$)\end{array}$ & $\begin{array}{c}\mathrm{PB}^{\ddagger} \\
\text { (years) }\end{array}$ \\
\hline 1 & 0. & 0.0 & o. & 0.0 & 0. & 0.0 & 0. & 0.0 \\
\hline 2 & e 80. & 1.9 & 1198. & -0.1 & 2886 & 0.7 & $\Xi 235$. & 0.0 \\
\hline 3 & 1330 & 2.5 & 1839 & 0.4 & 4496 & 0.9 & 5005 & 0.2 \\
\hline 4 & 1423. & 2.9 & 2009 & 0.6 & 4913 & $1 \cdot 0$ & 5499 & 0.3 \\
\hline 5 & 1574. & 3.8 & 2044 & 1.9 & 5738 . & 1.3 & $\epsilon 2 c 8$ & 0.7 \\
\hline 6 & 16.88. & 4.3 & 2192 & 2.5 & 6362 . & $1 \cdot 5$ & $\epsilon \varepsilon 66$ & 0.9 \\
\hline 7 & 1679 & 4.8 & 2242. & 2.9 & 6566 . & 1.6 & 7128 & 1.1 \\
\hline 8 & 1671. & 5.2 & 2212 & 3.3 & 6707 & 1.8 & 7248 & 1.2 \\
\hline 9 & 1655 & 5.7 & 2217 & 3.8 & 6903. & $3 \cdot 9$ & $74 \epsilon 5$. & 1.4 \\
\hline 10 & $1 \in 43$ & 5. 9 & 2217 . & 3.9 & 6956. & 2.0 & 7540. & 1.4 \\
\hline 11 & $1 \in 06$ & 6.3 & 2193. & $4 \cdot 2$ & 7004 . & 2.1 & 7551. & 1.6 \\
\hline 12 & 1516. & 7.1 & 2145 & 5.0 & 7126 & $2 \cdot 4$ & 7754. & $1 \cdot 8$ \\
\hline 13 & 1427. & 7.8 & 2077. & 5.6 & 7198. & 2.6 & 7248. & 2.0 \\
\hline 14 & 1349. & e. 3 & 2021. & 6.0 & 7195. & 2.8 & 7867. & 2.2 \\
\hline 15 & 1261. & 8.8 & 1933. & 6.5 & $7145 \bullet$ & 3.0 & วย1ร. & 2.4 \\
\hline 16 & 1120. & 9.6 & 1801 & 7.2 & 7115 & 3.2 & 7797. & 2.6 \\
\hline
\end{tabular}

${ }_{\mathrm{A}}^{\star} / \mathrm{C}=$ air conditioning.

${ }^{t_{\mathrm{NPW}}} \mathrm{C}_{\mathrm{i}}$ net present worth of savings.

${ }_{\mathrm{PB}}^{\ddagger}=$ payback period.

Table A-14. Economic analysis results - Washington, D.C.

\begin{tabular}{|c|c|c|c|c|c|c|c|c|}
\hline \multirow{3}{*}{$\begin{array}{l}\text { Design } \\
\text { option }\end{array}$} & \multicolumn{4}{|c|}{ Natural gas heating } & \multicolumn{4}{|c|}{ Ellertrif heatting } \\
\hline & \multicolumn{2}{|c|}{ No $A / C^{*}$} & \multicolumn{2}{|c|}{ With $A / C^{*}$} & \multicolumn{2}{|c|}{ No $A / C^{\star}$} & \multicolumn{2}{|c|}{ W1th $A / C^{*}$} \\
\hline & $\begin{array}{c}\mathrm{NPW}^{\dagger} \\
(1975-\$)\end{array}$ & $\begin{array}{c}\mathrm{PB}^{\text {₹ }} \\
\text { (years) }\end{array}$ & $\begin{array}{c}\mathrm{NPW}^{\dagger} \\
(1975-\$)\end{array}$ & $\begin{array}{c}\mathbf{P B}^{\neq} \\
\text {(years) }\end{array}$ & $\begin{array}{c}\mathrm{NPW}^{\dagger} \\
(1975-\$)\end{array}$ & $\begin{array}{c}P^{\ddagger}{ }^{\dagger} \\
\text { (years) }\end{array}$ & $\begin{array}{c}\mathrm{NPW}^{\dagger} \\
(1975-\$)\end{array}$ & $\begin{array}{c}\mathrm{PB}^{\neq} \\
\text {(years) }\end{array}$ \\
\hline 1 & 0. & 0.0 & 0. & 0.0 & 0. & 0.0 & 0. & 0.0 \\
\hline 2 & 743. & $2 \cdot 4$ & 1109 & -0.7 & 2497 . & 0.0 & $2 e \in 3$ & -0.2 \\
\hline 3 & 1101. & 3. 0 & 1685 & -0.2 & 3840. & 1.0 & 4424. & -0.0 \\
\hline 4 & 1172 & 3.5 & 1831 & 0.2 & 4194. & $1 \cdot 2$ & 4853 & 0.1 \\
\hline 5 & 1289. & $4 \cdot 5$ & 1902 & $1 \cdot \cdot 3$ & $49 \geq 3$ & $1 \cdot 5$ & 5546. & 0.5 \\
\hline 6 & 1345. & $5 \cdot 2$ & 2031 . & $1 \cdot 8$ & 5409 & $1 \cdot 8$ & $\cos 5$ & 0.7 \\
\hline 7 & 1310. & $5 \cdot 8$ & 2055 & 2.3 & 5558 & $2 \cdot 0$ & $\epsilon \approx 95$ & 0.9 \\
\hline 8 & 1300 & $6 \cdot 3$ & 2038 & $2 \cdot 7$ & 5675 & $2 \cdot 1$ & $\epsilon \triangle 1 \geq$ & $1 \cdot 0$ \\
\hline 9 & $12 \epsilon 4$ & $6 \cdot 8$ & 2040 & $3 \cdot 2$ & 5814 & $2 \cdot 3$ & 6590. & $1 \cdot 2$ \\
\hline 10 & 1241. & $7 \cdot 1$ & 2022 & $3 \cdot 4$ & 5846 & $2 \cdot 4$ & $\dot{\epsilon \in 26}$ & $1 \cdot 3$ \\
\hline 11 & 1201 & 7.5 & 2006 & $3 \cdot 8$ & 5873 & $2 \cdot 5$ & $\epsilon 678$ & $1 \cdot 4$ \\
\hline 12 & 1051. & 8. 5 & 1938. & 4.6 & 5938. & $2 \cdot 8$ & $\epsilon 786$ & $1 \cdot 7$ \\
\hline 13 & S $\boldsymbol{\varepsilon} \mathbf{5}$ & $9 \cdot 3$ & 1864. & $5 \cdot 3$ & 5968. & $3 \cdot 1$ & 6247. & 1.9 \\
\hline 14 & 856. & 9.9 & 1794. & $5 \cdot 8$ & 5933. & $3 \cdot 3$ & $\operatorname{cez} 2$ & $2 \cdot 1$ \\
\hline 15 & e 10. & 10.5 & 1713. & $6 \cdot 3$ & 5887 & $3 \cdot 5$ & $\in 791$ & $2 \cdot 3$ \\
\hline 16 & 657. & $11 \cdot 5$ & 1582 . & $7 \cdot 2$ & 5829 & $3 \cdot 8$ & $\in 754$. & $2 \cdot 6$ \\
\hline
\end{tabular}


Table A-15. Economic analysis results - Atlanta

\begin{tabular}{|c|c|c|c|c|c|c|c|c|}
\hline \multirow{3}{*}{$\begin{array}{l}\text { Design } \\
\text { option }\end{array}$} & \multicolumn{4}{|c|}{ Natural gas heating } & \multicolumn{4}{|c|}{ Electric heating } \\
\hline & \multicolumn{2}{|c|}{ No $A / C^{\star}$} & \multicolumn{2}{|c|}{ With $A / C^{\star}$} & \multicolumn{2}{|c|}{ No $A / C^{*}$} & \multicolumn{2}{|c|}{ With $\mathrm{A} / \mathrm{C}^{\mathrm{k}}$} \\
\hline & $\begin{array}{c}\mathrm{NPW}^{\dagger} \\
(1975-\$)\end{array}$ & $\begin{array}{c}\mathrm{PB}^{\ddagger} \\
\text { (years) }\end{array}$ & $\begin{array}{c}\text { NPWt } \\
(1975-\$)\end{array}$ & $\begin{array}{c}P^{\ddagger} \\
\text { (years) }\end{array}$ & $\begin{array}{c}\mathrm{NPW}^{\dagger} \\
(1975-\$)\end{array}$ & 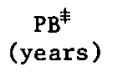 & $\begin{array}{c}\mathrm{NPW}^{\dagger} \\
(1975-\$)\end{array}$ & $\begin{array}{c}\mathrm{PB}^{\ddagger} \\
\text { (years) }\end{array}$ \\
\hline 1 & 0. & 0.0 & 0. & 0.0 & 0. & 0.0 & 0. & 0.0 \\
\hline 2 & 549 & $3 \cdot 1$ & 936. & -0.8 & 1918 & $1 \cdot 1$ & $\varepsilon \equiv 04$ & -0.3 \\
\hline 3 & 784 & $3 \cdot 9$ & 1413 & $-0 \cdot 3$ & 2886 & $1 \cdot 4$ & $3 \leqq 15$ & -0.1 \\
\hline 4 & E 14. & 4.5 & 1532. & 0.0 & 3118. & 1.6 & $3 e \geq 6$ & 0.0 \\
\hline 5 & 800 & $6 \cdot 1$ & 1391. & $2 \cdot 4$ & 3450 . & $2 \cdot 1$ & 4041. & 0.9 \\
\hline 6 & 803 & $7 \cdot 0$ & 1433 & $3 \cdot 3$ & 3755 . & 2.4 & $4 \geq 84$. & $1 \cdot 3$ \\
\hline 7 & 754 & $7 \cdot 9$ & 1425 & $3 \cdot 9$ & 3835 & $2 \cdot 7$ & 4507 & $1 \cdot 5$ \\
\hline 8 & 706. & 8.5 & 1.3 .50 & 4.6 & 3860. & $2 \cdot 9$ & 4504. & $1 \cdot 8$ \\
\hline 9 & 647. & $9 \cdot 3$ & 1318. & $5 \cdot 3$ & 3925 . & $3 \cdot 1$ & 4596 & $2 \cdot 0$ \\
\hline 10 & 619. & 9.7 & 1301. & $5 \cdot 5$ & 3939. & $3 \cdot 3$ & $\Delta \in 21$ & $2 \cdot 1$ \\
\hline 11 & 569. & 10.2 & 1270 & 5.9 & 3938 . & $3 \cdot 4$ & $4 \in 39$. & $2 \cdot 3$ \\
\hline 12 & $4 \geq 2$ & 11.6 & 1168 & 7.0 & 3923 & $3 \cdot 9$ & $4 \in 59$ & $2 \cdot 7$ \\
\hline 13 & 309. & $12 \cdot 7$ & 1068 & 8.0 & 3896. & $4 \cdot 3$ & 4655 & $3 \cdot 1$ \\
\hline 14 & 213 & 13.6 & 989. & 8.6 & 3840. & $4 \cdot 6$ & $\Delta \in I E$. & $3 \cdot 3$ \\
\hline 15 & 117 & 14.4 & 897. & $9 \cdot 3$ & 3766 : & 4.8 & $454 \epsilon$. & $3 \cdot 6$ \\
\hline 16 & $-4 s$ & 15. 8 & 745. & 10.4 & 3664 . & $5 \cdot 3$ & 4458 & $4 \cdot 0$ \\
\hline
\end{tabular}

${ }^{\star} \mathrm{A} / \mathrm{C}=$ air conditioning.

${ }^{\dagger} \mathrm{NPW}=$ net proocnt worth of savings.

${ }^{\text {F }}$ - payback periul.

Table A-16. Economic analysis results - Fort Worth

\begin{tabular}{|c|c|c|c|c|c|c|c|c|}
\hline \multirow{3}{*}{$\begin{array}{l}\text { Design } \\
\text { option }\end{array}$} & \multicolumn{4}{|c|}{ Natural gas heating } & \multicolumn{4}{|c|}{ Electric heating } \\
\hline & \multicolumn{2}{|c|}{ No $A / C^{*}$} & \multicolumn{2}{|c|}{ With $\mathrm{A} / \mathrm{C}^{*}$} & \multicolumn{2}{|c|}{ No $\mathrm{A} / \mathrm{C}^{*}$} & \multicolumn{2}{|c|}{ With $A / C^{\star}$} \\
\hline & $\begin{array}{c}\mathrm{NPW}^{\dagger} \\
(1975-\$)\end{array}$ & $\begin{array}{c}P^{\ddagger} B^{+} \\
\text {(years) }\end{array}$ & $\begin{array}{c}\mathrm{NPW}^{\dagger} \\
(1975-\$)\end{array}$ & $\begin{array}{c}\mathrm{PB}^{\neq} \\
\text {(years) }\end{array}$ & $\begin{array}{c}\mathrm{NPW}^{\dagger} \\
(1975-\$)\end{array}$ & $\begin{array}{c}\mathrm{PB}^{\text {\# }} \\
\text { (years) }\end{array}$ & $\begin{array}{c}\mathrm{NPW}^{\dagger} \\
(1975-\$)\end{array}$ & $\begin{array}{c}\mathrm{PB}^{\ddagger} \\
\text { (years) }\end{array}$ \\
\hline 1 & 0. & 0.0 & 0. & 0.0 & 0. & 0.0 & 0. & 0.0 \\
\hline 2 & 453. & 3.4 & 1080 & $-3 \cdot 3$ & 1611. & 1.2 & 22380 & -1.4 \\
\hline 3 & 609. & $4 \cdot 8$ & 1461. & -0.4 & 2378 & 1.6 & $\Xi 230$ & -0.2 \\
\hline 4 & 617. & 5.6 & 1580. & -0.1 & 2546 & $1 \cdot 9$ & 3509. & -0.0 \\
\hline 5 & $\leq \geq 0$. & 7.8 & 1382 & 2.1 & 2652 & $2 \cdot 6$ & $\equiv \Xi 14$. & 0.9 \\
\hline 6 & $5 \mathrm{ce}$ & 8. 8 & 1419 & $3 \cdot 1$ & 2894 & $3 \cdot 0$ & $3 e 04$ & $1 \cdot 3$ \\
\hline 7 & 443 & 9.9 & 1422 & $3 \cdot 7$ & 2929. & $3 \cdot 3$ & 3908 & $1 \cdot 6$ \\
\hline 8 & $3 \varepsilon 2$ & 10.8 & 1361 . & $4 \cdot 4$ & 2912 & $3 \cdot 6$ & 3891 & 1.9 \\
\hline 9 & 309. & $11 \cdot 8$ & 1320 & 5.1 & 2940 & 4.0 & 3951• & $2 \cdot 2$ \\
\hline 10 & 277. & $12 \cdot 2$ & 1307 & $5 \cdot 3$ & 2941. & $4 \cdot 1$ & 3971 . & $2 \cdot 3$ \\
\hline 11 & $2 \approx 1$. & 12.9 & 1283 & 5.7 & 2923 & $4 \cdot 3$ & 3985. & 2.5 \\
\hline 12 & 71. & 14.6 & $11 \mathrm{B9}$ & $6 \cdot 8$ & 2866 & 4.9 & 3685. & 3.0 \\
\hline 13 & $-\epsilon 5$ & 16.1 & 1093 & $7 \cdot 8$ & 2805 & 5.4 & $\geq 9 \in \Xi$ & 3.4 \\
\hline 14 & $-1 \in 6$ & 17.1 & 1022 & 8.4 & 2734 & 5.7 & 3922 & $3 \cdot 7$ \\
\hline 15 & -265 & 18.2 & 923 & 9.1 & 2651 . & $6 \cdot 1$ & $\geq e \geq 9$ & 4.0 \\
\hline 16 & -439. & 19.9 & 778 & 10.2 & 2527 & $6 . ?$ & 2742 & $4 \cdot 5$ \\
\hline
\end{tabular}

${ }^{\star} \mathrm{A} / \mathrm{C}=$ air conditioning.

${ }^{+}$NPW $=$net present worth of savings.

${ }^{*} \mathrm{~PB}=$ payback period. 
Table A-17. Economic analysis results - Phoenlx

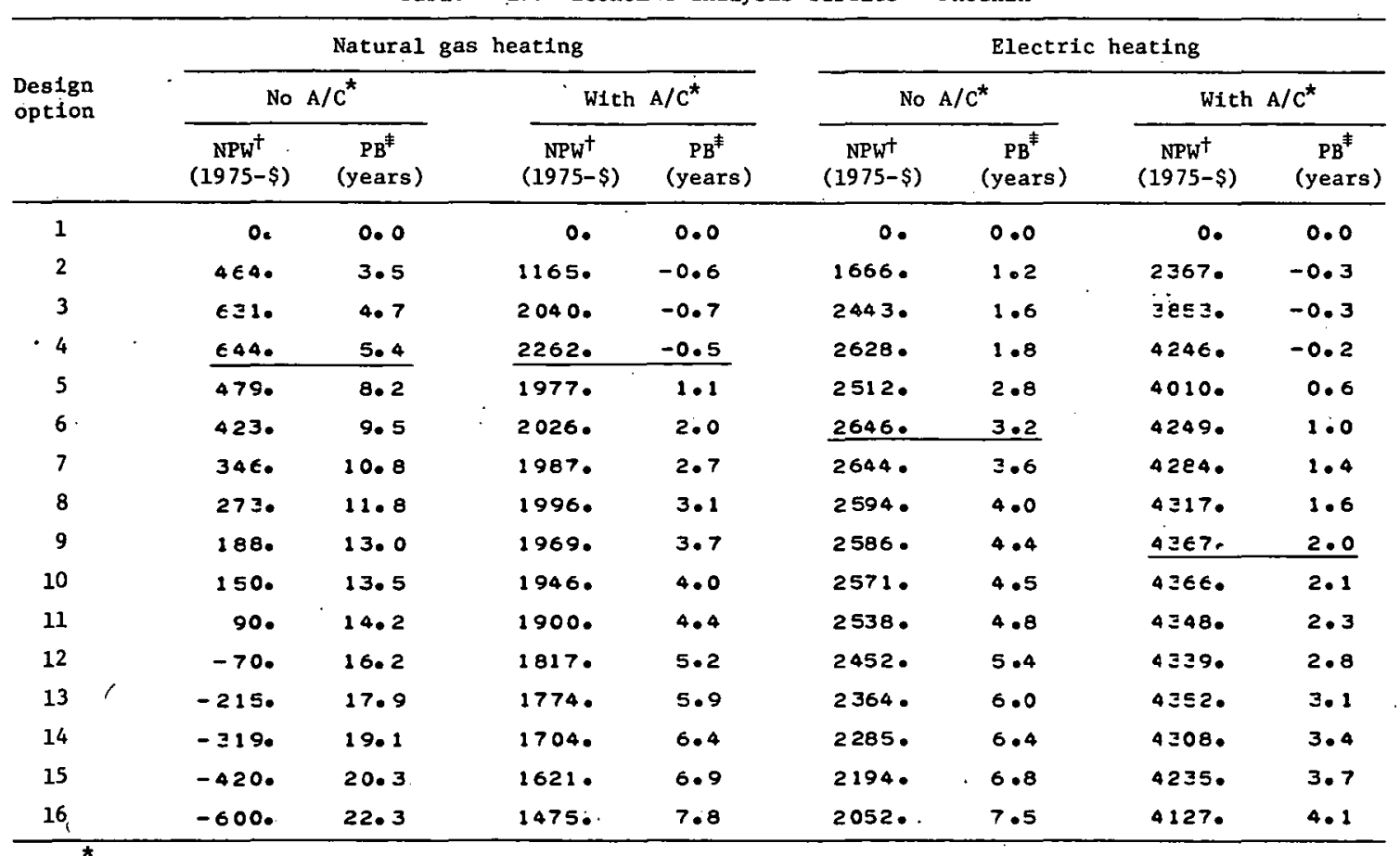

${ }^{\star} \mathrm{A} / \mathrm{C}=$ alr conditioning.

$t_{\mathrm{NPW}}=$ net present worth of savings.

${ }_{\mathrm{PB}}^{*}=$ payback period.

Table. A-18. Economic analysis results - Miami.

\begin{tabular}{|c|c|c|c|c|c|c|c|c|c|}
\hline \multirow{3}{*}{$\begin{array}{l}\text { Design } \\
\text { option }\end{array}$} & \multicolumn{5}{|c|}{ Natural:gas heating. . } & \multicolumn{4}{|c|}{ Electric heating } \\
\hline & \multicolumn{2}{|c|}{ No $A / C^{\star}$} & & \multicolumn{2}{|c|}{ Wtith $A / C^{*}$} & \multicolumn{2}{|c|}{ No $\cdot A / C^{\star}$} & \multicolumn{2}{|c|}{ With $A / C^{*}$} \\
\hline & $\begin{array}{c}\mathrm{NPW}^{\dagger} \\
(1975-\$)\end{array}$ & $\begin{array}{c}\mathrm{PB}^{\ddagger} \\
\text { (years) }\end{array}$ & & $\begin{array}{c}\mathrm{NPW}^{\dagger} \\
(1975-\$)\end{array}$ & $\begin{array}{c}\mathrm{PB}^{\#} \\
\text { (years) }\end{array}$ & $\begin{array}{c}\mathrm{NPW}^{\dagger} \\
(1975-\$)\end{array}$ & $\begin{array}{c}\mathrm{PB}^{\ddagger} \\
\text { (years) }\end{array}$ & $\begin{array}{c}\mathrm{NPW}^{4} \\
(1975-\$)\end{array}$ & $\begin{array}{c}\mathrm{PB}^{\ddagger} \\
(\text { years) }\end{array}$ \\
\hline 1 & 0. & 0.0 & & 0. & 0.0 & 0. & 0.0 & 0. & 0.0 \\
\hline 2 & -81 & 35.9 & & 310. & 1.6 & 36. & $12 \cdot 3$ & 427. & $1 \cdot 3$ \\
\hline 3 & $=153$. & 48.8 & & 492. & 2.4 & -21. & $16 \cdot 6$ & 665. & 2.0 \\
\hline 4 & - $25 \varepsilon$ & $56 \cdot 3$ & & 520. & $3 \cdot 2$ & -70. & 19.1 & 708. & 2.6 \\
\hline 5 & -444 & 83. 9 & & 192. & 10.0 & -251 . & $28 \cdot 3$ & 385. & $7 \cdot 5$ \\
\hline 6 & $-5 \varepsilon \epsilon$ & 98.8 & & 106 & 12.7 & -377 & $33 \cdot 3$ & 315. & 9.5 \\
\hline 7 & -659 & $* * * *$ & & 50. & $14 \cdot 2$ & -484 & $37 \cdot 7$ & 265 & 10.7 \\
\hline 8 & $-7 e 3$ & $* * * *$ & & -34 & 16.2 & -567 & $41 \cdot 3$ & 182. & 12.2 \\
\hline 9 & -902 & $* * *$ & & -124 & 18.2 & -680 & 45.6 & 99. & 1.3 .7 \\
\hline 10 & $-\varsigma \leqslant 1$. & $* * * *$ & & -153 & 18.8 & -727 & 47.4 & 71. & $14 \cdot 2$ \\
\hline 11 & -1024 & $* * * *$ & & -199. & 19.6 & -797 & $50 \cdot 1$ & 28. & 14.9 \\
\hline 12 & -1215 & $\neq * * *$ & & -339 & $22 \cdot 2$ & -987 & $5 ? .4$ & -107 & 17.0 \\
\hline 13 & $-1 \geq 29$. & $* * * *$ & & -473 & 24.5 & -1153 & 63.6 & $-2 a 7$ & $1.8 \cdot 9$ \\
\hline 14 & $-15 \mathrm{CS}$ & $* * * *$ & & -562 & 25.9 & -1267 & 68.0 & -324. & 20.0 \\
\hline 15 & -1611 & $\neq * * *$ & & -660. & 27.6 & -1372 & $72 \cdot 1$ & -422 & 21.4 \\
\hline 16 & -1809. & $* * * *$ & 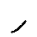 & -838 & 30.6 & -1567. & $79 \cdot 4$ & -597. & 23.7 \\
\hline
\end{tabular}

${ }^{\star} \mathrm{A} / \mathrm{C}=$ air conditioning.

${ }^{\dagger} \mathrm{NPW}=$ net present worth of savings.

${ }^{\text {* }}$ PB = payback period. 
ORNL/CON-35

\section{INTERNAL DISTRIBUTION}

1. S. I. Auerbach

2. M. Baker

3. S. E. Beal1

4. D. J. Bjornstad

5. J. R. Buchanan

6. R. S. Carlsmith

$\%$ Janet Carney

8. W. S. Chern

9. C. V. Chester

10. F. A. Creswick

11. R. M. Davis

12. J. G. Delene

13. W. Fulkerson

14. V. O. Haynes

15. N. E. Hinkle

16. E. A. Hirst

17. C. C. Hopkins

18. P. L. Johnson

19. S. I. Kaplan

20. D. Kaserman

21. R. S. Livingston

22. H. M. Long

23-42. P. M. Love

43. J. W. Miche1

44. R. E. Minturn
45. W. R. Mixon

46. J. C. Moyers

47. E. A. Nephew

48. D. L. O'Neal

49. H. Postma

50. M. W. Rosenthal

51. T. H. Row

52. R. L. Spore

53. E. G. Struxness

54. T. Takayama

55. D. B. Trauger

56. G. U. Ulrikson

57. D. J. Walukas

58. T. J. Wilbanks

59. H. E. Zittel

60. A. Zucker

61. Biology Division Library

62-63. Central Research Library

64. Document Reference Section

65-66. Energy Information Library

67. Laboratory Records, (RC)

68-70. Laboratory Records Dept.

71. ORNL Patent Office

EXTERNAL DISTRIBUTION

72. Institute of Energy Analysis, ORAU - Library

73. Research and Technical Support Division, DOE-ORO

74-101. Technical Information Center, DOE, P. O. Box 62, Oak Ridge, Temessee 37830

102-700. External Energy Conservation Distribution Mailing List and Energy Conservation Section Office (4500N, H32) 